\title{
AVALIAÇÃO EM LABORATÓRIO DA EFICIÊNCIA DE DIFERENTES FRAÇÕES GRANULOMÉTRICAS DE CALCÁRIOS AGRÍCOLAS
}

\author{
PAULO AFFONSO BELLINGIERI
}

Orientador: Prof. Dr. JOSÉ CARLOS ALCARDE

Tese apresentada à Escola Superior de Agricultura "Luiz de Queiroz", da Universidade de São Paulo, para obtenção do Título de Doutor em Agronomia. Área de Concentração: Solos e Nutrição de Plantas.

P I R A C I C A B A

Estado de São Paulo - Brasil

Março, 1983 
Aos meus pais, e avó,

\section{OFEREÇO}

A Maria do Carmo, minha esposa,

Fabiana e Paulo Henrique, meus filhos, com amor,

DE DICO 
AGRADECIMENTOS

AO PROF. DR. JOSE CARLOS ALCARDE, pela orientação e apoio.

A Escola superior de AGRICULtüra "Luiz dE QUEIROZ", pelo aperfeiçoamento concedido.

A FACULdade de ciencias agrárias e veterinArias de JABOTICABAL - UNESP, pela oportunidade desse aperfeiçoamento.

A ASSOCIAÇÃO DOS PRODUTORES DE CALCÁRIO DO ESTADO DE SÃO PAULO, pelo suporte financeiro.

AO CNPq - Conselho Nacional de Desenvolvimento Cien tífico e Tecnológico, pela bolsa de estudos concedida.

Aos colegas DR. EUCLIDES ALEXANDRINO DE SOUZA e MS EUCLIDES BRAGA MALHEIROS, pelos auxílios prestados, sugestões e manifestações de apoio.

Aos colegas que conviveram comigo no Curso de Pós-Graduação em Solos e Nutrição de Plantas, pelo auxílio, suges tões e amizade.

Ao pessoal do LABORATORIO DE QUIMICA ANALITICA DO DEPARTAMENTO DE QUIMICA da ESALQiUSP, pela colaboração prestą da nas determinações analíticas.

Aos Professores e Funcionārios do DEPARTAMENTO DE TECNOLOGIA da FCAVJ/UNESF, pelos auxílios prestados, sugestões 
e manifestações de apoio.

AO PROF. ARGEMIRO OLIVEIRA SOUZA, pelo auxílio pres tado na revisão do texto.

Às Srtas. MARLI SAES e LUIZA MARIA VILLANOVA pela datilografia e dedicação. 
INDICE

Pāgina

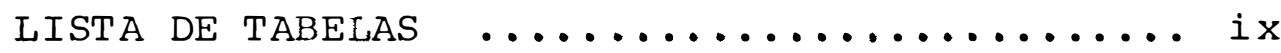

LISTA DE FIGURAS $\ldots \ldots \ldots \ldots \ldots \ldots \ldots \ldots \ldots \ldots \ldots \ldots \ldots \ldots$

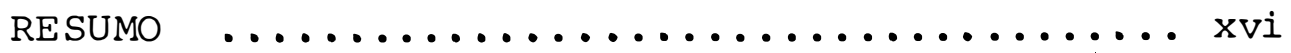

SUMMARY $\quad \ldots \ldots \ldots \ldots \ldots \ldots \ldots \ldots \ldots \ldots \ldots \ldots \ldots \ldots \ldots \ldots \ldots \ldots \ldots$

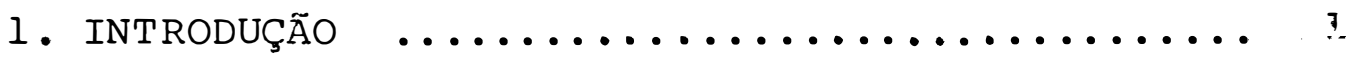

2. REVISÃO DE LITERATURA ................. 4

2.1. A acidez dos Solos ............... 4

2.2. Os Corretivos de Acidez dos Solos ...... 14

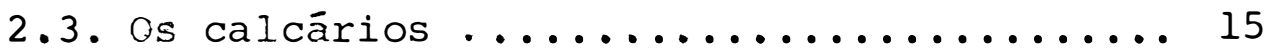

2.3.1. Conceito e Classificação ....... 15

2.3.2. Origem e Mineralogia ......... 15

2.4. Ação Neutralizante dos Corretivos e

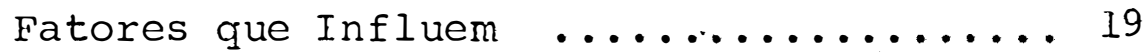

2.5. Eficiência dos Calcārios na Corre ção da Acidez de Solos .............. 2 I

2.6. Avaliação da Qualidade dos Calcá rios por Métodos Químicos ........... 32

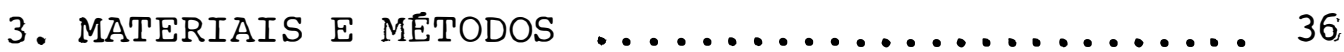

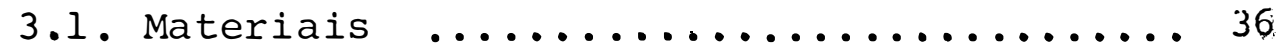

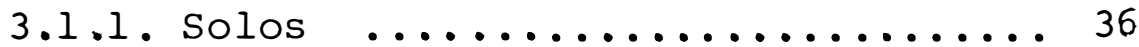

3.1.2. Corretivos $\ldots \ldots \ldots \ldots \ldots \ldots$ 
Página

3.2. Métodos .....................4 40

3.3. Delineamento Experimental ......... 42

4. Resultados e discussão $\ldots \ldots \ldots \ldots \ldots \ldots \ldots . \ldots 4$

4.1 . Valor $\mathrm{pH}$.....................4 43

4.1 .1 . Solo LVa ................4 43

4.1 .2 . Solo LEd $\ldots \ldots \ldots \ldots \ldots \ldots \ldots .46$

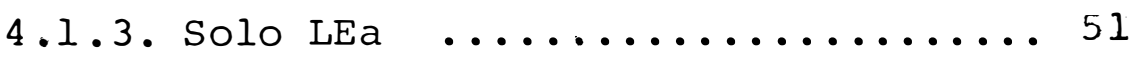

4.2. Teor de $\mathrm{Al}^{3+} \ldots \ldots \ldots \ldots \ldots \ldots \ldots \ldots$

4.2 .1 . Solo $\operatorname{LVd} . \ldots \ldots \ldots \ldots \ldots \ldots \ldots .54$

4.2 .2 . Solo LEd $\ldots \ldots \ldots \ldots \ldots \ldots \ldots . \ldots 58$

4.2.3. Solo LEa $\ldots \ldots \ldots \ldots \ldots . . . . .61$

4.3. Teor de $\mathrm{Ca}^{2+}, \ldots \ldots \ldots \ldots \ldots \ldots \ldots \ldots 6 . \ldots \ldots$

4.3.1. Solo LVd ................ 65

4.3.2. Solo LEd $\ldots \ldots \ldots \ldots \ldots \ldots \ldots \ldots 6$

4.3.3. Solo LEa $\ldots \ldots \ldots \ldots . . . \ldots . . .71$

4.4 . Teor de $\mathrm{Mg}^{2+} \ldots \ldots \ldots \ldots \ldots \ldots \ldots \ldots \ldots$. 5 .

4.4.1. Solo LVd ................. 75

4.4.2. Solo LEd $\ldots \ldots \ldots \ldots \ldots \ldots \ldots$. 28

4.4.3. Solo LEa $\ldots \ldots \ldots \ldots \ldots \ldots \ldots . .61$

4.5. Estudo das Interaçōes entre Solos, Cal cários e Frações Granulométricas ..... 84

4.6. Estimativa da Eficiência Relativa das

Erações Granulométricas............ 85 
Pägina

5. CONCLUSÕES ............................. 89

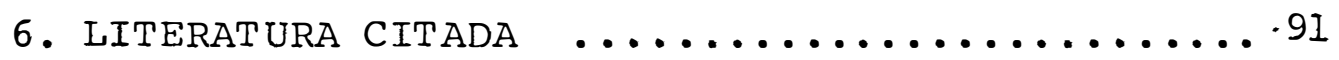


LISTA DE TABELAS

TABELA

01 Equivalente em carbonato de cálcio dos diferentes constituintes - neutralizantes dos corretivos

02

Estimativas da eficiência de diferen tes frações granulomētricas de calcá

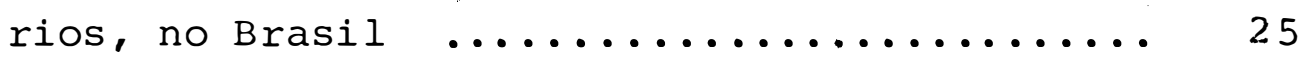

03 Classificação dos solos utilizados

04 Características físicas e químicas da camada de 0-30 cm dos trēs solos, LVd, LEd, LEa, antes da incubação

05 Teores de ōxidos de cālcio e de magnê sio nas diferentes frações granulomé tricas dos calcários estudados ...........

06 Variação do pH do solo LVd, em função do tempo de incubação (média de 4 repe

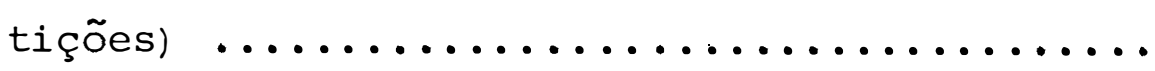


Valores de $F$ da equação de regressão de 19, 29 ou 39 grau, referentes à variação do $\mathrm{pH}$, teores de $\mathrm{Ca}^{2+}, \mathrm{Mg}^{2+}$ e $\mathrm{Al}^{3+}$ em fun ção do tempo de incubação

08

Variação do pH do solo LEd, em função do tempo de incubaçãc (média de 4 repetições) ...

Variação do pH do solo LEa, em função do tempo de incubação (média de 4 repetiçōes)

Variação do teor de $\mathrm{Al}^{3+}$, do solo LVd, em função do tempo de incubação (média de 4 repetições)

11 Variação do teor de $\mathrm{Al}^{3+}$, do solo LEd, em função do tempo de incubação (média de 4 repetições : $\ldots . \ldots \ldots \ldots \ldots \ldots \ldots \ldots \ldots . . \ldots \ldots$

12 Variação do teor de $\mathrm{Al}^{3+}$, do solo LEa, em função do tempo de incubação (média de 4 repetições ) $\ldots \ldots \ldots \ldots \ldots \ldots \ldots \ldots \ldots \ldots \ldots$

13 Variação do teor de $\mathrm{Ca}^{2+}$, do solo LVd, em função do tempo de incubação (média de 4 repetições) 
Variação do teor de $\mathrm{Ca}^{2+}$, do solo LEd, em função do tempo de incubação (média de 4 repetições) ......................... 69.

Variação do teor de $\mathrm{Ca}^{2+}$, do solo LEa, em função do tempo de incubação (média de 4 repetições

Variação do teor de $\mathrm{Mg}^{2+}$, do solo LVd, em função do tempo de incubação (média de 4 repetições 76

Variação do teor de $\mathrm{Mg}^{2+}$, do solo LEd, em função do tempo de incubação (média de 4 repetições )

18

Variação do teor de $\mathrm{Mg}^{2+}$, do solo LEa, em função do tempo de incubação (média de 4 repetições:

Eficiência relativa $\left(\frac{0}{0}\right)$ das diferentes frações granulométricas dos calcários nos vārios solos, após 12 semanas de incuba ção 
Sugestões para as eficiências relativas (ER \%) obtidas para as diferentes fra ções granulométricas dos calcários (mé dia de 4 repetições) $\quad \ldots \ldots \ldots \ldots \ldots \ldots \ldots \ldots$ 


\section{LISTA DE FIGURAS}

FIGURAS

pāgina

1 a 3

Relação dada pela equação de regressão 1 i near, entre $\mathrm{pH}$ e quantidades de $\mathrm{CaCO}_{3} \mathrm{p} \cdot \mathrm{a}$. (mg/50 g solo), determinado por incubação ... 41

4 a 7 Representação grāfica da equação de re gressão polinomial do pH em função do tem po de incubação, no solo LVd com os qua tro tipos de calcários ...............4 47

8 a 11 Representação gräfica da equação de re gressão polinomial do pH em função do tem po de incubação, no solo LEd com os qua tro tipos de calcários ................ 50

12 a 15 Representação grāfica da equação de re gressão polinomial do pH em função do tem po de incubação, no solo LEa com os qua tro tipos de calcārios ................ 53

16 a 19 Representação grāfica da equação de re gressão polinomial do $\mathrm{Al}^{3+}$ em função do tem po de incubação, no solo LVd com os qua 
FIGURAS

20 a 23 Representação gráfica da equação de re gressäo polinomial do $\mathrm{Al}^{3+}$ em função do tempo de incubação, no solo LEd com os quatro tipos de calcários .............. 60

24 a 27 Representação gráfica da equação de re gressão polinomial do $\mathrm{Al}^{3+}$ em funçäo do tempo de incubação, no solo LEa com os quatro tipos de calcários

28 a 31 Representaçäo gráfica da equação de rẹ gressão polinomial do $\mathrm{Ca}^{2+}$ em função do tempo de incubação, no solọ LVd com os quatro tipos de calcários .............6 67

32 a 35 Representação gráfica da equação de re gressão polinomial do $\mathrm{Ca}^{2+}$ em função do tempo de incubação, no solo LEd com os quatro tipos de calcários ............. 70

36 a 39 Representação gráfica da equação de re gressão polinomial do $\mathrm{Ca}^{2+}$ em função do 
FIGURAS

tempo de incubação, no solo LEa com os quatro tipos de calcários ............... 73

40 a 43 Representação gräfica da equação de re gressão polinomial do $\mathrm{Mg}^{2+}$, em função do tempo de incubação, no solo LVd com os quatro tipos de calcários ...............77

44 a 47 Representação gräfica da equação de re gressão polinomial do $\mathrm{Mg}^{2+}$, em função do tempo de incubação, no solo LEd com os quatro tipos de calcários ............... 80

48 a 51 Representação gräfica da equação de re gressão polinomial do $\mathrm{Mg}^{2+}$, em função do tempo de incubação, no solo LEa com os quatro tipos de calcärios $\ldots \ldots \ldots \ldots \ldots . \ldots . . .83$ 


\title{
AVALIAC_ÃO EM LABORATÓRIO DA EFICIẼNCIA DE DIFERENTES FRACí̃ES GRANULOMÉTRICAS DE CALCÁRIOS AGRÍCOLAS
}

\author{
Autor: Paulo Affonso Bellingieri \\ Orientador: Dr. José Carlos Alcarde
}

\section{RES U MO}

O objetivo desta trabalho foi estabelecer, em con dições de laboratório, valores para as eficiências de quatro fra ções granulométricas, de quatro calcários agrícolas, dois se dimentares e dois metamörficos, ieparados nas frações retidas entre as peneiras no (ABNT), 5-10, 10-30, 30-50 e 50-60, em três solos cobertos com vegetação de cerrado, com diferentes propriedades físicas e químicas, provenientes de Brasilia(DF) LVã e LEd e Assis(SP) - LEa.

O cālculo das doses de calcários foi baseado na curva de neutralização dos solos $\operatorname{com} \mathrm{CaCO}_{3}$ p.a., ou seja, quantidade necessária para elevar $\circ \mathrm{pH}$ a 6,5 , em um período de 40 dias.

Os solos foram incubados com as doses de calcário 
estabelecidas pela curva de neutralização por 160 dias e no 89, 16\%, 32\%, 48\%, 64\%, 80\%, 969, 1289 e 160\% dia analisados quimicamente $\left(\mathrm{pH}, \mathrm{Ca}^{2+}, \mathrm{Mg}^{2+} \mathrm{e} \mathrm{Al}^{3^{+}}\right)$.

Os dados obtidos permitiram concluir que:

1 - a reatividade dos calcários nos três tipos de solo independe da natureza geológica do calcários;

2 - a reação dos calcários varia nos diferentes tipos de solo;

3 - Sugerem-se os seguintes valores para a efi ciência relativa de diferentes frações granulométricas de cal cários: fração maior do que 10 (no de peneira $-A B N T$ ) $=0 \%$; de 10 a $30=35 \%$; de $30-50=75 \%$ e menor do que $50=100 \%$.

Assim, a expressão para o cálculo do PRNT dos cal cārios seria:

$\mathrm{PRNT}=$

$$
\therefore \mathrm{E}_{\mathrm{CaCO}_{3}}\left(\mathrm{~A}_{10-30} \times 0,35+\mathrm{A}_{30-50} \times 0,75+\mathrm{A}_{<50} \times 1,0\right)
$$

onde,

${ }_{-}^{\circ} \mathrm{CaCO}_{3}=$ porcentagem de óxidos de cálcio e de magnésio, expres sa em equivalente de $\mathrm{CaCO}_{3}$.

${ }_{10-30}=$ porcentagem da fração retida entre as peneiras 10 e 30 . A $_{30-50}=$ porcentagen da cração retida entre as peneiras 30 e 50 . $\mathrm{A}<50=$ vorcentagem da fração que passa na peneira 50 


\title{
EVALUATION IN LABORATORY OF THE EFFECTIVENESS OF DIFFERENT GRANULOMETRIC FEACTIONS OF AGRICULTURAL LIMESTONES
}

\author{
Author: Paulo Affonso Bellingieri \\ Adviser: Prof. Dr. José Carlos Alcarde
}

\section{$S \cup M M A R Y$}

The aim of this work was to establish, in laboratory conditions, the values of effectiveness of four granulometric fractions of four types of agricultural limestones, two of them of sedimentary origin and two metamorphic, divided in the fractions retained between the sieves no (ABNT) 5-10, 10-30, 30-50 and 50-60 and incubated in three types of soils covered with "cerrado" vegetation with different physical and chemical properties, from the region of Brasilia(DF) - LVd and LEd and Assis region (SP) - LEa.

The calculation of the doses of limestones were based on the neutralization curve of the soils with $\mathrm{CaCO}_{3}$ p.a., or the necessary quantity to raise the pH to 6,5 , during a period of 40 days.

The soils were incubated with the doses of Iimestones, established by the neutralization curve, during 160 
days in the $8^{\text {th }}, 16^{\text {th }}, 32^{\text {nd }}, 48^{\text {th }}, 64^{\text {th }}, 80^{\text {th }}, 96^{\text {th }}, 128^{\text {th }}$ and $160^{\text {th }}$ days and chemically analysed ( $\mathrm{pH}, \mathrm{Ca}^{2+}, \mathrm{Mg}^{2+}$ and $\left.\mathrm{Al}^{3+}\right)$.

The results obtained allowed to conclude that:

1 - The reactivity of the limestones in the three types of soil is not dependent upon the geological nature of: the limestones.

2. The reaction of the limestones varies in the types of soil.

3 - The following values for the relative effi ciency of the different granulometric fractions of the limes tones are suggested: fractions larger than 10 (no sieve - ABNT) $=0 \%$, from 10 to $30=35 \%$, from 30 to $50=75 \%$ and less tham $50=100 \%$

Then, the expression for the calculation of RPTN of limestone would be:

$\operatorname{RPTN}={ }^{\left.\stackrel{\circ}{a} \mathrm{CaCO}_{3}{ }^{\left(A_{10-30}\right.} \times 0,35+A_{30-50} \times 0,75+A_{<50} \times 1,0\right)}$

where:

${ }^{\circ} \mathrm{E}_{\mathrm{CaCO}_{3}}=$ percentual of calcium and magnesium oxides expressed in equivalent of $\mathrm{CaCO}_{3}$.

$\mathrm{A}_{10-30}=$ percentual of retained fraction between the sieves 10 and 30 .

$\mathrm{A}_{30-50}=$ percentual of retained fraction between the sieves 30 and 50 .

$A_{<50}=$ percentual of the fraction that passes through sieve 50 . 
1. INTRODUÇÃO

o estudo do problema da acidez do solo assume cada vez mais interesse face ao aumento da importância da necessi dade de sua correção, para obtenção de boas colheitas. . Por outro lado, não se dispõe ainda de parāmetros suficientemente seguros para avaliar a qualidade dos calcários, materiais mais comumente usados nessa correção.

Os calcários variam geralmente quanto às caracte rísticas mineralógicas, composição química e propriedades fí sico-químicas. A capacidade total na neutralização do solo é determinada pelos teores de carbonato de cálcio e magnésio, do material calcário. Porēm, a rapidez de reação desses nate riais depende tambēm do estado de divisão ou grau de finura. Portanto, a reatividade no solo, das diferentes rochas calcā rias moídas, está condicionada ao poder neutralizante e à gra nulometria. Por outro lado, as características mineralógicas e a textura têm sido indicados, por hipótese, como elementos de influência na solubilidade desses materiais, podendo deter 
minar variações de ação, ainda que se apresentem com a mesma composição química e granulométrica, já que lhes conferem pro priedades diferentes.

A diminuição do diâmetro das partículas e conseqthen te acréscimo da superfïcie de exposição, traduz-se num aumen to de solubilidade. Por outro lado, para um mesmo grau de fi nura, a rapidez da reação poderia variar com o tipo de calcá rio.

No Sul do País, os calcărios vêm sendo avaliados pelo PRNT(Poder Relativo de Neutralização Total), o qual é um Indice que mede a eficiência de calcários,conjugando o poder de neutralização total com a eficiência relativa das partícú las de diferentes tamanhos. O cálculo do PRNT feito no sul adota valores de Eficiência utilizados nos Estados Unidos da América do Norte, isto é, o valor zero para partículas retí das na peneira no 10, 20\% para partículas retidas entre pene $\underline{i}$ ras 10 e $20,60 \%$ para particulas retidas entre as peneiras 20 e 60 e $100 \%$ para partículas que passam na peneira 60 .

A legislação brasileira atual, Lei no 6.894 e res pectivos decretos e portarias, estabelece que os corretivos de acidez do solo devem conter $100 \%$ das partículas com diâme tro inferior a $2,00 \mathrm{~mm}$ (peneira no 10-ABNT) e no mínimo 50\% das partículas com diâmetro inferior a $0,300 \mathrm{~mm}$ (peneira no $50-\mathrm{ABNT}$ ) .

A eficiência relativa das diferentes frações granu 
lométricas dos calcărios fundamenta-se na velocidade de sua reação com o solo. Portanto, essa eficiência deve ser depen dente também das características do solo e do clima, além das características dos calcários. Assim, a simples transferên cia de valores de eficiência estabelecidos de uma região para outra pode ser constestada. Essa suposição constitui a hipótese do presente trabalho, cujo objetivo foi estudar, em condi ções de laboratório, o estabelecimento da eficiência de qua tro frações granulométricas de quatro calcários agrícolas em função de três solos de diferentes propriedades físicas e quí micas. 
2. REVISÃO DE LITERATURA

2.1. A Acidez dos Solos

Os fatores que limitam o rendimento das plantas cul tivadas são vários e o efeito de cada um, ou de suas intera ções, estão condicionados aos diferentes tipos de solos, às condições ambientais da região considerada e às plantas em cul tivo. Além disso, o nümero de propriedades do solo, alteradas, quando o pH é corrigido, dificultam a definição pelo fator, ou pelos fatores interrelacionados, mais responsáveis pela bai xa fertilidade dos solos ácidos (JACKSON, 1967). Mesmo assim, a toxidez do alumínio e do manganês e as deficiēncias de căl cio, magnésio e fósforo são mais comumente constatadas nesses solos (JACKSON, 1967 e KAMPRATH, 1967).

$\mathrm{O} \mathrm{pH}$ do solo, que expressa a atividade dos ions hi drogênio na solução do solo, é a representação analíti ca comumente medida e a este se relacionam a disponibi lidade, deficiência ou toxidez dos elementos, sendo constata do que, quanto mais baixo seu valor, mais limitantes se tornam 
as condições de fertilidade do solo (JACKSON, 1967). Entretanto, a extensão da sua influência não está suficientemente es clarecida.

A acidez do solo, no século passado, era atribuída à presença de ácidos hưmicos. Porém, em 1904 Veitch, conforme JENNY (1961), mostrou que em solos com baixos teores de húmus a causa da acidez seria o alumínio extraível com cloreto de só dio. Posteriormente, surgiram vărias teorias sobre a natureza da acidez dos solos, ora destacando o alumínio como a causa, ora atribuindo a acidez ao hidrogênio trocável. Mais tarde, foi aceita a idéia da ocorrência do alumínio e hidrogênio em solos ácidos. Em 1946, Schofield, ainda segundo o relato' de JENNY (1961), estimulou o reconhecimento do alumínio como par ticipante na troca de cátions nos solos ácidos, postulando a existência de íons $\mathrm{H}_{2} \mathrm{O}-\mathrm{OH}-\mathrm{Al}$. Polímeros do alumínio, coordena dos octaedricamente, de alta valência e que poderiam ser titú lados com bases.

JACKSON (1963) atribuiu ao alumínio trocável e às formas polimerizadas do alumínio, o principal papel na acidez da fração mineral do solo.

COLEMAN (1962) relata que a origem do alumínio em solos ácidos è devida: (a) à instabilidade das argilas satura das com hidrogênio, que se decompoem e liberam-no da rede crís talina; e (b) à afinidade de adsorção do íon alumínio com os sitios de troca das argilas.

Em soluções àcidas, o alumínio ocorre como um cá 
tion trivalente complexo, onde cada ion $\mathrm{Al}^{3+}$ está envolvido por seis moléculas de $\mathrm{H}_{2} \mathrm{O}$ em coordenação, formando o $\mathrm{A}_{1}\left[\left(\mathrm{H}_{2} \mathrm{O}\right)_{6}\right]^{3+}$ (MCLEAN, 1965), denominando alumínio hexahidrônio

(JACKSON, 1963). Quando o pH aumenta, uma ou duas medidas de água perdem $\mathrm{H}^{+}$, ou uma ou duas moléculas de água são substituídas por íons $\mathrm{OH}^{-}$, formando radicais mono e divalentes (MCLEAN, 1965). São os polímeros dos hidrōxidos parciais de alumínio, de tamanho e grau de hidratação indefinidos, que juntamente com o alumínio trivalente monomérico, são adsorvidos pelos sítios de troca das argilas (THOMAS, 1960; COLEMAN \& THOMAS, 1967 e LEOON, 1971).

Essas formas de ligações do alumínio que, aparente mente, estão em equilíbrio em solos ācidos (HEDDLESON et a $\imath_{i} i$, 1960), compõem a principal fonte de acidez da fração mineral do solo. Porém, a extensāo de sua contribuição depende: (a) do grau de intemperismo do solo, dado aparentemente pelo teor de alumínio trocável (COLEMAN, 1962 e HEDDLESON et alii, 1960); (b) do pH, que é a expressão da atividade dos íons hidrogênios (YUAN, 1963); e (c) do teor de matéria orgânica, o componente äcido-fraco dos solos (THOMAS, 1960; COLEMAN \& THOMAS, 1967 e LEON, 1971).

Solo ácido tem sido definido como um sistema capaz de liberar protons ou aceitar $\mathrm{OH}^{-}$(JACKSON, 1963). E observado quando o pH é inferior a 7,0 e/ou a capacidade de troca de cá tions não está preenchida por cátions básicos (COLEMAN e THO MAS, 1967). Este sistema é constituído pelos fatores de acidez 
que controlam a troca de ions e as reações de adsorção, que de finem o caráter ācido dos solos.

As formas de acidez dos solos parecem ter a seguin te ordem de atividade: cargas permanentes ocupadas pelo $\mathrm{H}^{+}>$ cargas permanentes ocupadas pelo $\mathrm{Al}^{3+}$; monômeros de hidrōxidos de aluminio $\left(\mathrm{AlOH}^{2+}\right)$; polímeros dos hidróxidos de alumínio acidez da matéria orgânica $\simeq$ acidez do $\mathrm{Al}-\mathrm{OH}$ e $\mathrm{Si-OH}$ da rede cristalina (JACKSON, 1963; MCLEAN et alii, 1964 e COLEMAN e THOMAS, 1967). As duas primeiras formas ocupam parte da capaci dade de troca de cátions permanente ou "efetiva", e constituem, a acidez de troca. As quatro ũltimas compõem a acidez pH-depen dente.

Não se conhece exatamente o mecanismo de neutraliza çäo da acidez, mas presume-se que, quando as reações de neutra lização iniciam-se no solo, provavelmente primeiro são neutra lizadas as formas mais ativas, $\mathrm{H}^{+}$e $\mathrm{Al}^{3+}$ (KENNEY e COREY, 1963; KAMPRATH, 1970 e LEON, 1971). Os Ions $\mathrm{H}^{+}$seriam neutraliza dos ainda antes das reações do alumínio com a base (YUAN, 1963).

O alumínio trivalente monomérico se hidroliza na so Iução, produzindo: $\mathrm{Al}^{3+}+\mathrm{H}_{2} \mathrm{O} \rightarrow \mathrm{AlOH}^{2+}+\mathrm{H}^{+}$. Possivelmente os produtos dessa hidrólise sejam readsorvidos pelas argilas (RAGLAND e COLEMAN, 1960; FRINCK e PEECH, 1963 e JACKSON, 1963), desenvolvendo cargas aparentemente pH-dependentes, ou seja, ina tivando sítios de troca pela adsorção ou obstrução destes (CO LEMAN et alii, 1964 e COLEMAN e THOMAS, 1967), ou ainda, reco brindo os cristais de argila na forma de $\left.A{ }^{(O H}\right)_{x}$ (RAGLAND e CO 
LEMAN, 1960)

MOHR (1960), KAMPRATH (1967) e REEVE e SUMMER (1970) apontam o alumínio trocável como o principal responsável pelo baixo rendimento das plantas cultivadas em solos com pH infe rior a 5,0 e VOLKWEISS (1970) atribui-lhe, e ao manganès, os baixos rendimentos obtidos com culturas em solos brasileiros. A presença de alumínio e manganês trocáveis no solo implica no decréscimo de absorção de cálcio e tem efeitos prejudiciais no crescimenta. das raízes (KAMPRATH, 1967).

Estudos sobre o efeito da acidez e calagem no rendi mento de plantas cultivadas asseguram que os rendimentos máxí mos foram alcançados quando os teores de alumínio e manganês trocáveis reauziram-se atē quantidades não tóxicas (ABRUÑ̃, et a Iii, 1970; REEVE e SUMNER, 1970; VOLKWEISS, 1970; WHITE, 1970 e VIDOR, 1972), embora em alguns casos o pH tenha atingi do valores próximos a 7,0 e, em outros, pouco ultrapassado a 5,0. COLEMAN e THOMAS (1967) observaram que elevando o pH do solo até valores em torno de 5,5 o alumínio trocável deixava de ser tóxico às plantas e o manganês diminuía consideravelmen te seu efeito nocivo äs plantas ensaiadas. BORKERT(1973) rela tou, para alguns solos do Rio Grande do sul e Santa Catarina, que em valores de $\mathrm{pH} 6,0$ e 6,5 ainda eram encontrados teores de manganês considerados tóxicos (24 ppm) para plantas cultiva das.

Por essa razão, torna-se difícil estabelecer o pH ideal para o máximo rendimento das plantas cultivadas, ou mes 
mo onde cessam as limitações e/ou os efeitos nocivos dos ele mentos tóxicos comuns em solos àcidos. Contribui para isso tam bém o fato de que existem diferenças na tolerância, pelas espé cies, aos elementos nocivos, assim como também variação na cạ pacidade de extrair os elementos indispensáveis do solo (JACKSON, 1967).

No Brasil, āreas enormes, muitas delas de importân cia agrícola das mais elevadas, são ocupadas por solos áci dos. Somente os solos ácidos de cerrado ocupam uma área de 1,6 milhões de $\mathrm{km}^{2}$, ou seja, $1 / 5$ da superfície total do país MISSÃO DE SOLOS, 1960).

GARGANTINI et alii (1965) concluíram que aproximada mente 50\% da área cultivada do Estado de são Paulo apresenta problemas de acidez elevada, sendo aconselhável o emprego de corretivos. Tal emprego, porém, atinge caráter obrigatório, pa ra que se possa obter colheitas elevadas em cerca de $20 \%$ da ārea sob cultivo neste Estado, devido aos teores inconvenien tes de alumínio trocável.

A necessidade de calagem em áreas agrícolas deste Paîs é, pois, um fato reconhecido e que não necessita discus são. Mas, entre os problemas ainda pendentes de solução en contra-se o que diz respeito aos métodos de determinação das quantidades de calcário a serem aplicadas.

De uma forma geral, a determinação da acidez poten cial em solos constitui o principio dos métodos de indicação das quantidades de corretivos dos solos (MCLEAN et a $i$ i , 1959). Assim, 
a quantidade de base consumida para medir a acidez de um solo, por um determinado método, corresponde, aproximadamente, à ne cessidade de corretivo do solo analisado, para atingir um $\mathrm{pH}$ pré-estabelecido.

FREITAS et alii (1968) subdividem os métodos de de terminação de necessidade de calagem dos solos em dois grupos: um que consiste em prever a quantidade de calcário para elevar o pH do solo até uma faixa de valores pré-fixada;outro, que preve calcário para neutralizar o alumínio trocável e assegurar o $\underline{\text { u }}$ primento de cálcio e magnésio para as plantas, independente dos valores de $\mathrm{pH}$ que alcançaria o solo. o último emprega so luções de sais não tamponados, medindo a acidez de troca dos solos e, consequentemente, a necessidade de calcário para sua neutralização (KAMPRATH, 1967) .

Os métodos de determinação de necessidade de calcā rio de solos têm sido testados mediante comparação com os re sultados obtidos pela incubação do solo com carbonato de cál cio até atingir um valor de $\mathrm{pH}$ de equilíbrio. Também têm sido conduzidos estudos para correlacionar a necessidade de calagem com o teor de alumínio trocável dos solos e rendimento dos cul tivos, independente dos valores de $\mathrm{pH}$ que o solo alcance.

FREITAS et alii (1968) observaram que o método ba seado na acidez extraída com cloreto de potássio e no suprí mento de cálcio e magnésio ao solo mostrou-se satisfatório, tanto para neutralizar o aluminio trocável como para suprir as culturas de cálcio e magnésic dando, porēm, baixa coxrelação, 
embora significativa, com os valores de necessidade de correti vos para controle do $\mathrm{pH}$ determinados pela incubação.

KAMPRATH (1970) trabalhando com Oxisol e Ultisol dos E.U.A. e REEVE e SUMNER (1970), usando Oxisol de Natal, na Africa, questionam a elevação do $\mathrm{pH}$ dos solos até 6,5 . Os auto res observam que, nesses solos, o uso de calcário em quantida des suficientes para eliminar o aluminio trocável tem dado re sultados satisfatörios no rendimento das plantas cultivadas.

MOHR (1960) e KAMPRATH (1970) sugerem o emprego do fator 1,5 que, multiplicado ao valor da acidez de troca, dada em e. mg/100 g e obtida na extração com cloreto de potássio, corresponderia à necessidade de calcário do solo em toneladas por hectare. HOYT e NYBORG (1971) encontraram resultados seme lhantes aos dos autores citados e acrescentam que o cloreto de sódio 2N apresentou eficiência similar à do cloreto de potás sio na determinação da acidez de troca para indicação de corre tivos.

o uso desses métodos na determinação de acidez e ne cessidade de calcário tem limitações. Estas se relacionam com as propriedades dos extratores, com as características dos so los e com a rapidez de execução.

Continua ainda, no Brasil, a tendência de se reco mendar a quantidade de corretivo a ser distribuida numa deter minada área, tomando-se por base o teor de $\mathrm{Al}^{3+}$ trocável do so Io, seguindo o conceito de que o importante é a neutralização da acidez causada por esse elemento e o fornecimento de cálcio 
e magnésio às plantas (KAMPRATH, 1967 e KAMPRATH, 1970). Contü do, não existe experimentação adequada a esse respeito e, no Rio Grande do Sul, em várias situações, tem-se verificado que as quantidades de calcário recomendadas de acordo com o métó do referido são muito pequenas.

\section{MUZILLI et alii (1969), por exemplo, utilizando}

método de incubação de amostras de terra com quantidades cres centes de $\mathrm{CaCO}_{3}$, concluirram que, em relação aos cinco latos sóis roxos estudados, as quantidades de $\mathrm{CaCO}_{3}$, em toneladas, $\left(Q=1,5 \times\right.$ no de e. Mg $\mathrm{Al}^{3+}$ trocável/100 g de terra) eram suf $\underline{i}$ cientes para reduzir os teores deste cátion na forma trocável. a valores menores do que 0,5 e. $\mathrm{mg} / 100 \mathrm{~g}$ de terra, mesmo quan do o teor original era igual a 2,3 e.mg/100 g de terra.

o estudo conduzido nos mesmos solos, em condições de campo (MUZILLI et alii, 1969), revelou que, aos 60 dias após a aplicação, a quantidade de calcário dolomítico empregada $(29,23 \%$ de CaO e $21,36 \%$ de $\mathrm{MgO}), Q=1,5 \times \mathrm{n}$. de e.mg $\mathrm{Al}^{3+}$ tro cável/loog de terra, era suficiente para reduzir em todos os casos, o teor de $\mathrm{Al}^{3+}$ trocável a 0,5 ou menos e.mg/100 g de ter ra, correspondendo a valores $\mathrm{pH} \geqslant 5,4$. A reduçäo do teor de $\mathrm{Al}^{3+}$ trocável bem como a elevação do $\mathrm{pH}$ se tornaram mais visí veis à medida que se aumentavara as doses de calcário e o perío do de amostragem, que se prolongou até 120 dias após a incorpo ração do corretivo.

CATANI e ALONSO (1969) estudaram a exigência de cal cário de 20 amostras de solo empregando a técnica de incubação 
com quantidades crescentes de $\mathrm{CaCO}_{3} \mathrm{p} \cdot \mathrm{a}$. Os resultados obti dos serviram para testar os seguintes métodos:

a) Elevação do $\mathrm{pH}$ do solo a 6,5, mediante a extra ção de hidrogênio ou prótons, dos diversos componentes da ací dez, com solução neutra e normal de acetato de cālcio e poste rior titulação com solução $0,02 \mathrm{~N}$ de $\mathrm{NaOH}$; obteve-se um coefí ciente de correlação $r=0,92 * *$.

b) Elevar o pH do solo a 6,5, mediante extração de hidrogênio ou prótons de diversos componentes da acidez, com soluçäo tampão SMP, com pH original 7,5 e determinação poste rior do pH da suspensão do solo; obteve-se um coeficiente de correlação $r=0,90 * *$.

c) Elevaçäo do $\mathrm{pH}$ do solo a 6,5, mediante a eleva ção da porcentagem de saturação em bases a 85\%; obteve-se um coeficiente de correlação $r=0,96 *$.

d) Elevaçäo do $\mathrm{pH}$ do solo a 5,7, por meio da extra ção do alumínio trocável com solução $1 \mathrm{~N}$ de $\mathrm{KCl}$; coeficiente de correlação $=0,72 * * *$.

Atualmente, algurs pesquisadores (KAMPRATH, 1967; SANTANA, 1970) têm dado mais ênfase à porcentagem de saturação do complexo coloidal do solo em $\mathrm{Al}^{3+}$ que ao próprio teor des se elemento existente em forma trocável, ou à combinação teor de $\mathrm{Al}^{3+}$ trocável e soma dos teores de $\mathrm{Ca}^{2+}$ e $\mathrm{Mg}^{2+}$ trocáveis (SOUZA, 1970). 
2.2. Os Corretivos de Acidez dos Solos

Os materiais que podem ser usados na correção da acidez dos solos são aqueles que contêm como "componente neu tralizante" ou "princípio ativo", óxidos, hidróxidos, carbona tos e/ou silicatos de cálcio e/ou de magnésio.

O material corretivo natural mais comum é o calcā rio, existente com relativa frequência e abundância, o que jus tifica o seu maior uso universalmente. Seu componente neutrali zante é o carbonato de cálcio, normalmente associado ao carbo nato de magnésio.

Alèm do calcário, diversos outros materiais também podem ser usados como corretivos. Oxido de cálcio e/ou de mag nésio, obtidos pela calcinação de calcário, tambēm conhecidos como cal virgem e se apresentam, por natureza, como pó bastan te fino. Hidróxido de cálcio e/ou de magnésio, obtidos pela hi dratação dos óxidos de cálcio e/ou de magnésio, também conhecí dos como cai hidratada ou cal extinta; cujas características e propriedades são muito semelhantes às do óxido. Calcārio cal cinado, obtido pela calcinação parcial do calcário, onde nem todo $\circ \mathrm{CaCO}_{3}$ e $\mathrm{MgCO}_{3}$ são decompostos, é um produto intermediā rio entre o calcário e a cal. Escórias de siderurgia, sub-pro duto da indústria do ferro e do aço, cujo componente neutrali zante é o silicato de cálcio e/ou de magnésio, comportam-se se melhante ao calcário (GOMES et alii, 1962; WUTKE e GARGANTINI, 1962 e GOMES et alii, 1965) e apresentam teores relativamente 
elevados de micronutrientes, mas praticamente não têm sido usa dos. Outros materiais, como: margas (depósitos terrestres de carbonato de cálcio), calcários marinhos (corais, sambaquis) e sub-produtos de diversas indústrias, podem ser usados.

No Brasil o material mais importante como correti vos é o calcário.

\subsection{Os Calcărios}

\subsubsection{Conceito e Classificação}

Calcário è um termo geral que abrange rochas carbona tadas ou fósseis, compostas primariamente de carbonato de cál cio ou combinaçöes de carbonatos de cálcio e magnësio com quan tidades variadas de impurezas, sendo as mais comuns sílica e a a lumina.

Calcita ou aragonita contêm $100 \%$ de $\mathrm{CaCO}_{3}$ (56\% de CaO dolomita pura contêm $54,3 \%$ de $\mathrm{CaCO}_{3}$ e 45,7\% de $\mathrm{MgCO}_{3}$ (30,4\% de $\mathrm{CaO}$ e $21,9 \%$ de $\mathrm{MgO}$ ). Em função do teor de $\mathrm{MgCO}_{3}$ presente nos calcários, estes são classificados em altamente calcíticos, quando o teor de $\mathrm{MgCO}_{3}$ è baixo (não excedendo a 2-5\% ou a 12,5\% de $\mathrm{MgO}$ ); magnesiano, quando o teor de $\mathrm{MgCO}_{3}$ é de 5-20\% ou 2,5-10\% de $\mathrm{MgO})$; dolomítico, quando o teor de $\mathrm{MgCO}_{3}$ è maior do que $20 \%$ ou o de MgO maior que $10 \%$ (BOYNTON, 1965).

\subsubsection{Origem e Mineralogia}

o calcário, que é a mais importante e abundante de 
todas as rochas sedimentares, com emprego comercial e é, geral mente, de origem orgânica.

Os fossiliferos, sedimentações marinhas e de āgua doce, sāo constituídos de conchas e esqueletos de plantas e animais, gradualmente acumulados por deposição, camada sobre camada, para formar, em alguns casos, camadas maciças de rocha calcária. Alguns destes sedimentos foram depositados por rea ções químicas naturais, isto é, dissolução infinitesinal des tes fósseis de carbonato de cālcio atravēs da ação solvente do dióxido de carbono, formando bicarbonato de cālcio, o qual foi posteriormente reprecipitado na forma de carbonato. Algumas ve zes esta precipitação é indireta, por intermédio de organis mos vegetais e/ou animais. A precípitação direta de carbonato atravēs de uma solução saturada é causada por um aumento na temperatura, a qual provoca uma redução na solubilidade do car bonato de cálcio (BOYNTON, 1965).

A textura e a forma cristalina da rocha calcária de pendem do tamanho e formato das partículas ou grãos de calcā rio que são depositados normalmente. Esta deposição é contami nada por diferentes quantidades de impurezas, como silica, que através do tempo, tornam-se uma parte integrante (íntima) da rocha, cimentadas externamente por partículas de carbonato.

o sedimento calcário pode permanecer relativamente friável. ou pode ser metamorfisado atravēs de altas tem peraturas e pressão e se fundir numa forma altamente cristalina. Exemplos de rocha calcária que não são de 
origem orgânica seriam as estalactites e estalagmites em caver nas e alguns calcários aolíticos, travertina e turfa calcāria. Entretanto, a presençà de fósseis em vários graus é visível na maioria dos calcários comerciais e isto possibilita aos geólo gos determinar a era geológica da qual derivaram.

Outro constıtuinte comum da rocha calcária, o carbo nato de magnésio, é formado da mesma maneira descrita anterior mente, mas existe também uma teoria de que ele foi formado pe la troca de cálcio por magnésio a partir de sais de magnésio que estão em abundância no mar. A decomposição da serpentina (silicato de magnésio hidratado). seria uma outra origem possí vel.

Todas as autoridades geolögicas concordam que o cal cário pode ser composto de 4 minerais e ter impurezas restrí tas: Calcita $-\mathrm{CaCO}_{3}$; Aragonita $-\mathrm{CaCO}_{3}$; Dolomita $-\mathrm{CaCO}_{3} \cdot \mathrm{MgCO}_{3}$ e Magnesita $-\mathrm{MgCO}_{3}$. Nos minerais acima, há um ponto de desa cordo que é a controvérsia sobre o fato da dolomita ser um car bonato duplo de cálcio e magnésio ou uma mistura mecânica de calcita e magnesita.

Os dois tipos fundamentais de calcário são o calcí tico e o dolomítico. Calcário altamente puro (calcita ou arago nita) tem 100\% de carbonato de cálcio. Não há calcário com es ta pureza, comercialmente disponível. Para fins prăticos, calcário é considerado calcítico (alto teor de cálcio) de alta qualidade quando tem de 97 a $99 \%$ de $\mathrm{CaCO}_{3}$ e dolomítico quando tem de 40 a $43 \%$ de $\mathrm{MgCO}_{3}$, com o composto $\mathrm{CaCO}_{3}$ apresentando um 
um teor um pouco maior do que o téorico, e 1 a $3 \%$ de impurezas. Em água destilada pura que é livre de $\mathrm{CO}_{2}$ dissolvi do e numa atmosfera livre de $\mathrm{CO}_{2}$, o calcārio é virtualmente in solúvel, mas com o aumento da pressão parcial de $\mathrm{CO}_{2}$, a solu bilidade aumenta até o ponto onde pode ser caracterizado como fracamente solüvel.

A solubilidade de todos os calcários é marcadamente aumentada com aumento no incremento da pressão de $\mathrm{CO}_{2}$, e a am plitude da solubilidade torna-se progressivamente menor, com o aumento da temperatura.

Kline (1923) citado por BOYNTON (1965), calculou a taxa de solubilidade do $\mathrm{CaCO}_{3}$ a vărias temperaturas, indepen dente da pressão de $1 \mathrm{~atm}\left(25^{\circ} \mathrm{C}\right)$. Ele provou que a solubilida de decresce prontamente, assim que a temperatura è elevada aci ma de $0^{\circ} \mathrm{C}$.

O aumento das pressões parciais de $\mathrm{CO}_{2}$ tem - "mesmo efeito da magnesita, exceto que o grau de dis solução é mais pronunciado. À $19,5^{\circ} \mathrm{C}$ e à pressão de 9 atmosfé ras de $\mathrm{CO}_{2}$, observou-se uma solubilidade de $56,59 \mathrm{~g} / 1$. Desta maneira, $0 \mathrm{MgCO}_{3}$ é cerca de 15 a 20 vezes mais solúvel do que - $\mathrm{CaCO}_{3}$ em bases equivalentes, porém a dolomita é considerada como sendo apenas 2 a 3 vezes mais solúvel.

Soluções aquosas de sais de vărias concentrações afetam a solubilidade do carbonato de cálcio e magnésio de di ferentes minerais, com ou sem pressão de $\mathrm{CO}_{2}$.

Apesar dos sais, a altas concentrações, aumentarem 
a solubilidade dos calcários em 10 ou 20 vezes, em nenhum ca so o mineral carbonato torna-se realmente solüvel. Modestos au mentos na solubilidade ocorrein mesmo com concentraçoes muito diluídas, como 0,1 a $0,5 \mathrm{~g} / 1$ de soluto.

2.4. Ação Neutralizante dos Corretivos e Fatores que In fluem

A baixa solubilidade do calcário faz com que a velo cidade de neutralização da acidez dependa da ärea de contato entre o corretivo e o solo. Quanto menor a granulometria do calcārio mais rápida é a reação de neutralização (MIELNIC.zUK et alii, 1971; VERLENGIA e GARGANTINI, 1972; BOHNEN e W"UNSCHE, 1972; SOUZA E NEPTUNE, 1979 e TEDESCO e ANGHINONI, 1980).

o calcário agrícola é constituído por um contínuo de frações granulomētricas inferiores a $2,00 \mathrm{~mm}$ (a Legislą̧ão brasileira permite atẻ $50 \%$ de partículas compreendidas entre 2 e 0,3 mm - peneiras no 10 e 50 - ABNT, respectivamente). As frações mais finas do corretivo reagem maiș rapidamente, atin gindo o pH de equilíbrio no solo em pouco tempo (2 a 3 meses). Devido a este fato, GARGANTINI (1974) não detectou diferenças na efetividade entre os tratamentos de calcário que adicionou ao solo, pois todos continham as fraçōes mais finas. Em outro trabalho, VERLENGIA e GARGANTINI (1972) reconhecem que as fra ções mais finas são mais eficientes na correção da acidez.

A velocidade de neutralização depende tambëm 
teor de umidade, da temperatura, do grau de homogenei zação com o solo, e das propriedades físicas e químicas do calcário.

Para avaliar a qualidade do calcärio como corretivo da acidez è necessário estabelecer índices que expressem a ca pacidade de reação de cada fração granulométrica durante um pe ríodo de tempo determinado. A metodologia de trabalho mais indicada é a descrita por LOVE et alii (1960), necessitando se paração das diversas frações do corretivo, adição ao solo em quantidades variáveis de cada uma e avaliação dos elementos da acidez do solo por 3-5 anos.

Alguns trabalhos de incubação em laboratório ou ca sa - de - vegetação têm sido realizados (BOHNEN e wÜNSCHE, 1972; VERLENGIA e GARGANTINI, 1972; TEDESCO : e ANGHI NONI, 1980). A extrapolação destes dados para condições de cam po, entretanto, pode representar resultados não satisfatórios devido às variações em termperatuxa, umidade e grau de homoge neização com o solo. Os trabalhos com plantas em vasos näo fo ram conduzidos por um período suficiente para reação completa das particulas mais grossas, superior a 2 anos (LOVE et alii, 1960 e TEDESCO e ANGHINONI, 1980).

Alēm disso; a informação de pesquisa disponível in dica que as maiores diferenças entre as frações granulomētri cas são observadas neste intervalo de partículas (diâmetro de $2,00$ a $0,25 \mathrm{~mm})$, porquanto as frações de menor diâmetro tendem a nivelar seus efeitos nos primeiros 12 meses de atuação no so 10. 
2.5. Eficiência dos Calcários na Correção da Acidez dos So los

A eficiência dos calcários depende do teor de carbo natos, do grau de moagem, da estrutura cristalina do material, do teor de umidade, da temperatura do solo, do tipo de vegeta ção, do manejo do solo, etc.

Como a correção da acidez dos solos é feita pelo ion carbonato, cuja reação inicial de hidrōlise no solo é:

$$
\mathrm{CaCO}_{3}+\mathrm{H}_{2} \mathrm{O} \rightarrow \mathrm{Ca}^{2+}+\mathrm{HCO}_{3}^{-}+\mathrm{OH}^{-}
$$

torna-se claro que a eficiência do calcário é proporcional ao teor de carbonato, "princípio ativo" ou o componente neutrali zante dos calcários.

A importância do conteúdo de neutralizantes nos cor retivos é öbvia. No entanto, os diferentes constituintes neu tralizantes têm diferentes capacidades de neutralização da aci dez. A fim de que o teor neutralizante reflita também a capaci dade de neutralizaçao, esse teor é expresso em "equivalente em carbonato de cálcio" ( $\left.\mathrm{CaCO}_{3}\right)$, ao qual se atribuiu o valor 1 ou $100 \%$ à sua capacidade de neutralização. A capacidade de neu tralização dos diferentes constituintes estã apresentada na Tabela 1 . 
TABELA 01 - Equivalente em carbonato de cálcio dos diferentes constituintes neutralizantes dos corretivos.

\begin{tabular}{|c|c|c|c|c|}
\hline \multirow[t]{2}{*}{ Constituintes } & \multicolumn{3}{|c|}{ Equivalentes } & \multirow{2}{*}{$\mathrm{E}_{\mathrm{CaCO}_{3}}^{\frac{\circ}{0}}$} \\
\hline & Fórmula & em $100 \mathrm{~g}$ & ${ }^{\mathrm{E}} \mathrm{CaCO}_{3}$ & \\
\hline Carbonato de cälcio & $\mathrm{CaCO}_{3}$ & 2,00 & 1,00 & 100 \\
\hline Carbonato de magnésio & $\mathrm{MgCO}_{3}$ & 2,37 & 1,19 & 119 \\
\hline Hidróxico de cálcio & $\mathrm{Ca}(\mathrm{OH})_{2}$ & 2,70 & 1,35 & 135 \\
\hline Hidróxido de magnésio & $\mathrm{Mg}(\mathrm{OH})_{2}$ & 3,43 & 1,72 & 172 \\
\hline Oxido de cälcio & $\mathrm{CaO}$ & 3,57 & 1,79 & 179 \\
\hline бxido de magnésio & $\mathrm{MgO}$ & 4,96 & 2,48 & 248 \\
\hline Silicato de cấlcio & $\mathrm{CaSiO}_{3}$ & 1,72 & 0,86 & 86 \\
\hline Silicato de magnésio & $\mathrm{MgSiO}_{3}$ & 1,99 & 1,00 & 100 \\
\hline
\end{tabular}

Assim, dispondo-se do teor dos constituintes neutra lizantes de um corretivo, o seu $\mathrm{E}_{\mathrm{CaCO}_{3}}$ é facilmente calculado:

$\begin{array}{lc}\text { Teor de óxidos no corretivo } & \circ \mathrm{E}_{\mathrm{CaCO}_{3}} \\ 25 \% \text { de } \mathrm{CaO} \text { e } 15 \% \text { de } \mathrm{MgO} & 25 \times 1,79+15 \times 2,48=82,0 \\ 35 \% \text { de } \mathrm{CaO} \text { e } 3 \% \text { de } \mathrm{MgO} & 35 \times 1,79+3 \times 2,48=70,1 \\ 60 \% \text { de } \mathrm{CaO} \text { e } 12 \% \text { de } \mathrm{MgO} & 60 \times 1,79+12 \times 2,48=137,2 \\ 80 \% \text { de } \mathrm{CaO} \text { e } 1 \% \text { de } \mathrm{MgO} & 80 \times 1,79+1 \times 2,48=145,7\end{array}$


Referências feitas na literatura, tanto estrangeira (BARBER, 1967) como nacional (MALAVOLTA, 1967), consideram que corretivos com um teor equivalente em $\mathrm{CaCO}_{3}$ abaixo de $80 \%$ são de baixa qualidade.

A legislaşão dos Estados Unidos da América estabele ce diferentes mínimos em ${ }^{\circ} \mathrm{E}_{\mathrm{CaCO}_{3}}$, para a comercialização dos diversos corretivos (AAPFCO,1976): cal virgem - 140; cal extin ta - 110; calcário, escórias e sambaquis - 80).

A legislação brasileira (BRASII, 1982) não estabe lece um mínimo de $\mathrm{E}_{\mathrm{CaCO}_{3}}$ para os corretivos. Porém, exige um mínimo de 38\% na soma dos óxidos de cälcio e de magnêsio. Se, hipoteticamente, o óxido for exclusivamente cao, o ${ }^{-\mathrm{CaCO}_{3}}$ é 68. Essa condição não è comum e qualquer substituição de cao por Mgo eleva substancialmente esse valor.

Apesar da óbvia importância do teor de neutralizan tes do corretivo, as recomendações de calagem ainda não eștão suficientemente refinadas para levar em conta esse fator. As considerações que têm sido feitas são empíricas e essa carên cia compromete, pelo menos em parte, o estudo econômico que aparentemente parece ser bastante viável, a respeito das pos síveis vantagens do calcário calcinado, cuando se computa princi palmente o custo do transporte.

A composição química de qualquer material calcário expressa seu poder neutralizante num estado potencial e por conseguinte, sua capacidade em corrigir a acidez do solo. Não indica, porém, sua eficiência. Conforme tem sido demonstrado 
conclusivamente, a rapidez de reação de um calcário no solo ou em qualquer meio ácido diluido, depende, em grande parte, do estado de divisão do material.

A ação dos calcários no solo ocorre através do con tato entre ambos: quanto maior a superfície do contato, mais rápida será sua ação. Sabe-se que quanto menor o tamanho das partículas de um material, maior é a sua superfícje de exposi ção, razão porque o tamanho das partículas dos corretivos cons titui uma caracteristica fundamental da qualidade, particular mente nos calcários.

Mais recentemente, tem-se interessado, no Brasil, em avaliar a eficiência relativa das diferentes frações granu lométricas dos calcários. No sul do país têm sido utilizados valores estabelecidos nos Estados Unidos da América do Norte. RAIJ (1977) estimou valores baseando-se em trabalho de VERLEN GIA e GARGÃNTINI (1972), no qual utilizou 2 calcários, um cal cítico e um dolomítico, e um tipo de solo. Estes dois conjun tos de valores referidos estão condensados na Tabela 02 . 
TABELA 02 - Estimativas da eficiência de diferentes granulomētricas de calcários, no Brasil.

Fraçāo Granulométrica

Eficiência Relativa*

A

(은)

maior do que 10

$10-20$

$10-50$

$20-60$

menor do que 50

menor do que 60
0

20

$-$
60

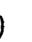

100

B

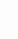

0

40

$-\quad 100$
0

*A: Valores adotados no suj. do Brasil; a fração granulométri ca é dada em "mesh".

B: Valores encontrados por RAIJ(1977); a fraçäo granulonëtri ca é dada em nọ de peneira - USBS.

Atravēs dos valores da eficiência relativa de cada fração poảe-se avaliar a eficiência relativa (ER) de um calcá rio em função de sua composição granulométrica através da ex pressão:

을alcärio

$$
F_{1} \cdot \frac{E r_{1}}{100}+F_{2} \cdot \frac{E r_{2}}{100}+\ldots+F_{n} \cdot \frac{E r_{n}}{100}
$$


onde: $F_{1} \cdot 2 \cdot \ldots n=$ percentual das diversas frações granulomẹ tricas.

Err'2'...n = eficiênca relativa percentual das respecti vas. frações granulométricas.

RAIJ (1977), utilizando as composições granulométrí cas de 32 amostras de calcários, cuja média foi $20,3 \%, 20,6 \%$, $8,3 \%$ e 49,1ํํㄹ para as frações 10-20, 20-50, 50-60 e menor do que 60, respectivamente, calculou as eficiências relativas em função da granulometria, com base nas taxas que estabeleceu e nas utilizadas no sul do país: no segundo caso os valores fo ram sempre inferiores, cuja média foi $70,6 \%$ contra $73,8 \%$.

Considerando-se as condições elevada acidez dos so los brasileiros e o clima quente e relativamente úmido, permi te-se supor, pelomenos que a reatividade dos calcários deva ser maior do que nas condições norte-americanas. Assim conclue-se que as taxas utilizadas no sul e as de RAIJ (1977) devem estar subestimando a reatividade dos calcários nas condições do Brasil. Também, uma das fraçōes granulométricas considera das no critério sulino (fração 20-60) e no critério de RAIJ (1977) (fração 10-50) é bastante ampla para se atribuir um úni co valor para a sua eficiência. Mas não resta dúvida que novas estimativas semelhantes devem ser feitas, com calcários e so los diversificados, aperfeiçoando-se então a representatividade des 
sas taxas.

Quanto ao tamanho das partículas mineralógicas (ex pressas em "mesh" ou em milímetros e classificados pela tamisa ção atravës de grupos convencionais de peneiras), muitos são os trabalhos existentes e relacionados com a solubilidade.

GARGANTINI (19.74), em trabalho com diferentes granu lometrias de calcários calcíticos e dolomíticos, avaliadas em função das produções de milho e trigo, nostrou que não foi ob servada diferença, em efeito, para as diferentes granulome trias dos corretivos estudados.

Os trabalhos de pesquisa realizados com 0 intuito de medir a eficiência das partículas de calcário com diversas granulometrias na correção da acidez do solo são unânimes em afirmar que o aumento da superfície específica do material, pe lo fracionamento dos grânulos, favorece a ação corretiva no solo (LOVE et alii, 1960; MIELNICZUK et alii, 1971; WüNSCHE e BOHNEN, 1976).

Os experimentos de SHAW e ROBINSON (1960), onde se estudou a eficiência de calcário de diferentes graus de finu ra, utilizando-se lisímetros, chegou-se à conclusão que calcá rio passado em peneira de 60 mesh dissolveu-se em dois anos e o passado em peneira de 8 mesh em 3-4 anos. Neste mesmo traba Tho concluiu-se que o calcário dolomítico é tão eficiente quan to o calcítico, quando o calcário dolomítico é duas vezes mais fino que o calcário calcítico.

Trabalhos de BEAR e TOTH (1952) determinaram que 
partículas de calcário que atravessam a peneira de 150 mesh e sâo retidas em peneira de 200 mesh são completamente dissolvi das em solos ácidos. A eficiência baixa para $87,5 \%$ para o cal cário que fica entre 65-100 mesh, para 33,2\% no calcário reti do entre peneira de 20-28 mesh e para 17,8\% para o material re tido na peneira de 10-14 mesh.

Pesquisas de MEYER e VOLK (1952) mostraram que as mudanças de pH do solo ocasionadas pela aplicação de correti vos da acidez dependem mais do tamanho das partículas e do tem po de contato que do tipo de calcário (calcítico ou dolomíti co). Verificaram também que a elevação do pH foi de 0,13 após um mês de aplicação de um calcário dolomítico passado em penei ra de 4-8 mesh, ao passo que quando se usou peneira de 100 mesh, neste mesmo período, a elevação foi de 1,6. Observaram que $\mathrm{o}$ pH do solo que recebeu calcário de peneira mais grossa que 20 mesh decresceu após um mês, onde apuraram que o acréscimo inicial se deveu ao pó que envolve as partículas mais grosseiras. Geralmente, os valores de pH mais elevados ocorrem 6 meses após a aplicação do calcário. Para peneiras 50-60 mesh o valor pH mais elevado ocorreu aos 12 meses, ao passo que, para as partículas que não atravessam a peneira 50 mesh o va lor de $\mathrm{pH}$ mais elevado ocorreu aos 18 meses. Ficou provado que calcários com granulometria abaixo de 20 mesh são pouco efí cientes, pois não houve alteração no pH inicial após 18 meses de contato. Quantidades iguais de calcários calcíticos e dolo 
míticos de igual finura elevam o pH após 6 a 9 meses de sua aplicação; essa mesma tendência verifica-se para as frações que não passam pela perieira 50 mesh apōs 18 meses de aplicação. Entretanto, acima de 9 meses, materiais dolomíticos de peneira 50 ou mais fina causaram maior elevação do pH do que o calcá rio calcítico de igual finura. Materiais passados em peneiras entre 20-30 mesh, cujas quantidades aplicadas foram de 20 t/ ha, reagiram após 18 meses e verificou-se que toda partícula que não passa na peneira 40 mesh pareceu possuir igual va lor neutralizante.

Em experimento onde se visou observar o efeito ime diato de calcários calcíticos e dolomíticos de diferentes graus de finura no trevo vermelho, bem como residual na alfa fa, BEACHER et alii (1952) observaram que o trevo vermelho não se desenvolveu quando o calcário não foi aplicado ou então quando o calcário calcítico ou dolomítico de peneira 20-40 mesh foi usado. O calcärio calcítico de peneira 60-80 mesf foi eficiente, mas o dolomitico, de tamanho correspondente, foi ineficiente. Cal cários dolomíticos e calcíticos mais finos que peneira 100 mesh foram tão eficientes quanto a cal hidratada na produção e redü ção dos teores de hidrogênio, alumínio e manganês trocáveis. 0 calcário dolomítico foi tão bom quantoao calcítico para penei ra mais fina que 100 mesh. O crescimento da alfafa mostrou que o efeito residual dos calcários passados em peneira de 20-40 mesh ainda era ineficiente. Tanto o calcário calcítico como o dolomítico de peneira 60-80 mesh mostraram influência residual 
na alfafa. Foi verificado que a acidez trocável foi de 3,1 e. $\mathrm{mg} / 100 \mathrm{~g}$ de solo e também maior valor de $\mathrm{pH}$, menor teor de alu mínio e maior teor de cálcio quando se usou o calcário calcíti co passado em peneiras de 100-200 mesh.

Em relação à granulometria de materiais calcários, LEPSCH et alii (1968) observaram que 14 amostras apresentaram uma porcentagem acumulativa que passa pela peneira de no 50 me nor que 50\%, sendo este um valor abaixo do limite mínimo esta belecido pela legislação, sendo que a porcentagem que pássa pe la peneira de no 50 nunca foi inferior a 40\%. Também verifica ram que em média 97\% a 100\% de materiais procedentes de seis regiões passam pela peneira de no 10 quando a legislação exige que passe $100 \%$ do material.

A eficiência das frações granulométricas pode ser medida por seus efeitos no solo ( $\mathrm{H}^{2}, \mathrm{Al}^{3+}, \mathrm{Ca}^{2+}, \mathrm{Mg}^{2+}$, etc). Estudos realizados por BRAGA et alii (1971), onde se procurou apreciar o efeito de calcário sobre os níveis de pH, cálcio, magnésio, fósforo e potássio do solo, mostraram que em uma das localida des estudadas, embora o pH tenha sido inferior, os teores de cálcio foram maiores. A análise de variância mostrou signifi cância onde a causa da variação foi a profundidade, e que as maiores quantidades de calcário aplicadas não alteram o teor de cálcio no solo. Notourse também que as doses não afetam a quantidade de cálcio na profundidade de $0,20 \mathrm{~m}$, não havendo, portanto, movimento descendente pronunciado do cálcio, isto provavelmente devido à não solubilização dos compostos de cál 
cio existentes no solo ou adicionado na forma de carbonato de cálcio, ou devido ao tempo de contato que foi relativamente curto. O teor de cálcio adicionado correlacionou-se significa tivamente com os valores de $\mathrm{pH}$ apenas na primeira amostragem a $10 \mathrm{~cm}$ de profundidade.

BARBER (1967) diz que é desejável utilizar um calcá rio que reaja completamente com o solo dentro de dois a três anos. Considerando que a rapidez de reação está relacionada com a finura e que a maior moagem aumenta o custo do produto. Ain da diz que o calcário agrícola precisa conter material fino pa ra promover uma rápida correção da acidez do solo e, ao mesmo tempo, incluir algum material menos fino, de modo que os bene fícios da calagem se estendam por um período de tempo mais lon go.

Diz ELPHICK (1955) que as formas de avaliação da efetividade do calcário pelos diversos autores têm sido prin cipalmente: a) pela razão de dissolução dos carbonatos no solo ou outros meios ácidos; b) pelos efeitos sobre as propriedades dos solos, como pH, saturação de bases, etc; e c) pelos efe tos sobre a produção de culturas.

Quanto à forma química dos carbonatos, tem sido con siderado que os calcários calcíticos são mais reativos do que os dolomíticos, principalmente na literatura norte - americana (BARBER, 1967). No Brasil, GALLO et alii (1956) não verifica ram diferença entre ambos na cultura de soja. VERLENGIA e GAR GANTINI (1972) encontraram que o calcário dolomítico foi mais 
efetivo do que o calcítico na elevação do pH do solo. GARGANTI NI (1974) obteve os mesmos efeitos entre ambos no aumento de produção da massa seca de milho e de trigo.

BEACHER et alii (1952) observaram que partículas de igual tamanho de dolomita e de calcários calcíticos foram igualmente eficientes para a produção de alfafa. Por outro la do, em se tratando de material calcítico, partículas dos mesmos corretivos, de igual tamanho, porém mais finas ou iguais a 80 mesh, foram muito mais eficientes na produção do trevo ver melho.

A eficiência de um calcário na correção de acidez do solo e sua disponibilidade de $\mathrm{Ca}$ e Mg às plantas dependem de uma série de fatores conjugados. Se, entre os fatores que dizem respeito ao material calcário, o poder neutralizante, o tipo de material, o grau de finura e a dose e maneira de apli cação do calcário são de elevada importância agrícola e econô mica, entre os fatores extrínsecos, as condições de clima e de solo, as perdas por lavagem, bem como por remoção pelas plan tas, e as exigências das culturas, dificultam sobremaneira o cálculo da quantidade de corretivo a ser incorporado, como tam bém o julgamento do valor efetivo dos materiais calcários.

2.6. Avaliação da Qualidade dos Calcários por Métodos Quími $\cos$

Dentre as diversas características relacionadas com 
a qualidade dos corretivos de acidez do solo, duas se mostram as mais importantes e são as que têm sido consideradas na ava Iiação da qualidade desses produtos: granulometria e teor de neutralizantes.

Em relação ã granulometria, no Brasil, a exigência oficial é de que os corretivos devem passar 100\% em peneira no 10 (ABNT) e, no mínimo, 50\% em peneira no 50 (ABNT).

Quanto ao teor de neutralizantes, a avaliação é fei ta através da determinação do poder de neutralização (PN), que consiste em digerir brandamente a amostra de corretivo com uma quantidade conhecida e excessiva de ácido em solução relativa mente dilusda $(0,5 N)$. O excesso de ácido que não reage é poste riormente determinado e a quantidade de ácido neutralizada pe lo corretivo é o seu PN e é expresso em ${ }^{\circ} \mathrm{E}_{\mathrm{CaCO}_{3}}$. $\mathrm{E}$ como os neu tralizantes devem estar na forma de cálcio e de magnésio, es tes constituintes também são determinados e expressos em forma de óxidos. A primeira vista, pode-se inferir que,quanto maior o teor de neutralizantes, melhor a qualidade do corretiva. Contudo, o aumen to da capacidade de neutralização dos corretivos è acompanhada nas carac terísticas quimicas e físicas dos solos que apresentam diversas desvanta gens no caso dos óxidos e hidróxidos, razāo porque o calcário calcínado po deria se constituir numa alternativa interessante (ALCARDE, 1982). A legislação brasileira exige que os corretivos apresen tem 67\% de poder de neutralização (com tolerância para menos de até $20 \%$ da garantial e 38\% na soma dos óxidos de cálcio e de magnésio (com tolerância para menos de até $10 \%$ da garantia 
da soma, sem exceder a $20 \%$ para o óxido de magnësio).

Através da avaliação desses dois parâmetros, isto é, granulometria e teor de neutralizantes, separadamente, fica difícil definir quantitativamente a qualidade de um corretivo; e isso impede o seu uso racional em função da qualidade, face às necessidades dadas pelas recomendações de calagem.

Tal dificuldade levou ä idealização de um índice que traduzisse a eficiência de um corretivo contemplando es sas duas características de qualidade: o Poder Relativo de Neu tralização Total (PRNT), surgido nos Estados Unidos e utiliza do no Estado de Ohio daquele país (MISDALE e NELSON, 1975), o qual é obtido pela expressão:

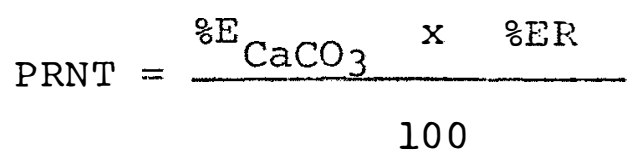

sendo: $\quad{ }^{\circ} \mathrm{E}_{\mathrm{CaCO}_{3}}=1,79 \times \div \mathrm{CaO}+2,48 \times \div \mathrm{MgO}$

:ER = eficiência relativa porcentual em função da granulometria.

Observação: o valor de ${ }^{\circ} \mathrm{E}_{\mathrm{CaCO}_{3}}$ poderia, ou melhor, deveria ser o determinado no poder de neutralização. Ocorreque a metodologia oficial brasileira (BRASIL, 1982) es tabeleceu, para essa determinação, o uso de amos tra tal qual é comercializada e nessas condições 
- valor PN encontrado é normalmente menor do que o obtido pelo cálculo indicado. Isso porque, na de terminação do PN a digestão da amostra é branda, não sendo efetiva sobre as partículas mais grossei ras e na determinação do cálcio e do magnésio a digestão é enérgica, promoverdo a solubílização to tal. O ideal seria usar o valor obtido do PN, cuja determinação fosse feita na amostra moída e passa da em peneira no 100 (ABNT) (AOAC, 1980).

$A$ adoção desse índice oficialmente no Brasil vem sendo sugerida há alguns anos. Apesar da sua indiscutível uti lidade, a sua não oficialização até agora é devida à indefini ção existente na avaliação da eficiência granulométrica. Porém, tem sido utilizado extra-oficialmente, empregando, no cálculo da eficiência granulométrica, as taxas adotadas no sul do país e as adotadas no Estado de São Paulo, as quais foram apresen tadas no ítem 2.5. 
3. MATERIAIS E METODOS

Os ensaios foram conduzidos em casa-de-vegetação na Escola Superior de Agricultura "Iuiz de Queiroz" - USP Piracicaba, SP, no período de agosto de 1980 a novembro de 1981. Estes ensaios constituíram-se de incubações em três tí pos de solo com quatro tipos de calcários visando ao ". estudo da eficiência de quatro frações granulométricas dos calcários.

\subsection{Materiais}

$$
3.1 .1 . \text { Solos }
$$

Foram empregados trēs solos äcidos, de regiões de vegetaçäo de cerrado,provenientes de Brasilia (DF) e Assis (SP). Os solos foram retirados de uma camada entre $0-30 \mathrm{~cm}$, secos ao e peneirados a $2 \mathrm{~mm}$.

$$
\text { A classificação dos solos utilizados encontra - se }
$$
na Tabela 03. 
TABELA 3 - Classificação dos solos utilizados

PROVENIENNCIA

CLASSIFICAÇÃO

Brasília (DF) Latossolo Vermelho Amarelo - Distrófico Argiloso-LVd
Brasília (DF) Latossolo Vermelho Escuro - Diströfico Argiloso-LEd
Assis (SP)
Latossolo Verme lho Escuro - Fase arenosa - LEa

As caracteristicas físicas e químicas dos três so Ios LVa, LEd, LEa, se encontram na Tabela 4.

\subsubsection{Corretivos}

Forarn utilizados dois tipos de calcārios, isto é, sedimentar e metamórfico, separados em 4 frações granulométri cas, a saber: as frações retidas entre as peneiras nos, 5-10, 10-30, 30-50 e 50-60 (Associação Brasileira đe Normas Técnicas - ABNT).

As anälises químicas dos corretivos estão apresen tadas na Tabela 05. 


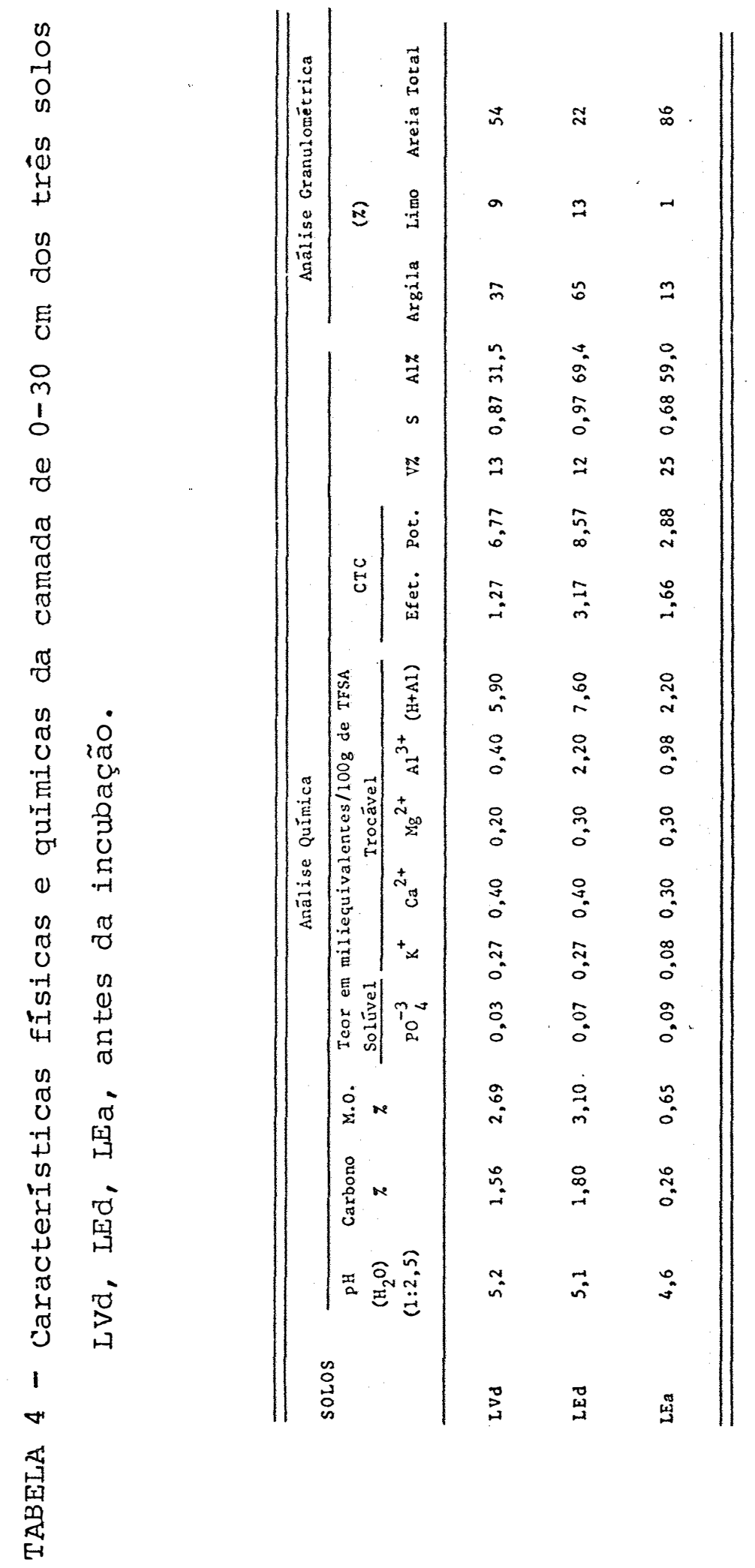


TABELA 05 - Teores de öxidos de cälcio e de magnésio nas di ferentes frações granulométricas dos calcários es tudados. (Média de 5 repetições)

응

Calcärios Granulometria

$\mathrm{CaO} \quad \mathrm{MgO}$

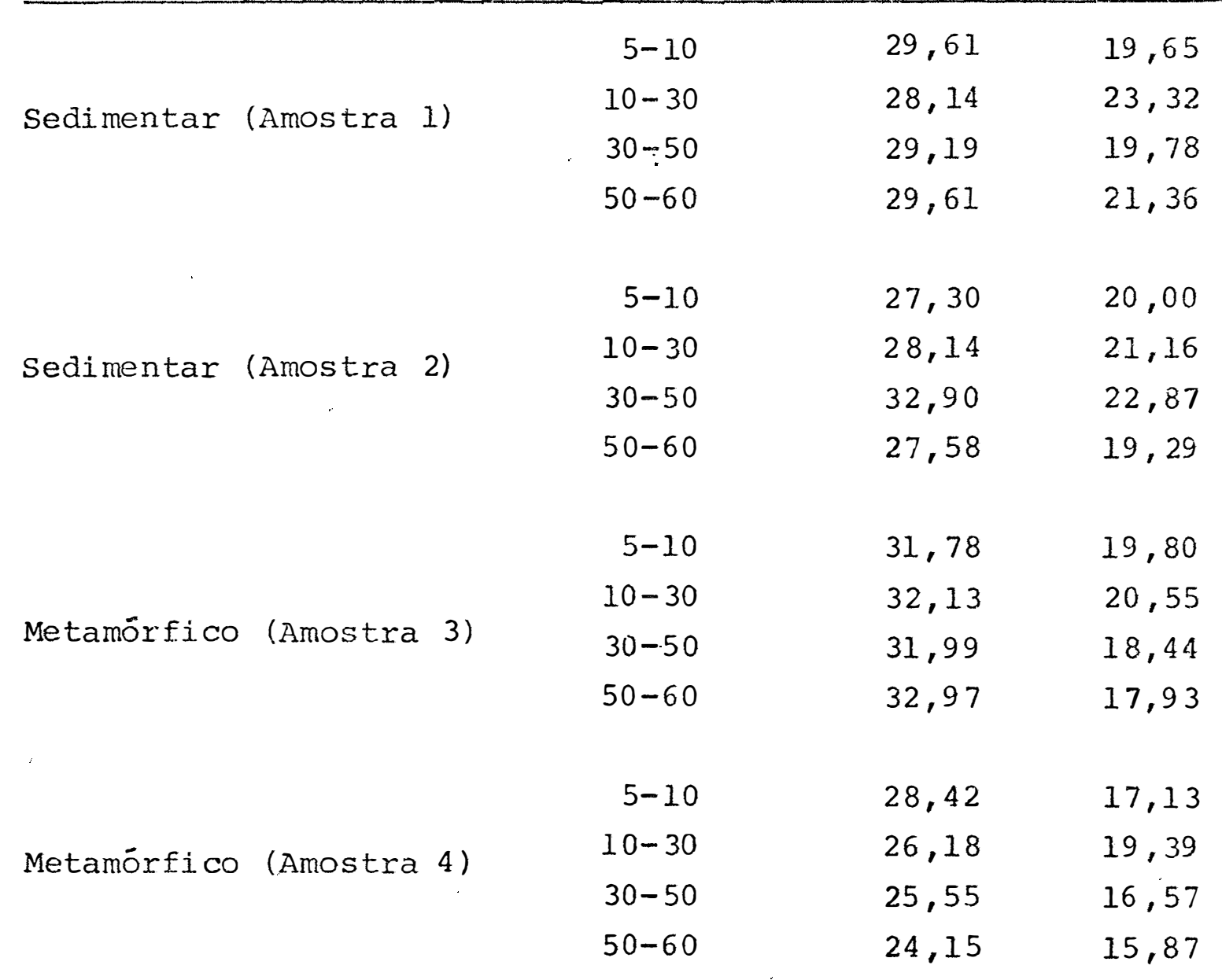


3.2. Métodos

As doses de calcário foram calculadas com base na

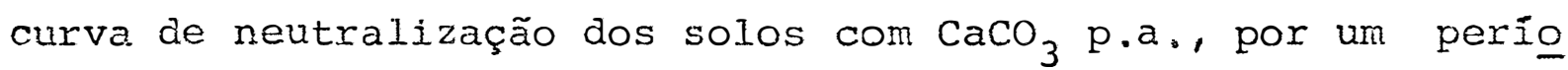
do de 40 dias. Essas curvas foram obtidas adicionando-se ao so lo, quantidades crescentes de $\mathrm{CaCO}_{3}$ p.a., correspondentes a 2 , 4, 6 e 8 t/ha, no caso dos solos LVd e LEa e 4, 8, 12 e 16 t/ ha, no caso do solo LEd, em função do seu alto poder tampão(1). As respectivas curvas são mostradas nas Figuras 1, 2 e 3.

As unidades experimentais foram constituidas de $500 \mathrm{~g}$ de solo, colocados em copos de polietileno. Cada Exáção granulométrica dos calcários foi misturada com o solo utilizan do-se uma quantidade equivalente à de óxidos necessários para elevar o pH a 6,5; o ensaio foi realizado em casa de vegetação, com controle de umidade $(30 \%)$. Após períodos de 8 , $16,32,48,64,80,96,128$ e 160 dias, foram coletadas amos tras de solo, homogeneizando-se o total de solo de cada vaso, seguido de retirada da amostra, a qual foi seca ao ar. Determi nou-se imediatamente nas mesmas o pH e os teores de cálcio, mag nésio e aluminio trocáveis.

o pH foi determinado em água na proporção de $1: 2,5$ (solo-água) após 30 minutos de repouso com auxílio de um poten ciômetro com escala expandida. Os teores de cálcio e magnésio

(1) Informação BOLETIM No 2 - EMBRAPA - PLAiNALTINA (DF). 

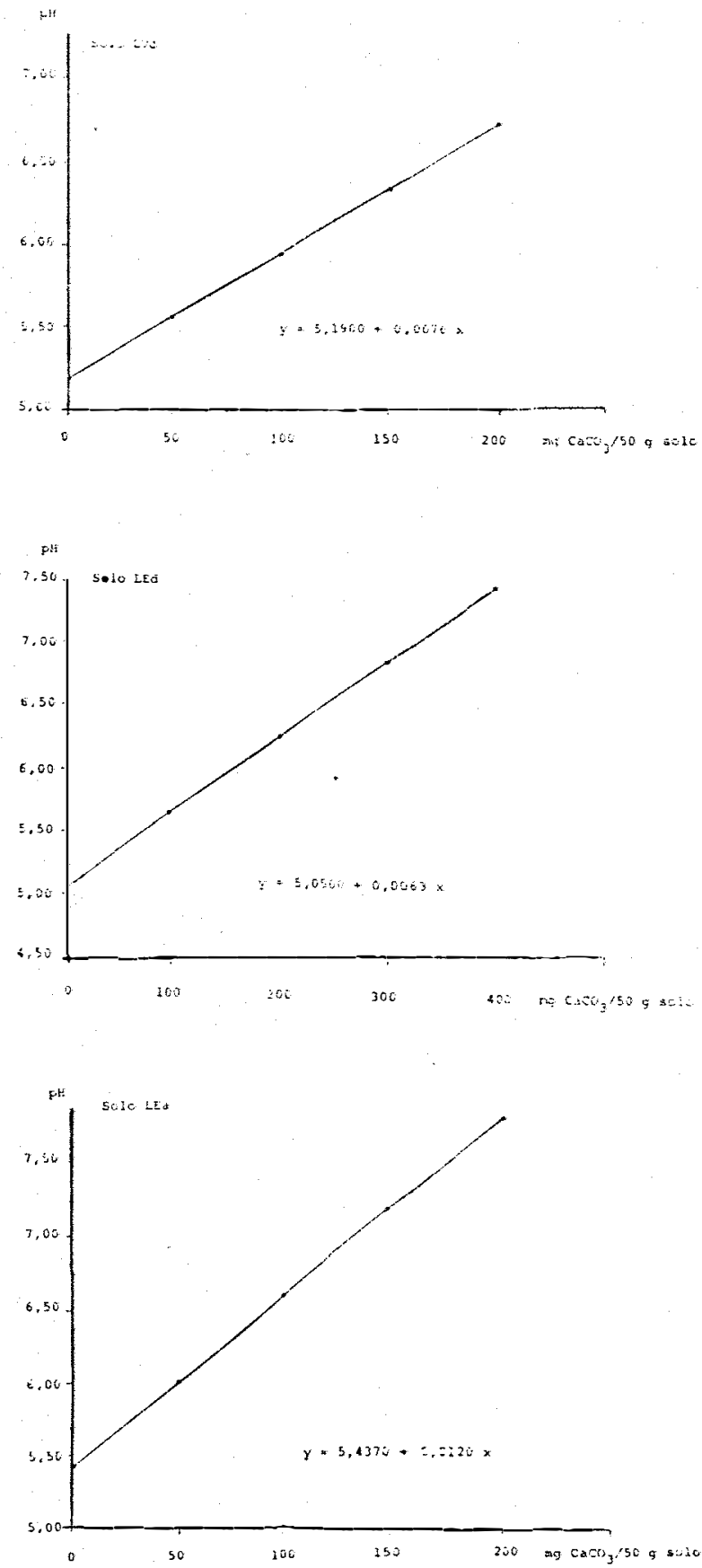

FIGURAS 1 a 3 - Relação dada pela equação de regressão linear, entre $\mathrm{pH}$ e quantidades de $\mathrm{CaCO}_{3} \mathrm{p} \cdot \mathrm{a} \cdot$ (mg/50 g solo), determinada por incubação. 
foram determinados por quelatometria e o de aluminio por alca limetria, no produto da extração com KCl-lN (VETTORI, 1969).

\subsection{Delineamento Experimental}

O delineamento utilizado foi o Inteiramente casuali zado, num esquema fatorial 3 x 4 x 4 (3 tipos de solo, 4 calcá rios e 4 frações granulométricas), com 4 repetições. Conside rando-se que as amostragens foram repetidas no tempo, fez-se para cada tratamento a regressão polinomial, até 39 grau. 
4. RESULTADOS E DISCUSSÃO

4.1. Valor $\mathrm{pH}$

$4 \cdot 1 \cdot 1$. Solo LVd

Na Tabela 06 são apresentados os dados médios dos valores pH do solo LVd em função de 09 tempos de incubação para os quatro tipos de calcáxios com as suas diferentes fra ções granulométricas.

Na Tabela 07 são apresentados os valores de F pa ra as equações de primeiro, segundo ou terceiro grau, levando-se em conta somente os que deram significativos. Nas Figuras 04 a 07 são apresentadas gráfica e matematicamente as equações obtidas.

Observa-se pelas Figuras 04 e 05 que os calcá rios sedimentares mais grosseiros j-10 e 10-30 (ABNT), não a 1 teraram significativamente o valor pH do solo, fato este tam bëm observado por (BOHNEN \& WUNCHE, 1972; VERIENGIA e GARCANTTIN, 


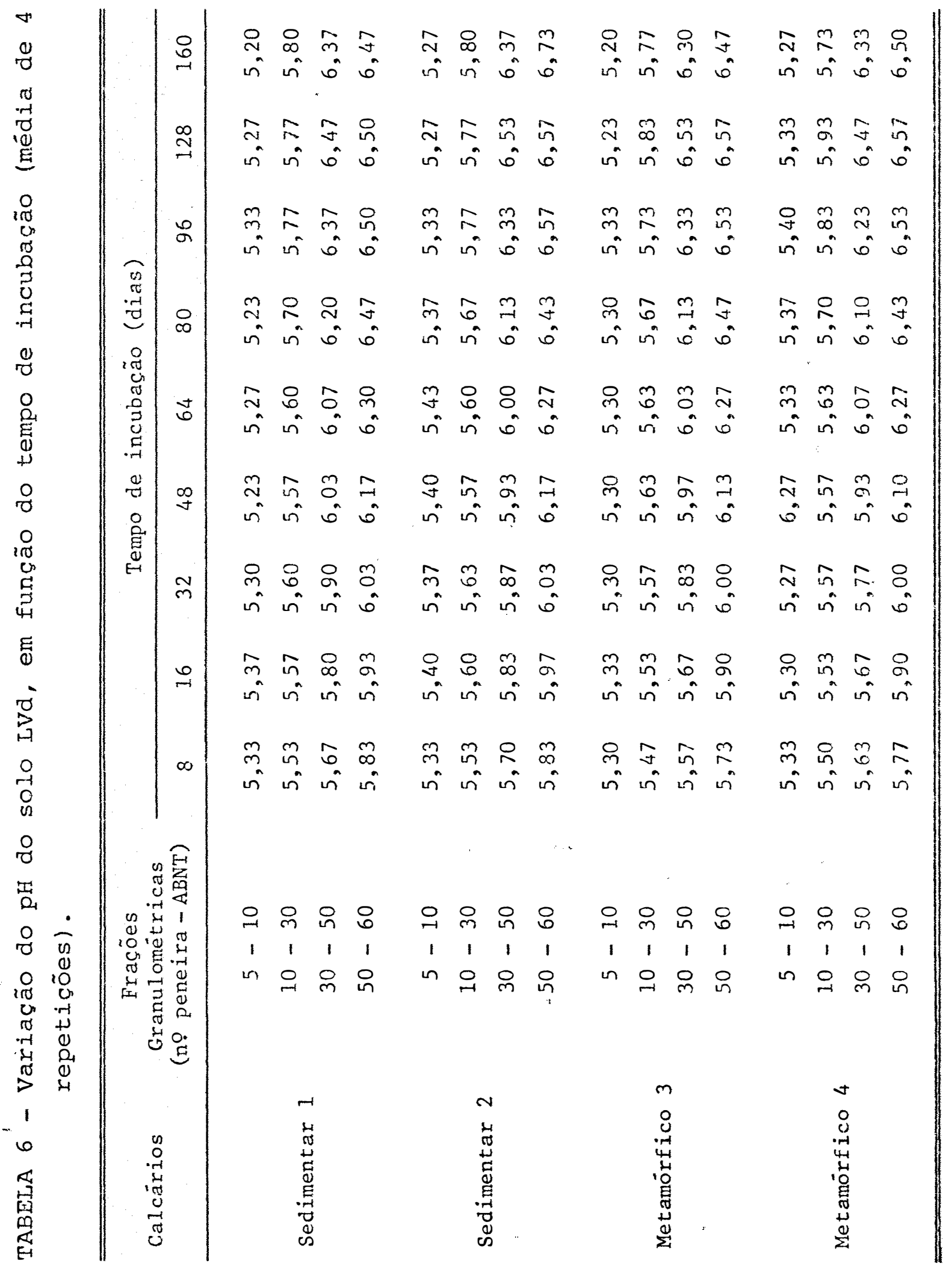




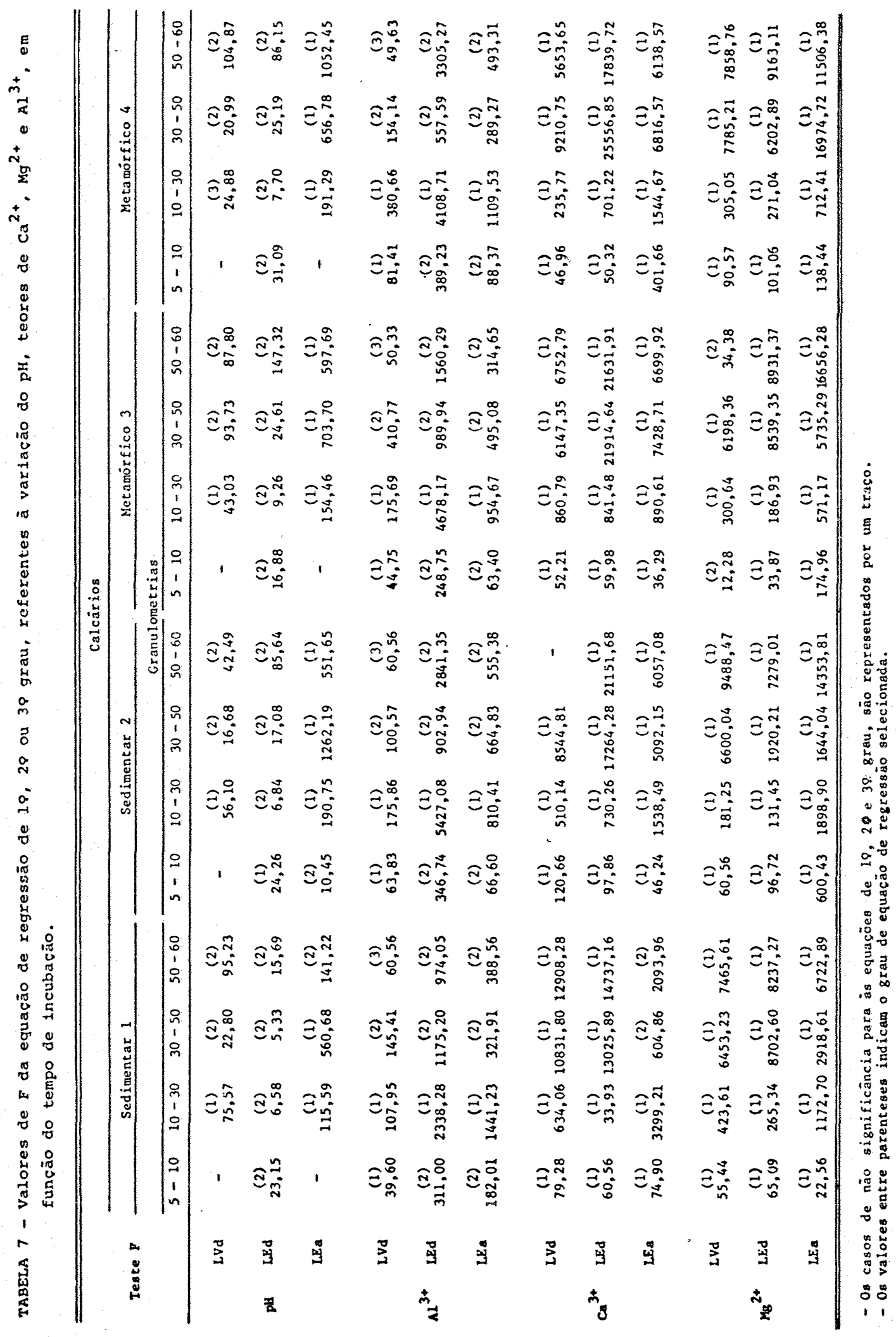


1972), a fração 5-10 do calcário metamórfico (Figuras 06 e 07) não alterou o valor pH do solo, porém a fração 10-30 alte rou significativamente. Deve-se citar que para as curvas ob tidas que não foram significativas são apresentados os valo res de Y médio. Pelas curvas representativas, bem como: pela equação, nota-se que a diferença que existe entre sedimentar e metamórfico deve-se provavelmente à diferença química das amostras, apesar de que a mesma não é elevada (Tabela 05).

Quanto à real efetividade dos calcários e de suas frações os dados mais significativos foram obtidos pará os quatro calcários dentro das frações 30-50 e 50-60 (ABNT), sen do que sempre o mais fino reagiu melhor, elevando mais rapi damente o valor $\mathrm{pH}$ do solo, como aqueles obtidos por MIELNICZUK et alii, 1971; SOUZA e NEPTUNE, 1979; TEDESCO e ANGHINONI, 1980. Nas Figuras 04 a 07 vê-se a representação gráfica bem como as respectivas equações.

Dentro da fração 30-50, após o cálculo do Ponto de Máxima Eficiência Tēcnica (M.E.T.), procurou-se determinar o ponto máximo de valor pH atingido em funçăo do tempo, deter minando-se o valor 6,39 para o calcário metamórfico-3.

Igual raciocínio se fez para a fração 50-60 (ABNI), para os calcários, obtendo-se os valores pH 6,65 aos 127 dias para o calcário sédimentar-l. 
LVA - Sedlmentar 1

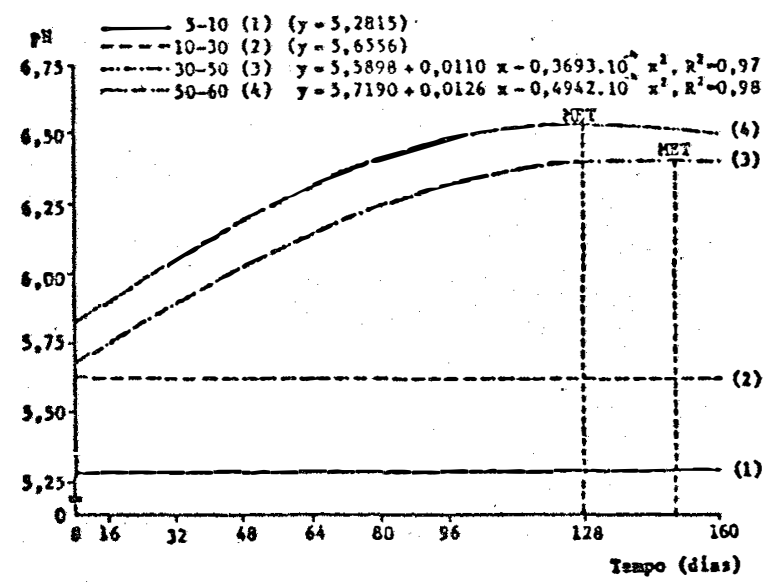

IVd - Sedimentar 3

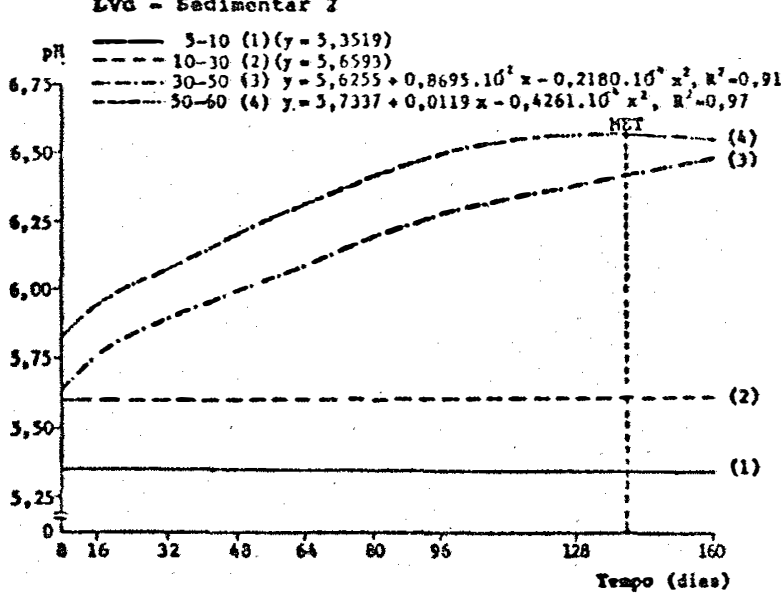

LVd - Netamörf1co 3

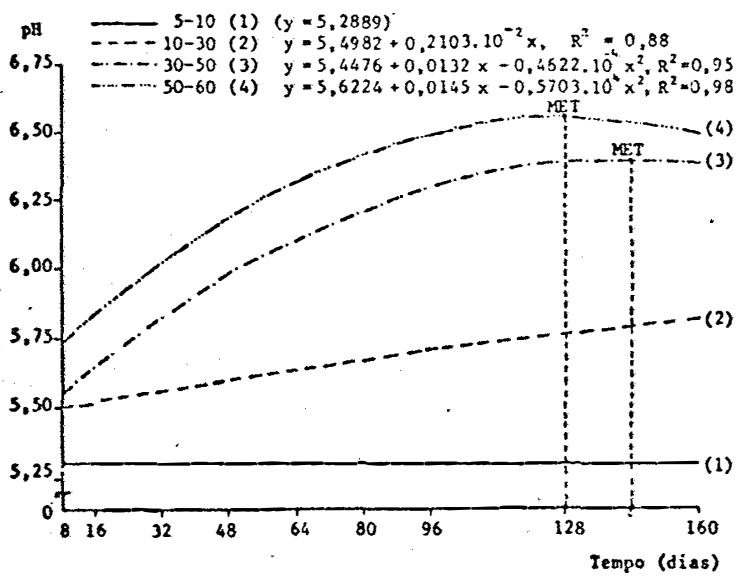

LVa - Metanór 1 ico

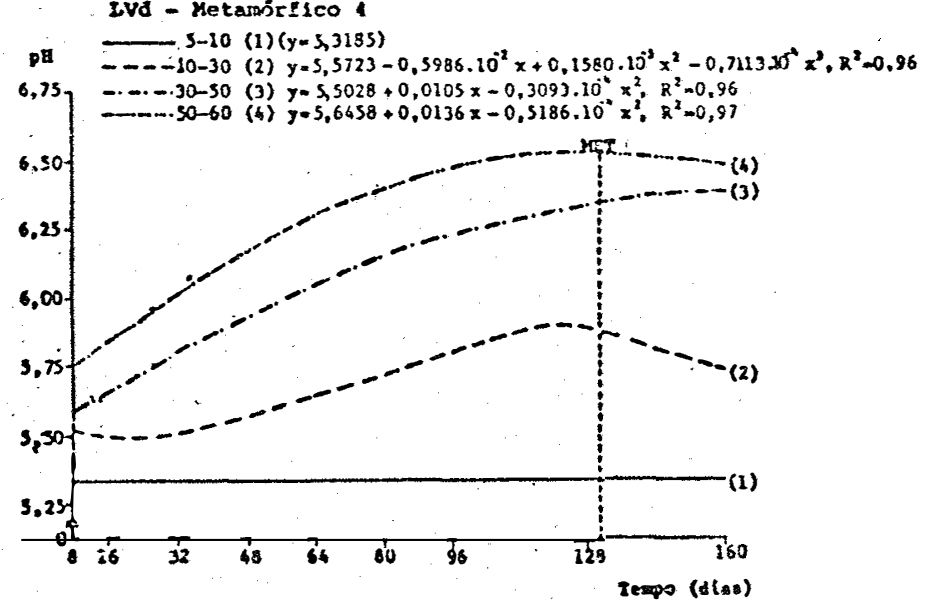

FIGURAS 4 a 7 - Representação gráfica da equação de regressão polinomial do pH em função do tempo de incuba ção, no solo LVd com os quatro tipos de calcá rios. 
$\mathrm{Na}$ Tabela 08, encontram-se os dados referentes a va lores pH em função do tempo de incubação bem como dos diferen tes calcários com as diferentes frações.

Na Tabela 07, são apresentados os valores de F, pa ra as equações do primeiro, segundo ou terceiro grau.

Nas Figuras de 08 a ll, são apresentadas gráfica e matematicamente as equações obtidas.

Para este solo, observa-se nas Figuras 08 a ll uma variação no välor $\mathrm{pH}$ diferente daquela obtida para o solo LVd, pois, somente para um àos calcários sedimentares-2, e um đos metamórficos-3 é que a fração 5-10 não reagiu, indepen dentemente do tempo de incubação. Para a fração 10-30,0 que não se notou para os calcários sedimentares l e 2 no solo LVd foi observado no solo LEd para todos os calcários. A possí vel explicação desse fato pode ser dada pelo potencial de ácidos oriundos da decomposição de um maior teor de matéria orgānica, o qual solubilizaria frações mais grosseiras de cal cário, associada ao maior teor de argila, o qual aumentaria a superfície especifica de contato, porém, a elevação do vâ lor do $\mathrm{pH}$ não foi marcante, pois, tanto a matéria orgânica co mo o teor de argila, dão a esse solo maior poder tampão, in duzindo com isso variabilidades menores que aquelas observadas nos solos LVd e IEEa.

O comportamento de reação das frações 30-50 e 50-60 para os quatro tipos de calcários foram de ordem quadrática, 


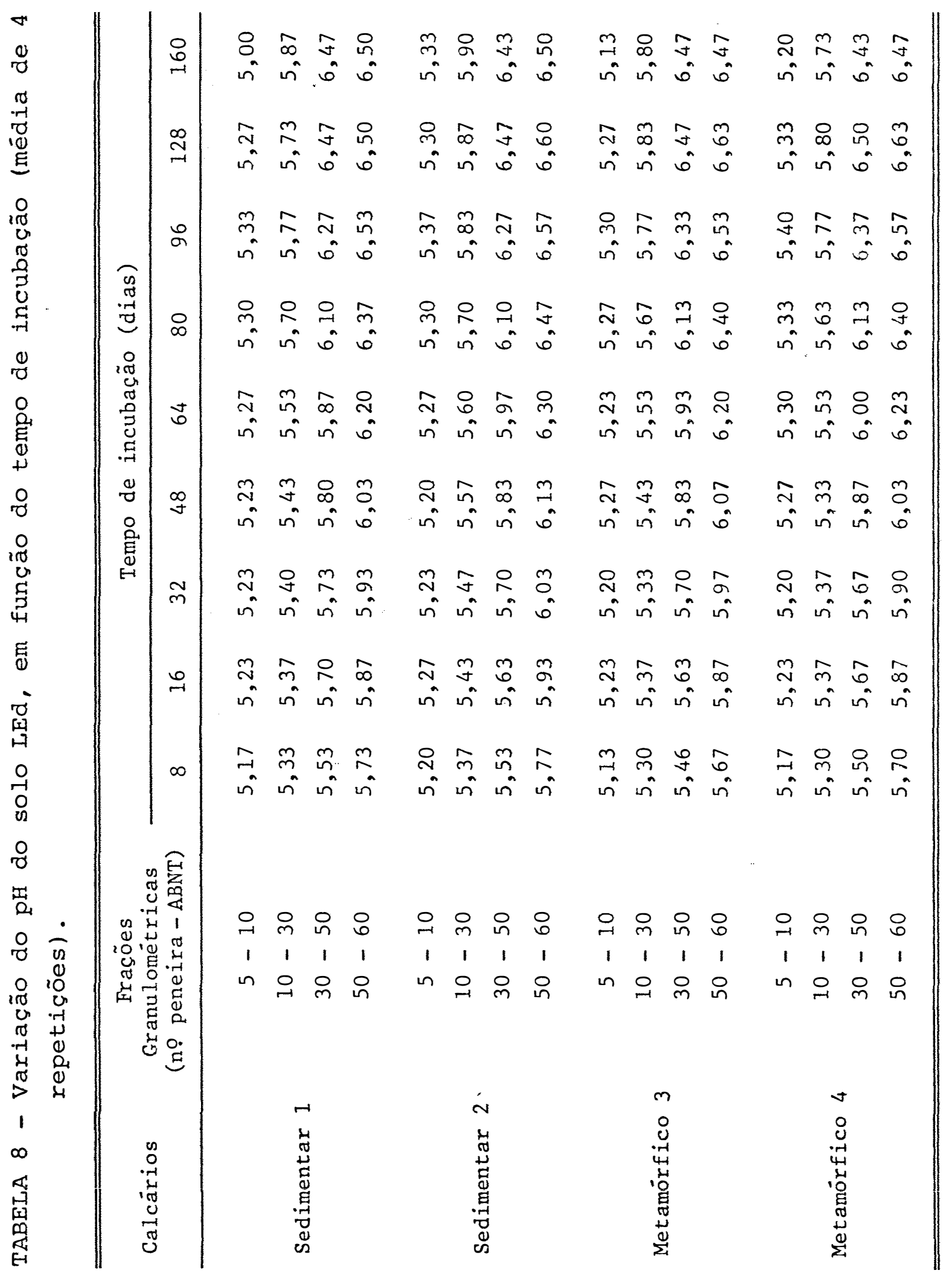



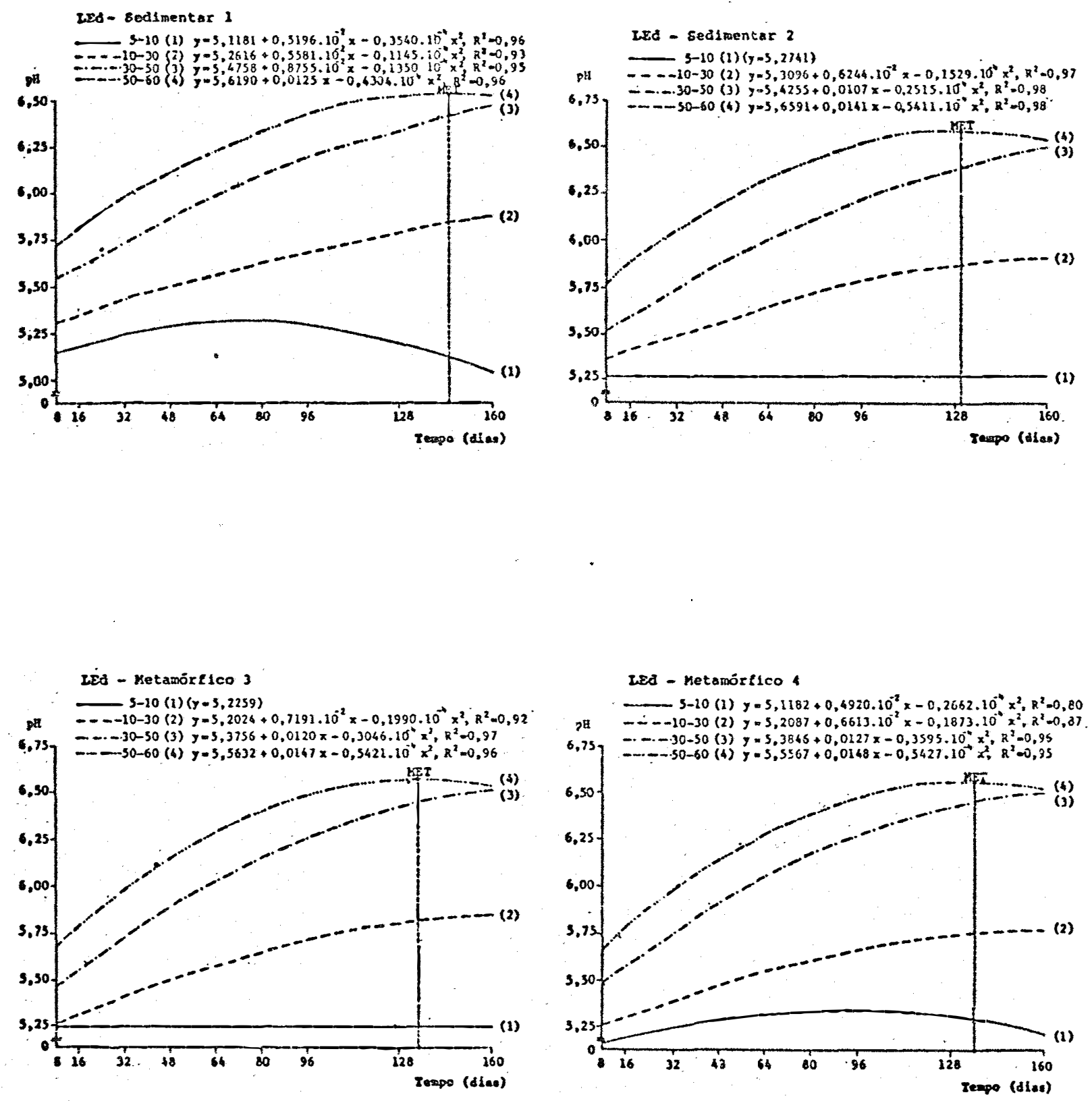

FIGURAS 8 a 11 - Representação gráfica da equação de regressão polinomial do pH em função do tempo de incuba ção, no solo LẸ com os quatro tipos de calcă rios. 
bastante semelhantes inclusive com aqueles apresentados para - solo LVd (Fiquras 04 a 07), porém, deve-se notar que no tem po de 160 dias, dentro do solo LEd a eficiência da fração 3050 tende a igualar àquela da fração 50-60.

Calculando-se o Ponto de Máxima Eficiência Técnica (M.E.T.) em função das equações obtidas e levando-se em con ta somente aqueles valores obtidos dentro do intervalo de tem po estudādo (atē 160 dias), obteve-se para a fração 50-60, o maior valor $\mathrm{pH}$ en função de todos os calcārios e tempos, o qual foi de 6,59 aos 130 dias para o calcário sedimentar-2.

\subsubsection{Solo LEa}

Na Tabela 09, são encontrados os valores pH em função do tempo de incubação bem como dos quatro calcários com suas quatro diferentes frações granulométricas.

Na Tabela, 07, são apresentados os valores de F, pa ra as equações de primeiro, segundo ou terceiro grau.

Nas Figuras de 12 a 15 são apresentadas gráfica e matematicamente as equações obtidas. Para a fração mais gros seira 5-10, independentemente do tipo de calcário não se detec tou reação, mantendo-se constante o valor pH em função do tem po de incubação; todas as outras frações, com exceção da 50-60 para o calcário sedimentar-1, tiveram uma reação linear em função do tempo, mas sempre a granulometria mais fina reagiu 


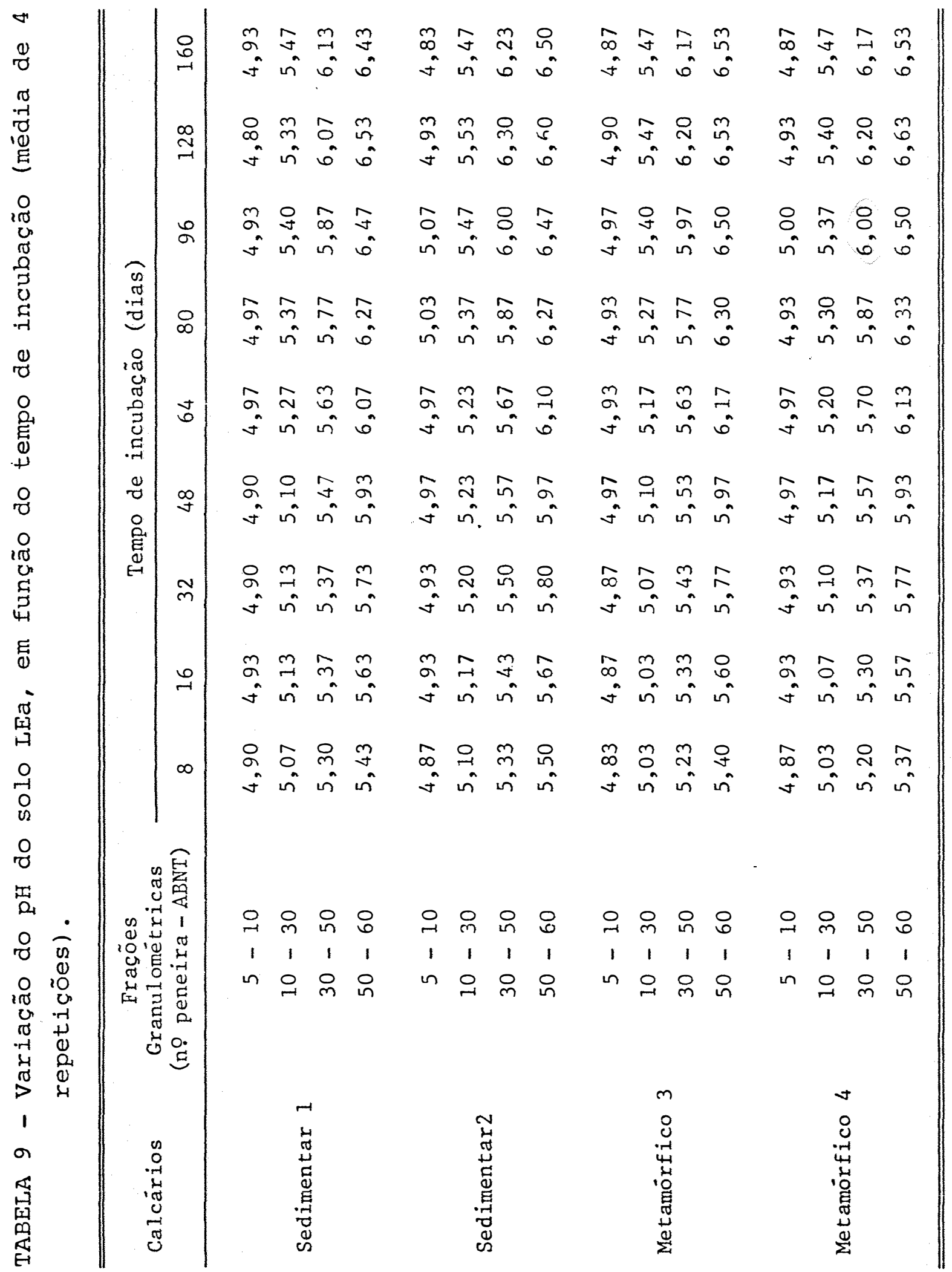



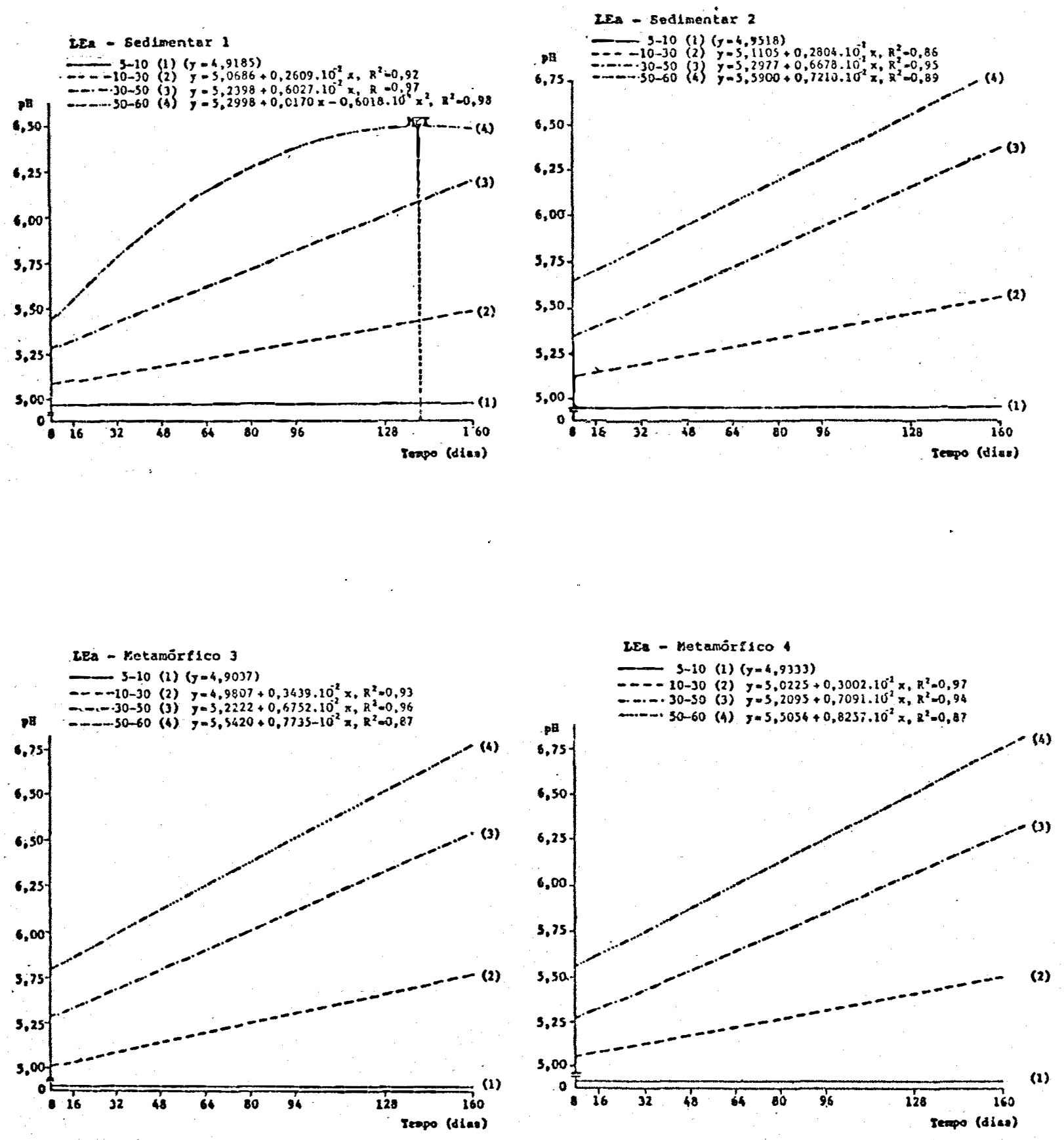

FIGURAS 12 a 15 - Representação grāfica da equação de régressão polinomial do pH em função do tempo de incubą ção, no solo LEa com os quatro tipos de calcā rio. 
mais que as grosseiras, elevando-se, portanto, o valor $\mathrm{pH}, \mathrm{con}$ firmando nesse ponto os trabalhos de VERLENGIA e GARGANTINI (1972). Essa maior reatividade dos calcários nesse tipo de so 1o, em função dos anteriormente citados, deve-se provavelmen te ao teor de matéria orgânica que é de $0,65 \%$, o teor de argi la que é 13\% e o de areia total de 86\%, materiais esses que em conjunto condicionam uma baixa CTC do solo. Nesses tipos de solo em relação aos outros dois, para fins agrícolas devese usar uma dose menor de calcários.

Como somente para o calcário sedimentar-l cbteve-se uma equação de regressão quadrática, calculou-se para tanto o Ponto de Máxima Eficiência Técnica (M.E.T.), o qual proporcio nou um valor pH de 6,56 no tempo de 141 dias. Deve-se frizar que para fins de fertilidade de solo,não é detodo interessante a obtenção de equações de regressão lineares, pois, isto in dica que o solo não atingiu o seu ponto de equilíbrio, e que aí se torna difícil fazer suposição a respeito de qual calcāa rio seria o melhor e qual seria o tempo de melhor reaçào, pois, observando-se as Figuras 13 a 15 vê-se que os valores pH obtí dos aos 160 dias, aproximam-se de 7,0.

4.2. Teor de $\mathrm{Al}^{3+}$ 4.2.1. Solo LVd

Na Tabela 10, são apresentados os valores de $\mathrm{Al}^{3+}$ 


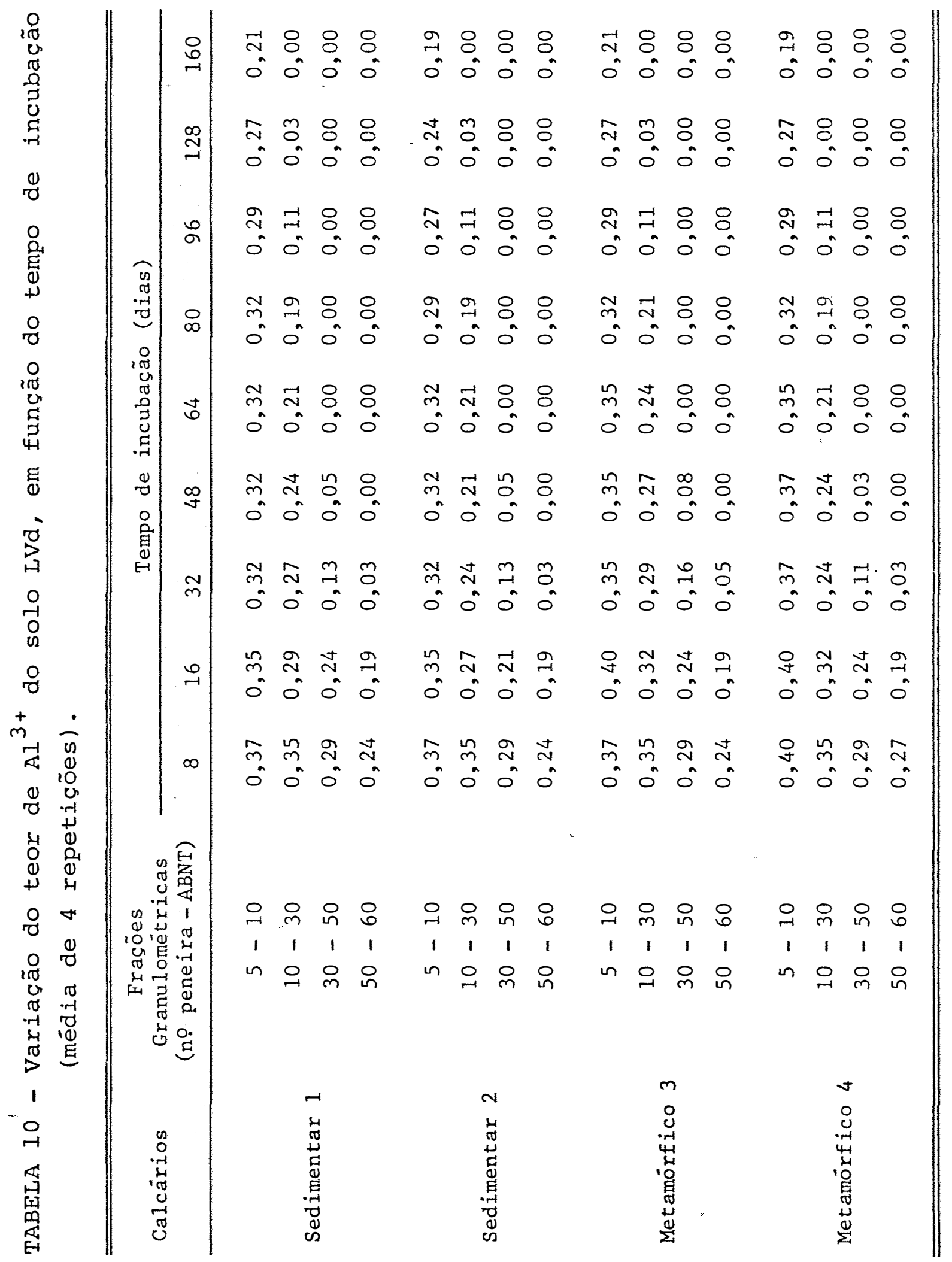


em função do tempo de incubação. dos quatro calcārios com seus quatro graus de finura.

Na Tabela 07 , são apresentados os valores de F, pa ra as equações de primeiro, segundo e terceiro grau.

Nas Figuras de 16 a 19 são apresentadas gräfica e matematicamente, as equações obtidas.

Independentemente do tipo de calcārio, as frações 5-10 e 10-30 não neutralizaram totalmente o $\mathrm{Al}^{{ }^{+}}$, mesmo no tempo de 160 dias a não ser para o caso do calcário sedimen tar-1, cujo teor de $\mathrm{Al}^{3^{+}}$para a fração 10-30 foi eliminado no tempo de 148 dias, Figura 16, fato também observado por BOHNEN e WÜNCHE (1972), valor este que. rão se deve levar em conta em função do tempo decorrido, pois a nível agrícola perde a sua aplicabilidade.

Sempre a fração 50-60 reagiu em um menor tempo que a de 30-50, para os quatro tipos de calcārios, mas esses cal cārios eliminaram $\circ \mathrm{Al}^{3^{+}}$do solo, em períodos que tiveram a seguinte variabilidade:para a fração 30-50 necessitou-se de 72 a 84 dias e,para a fração 50-60, este tempo ficou reduzido para a faixa de 51 a 57 dias, dando, portanto, um período mẹor em cerca de 30 dias, o que representa, para a agropecuária um pra zo bastante grande, tendo-se em vista a necessidade que se tem de plantios não muito tardios; isto é, no início das águas, pois, a aplicação do calcārio se faz em julho e agos to. 

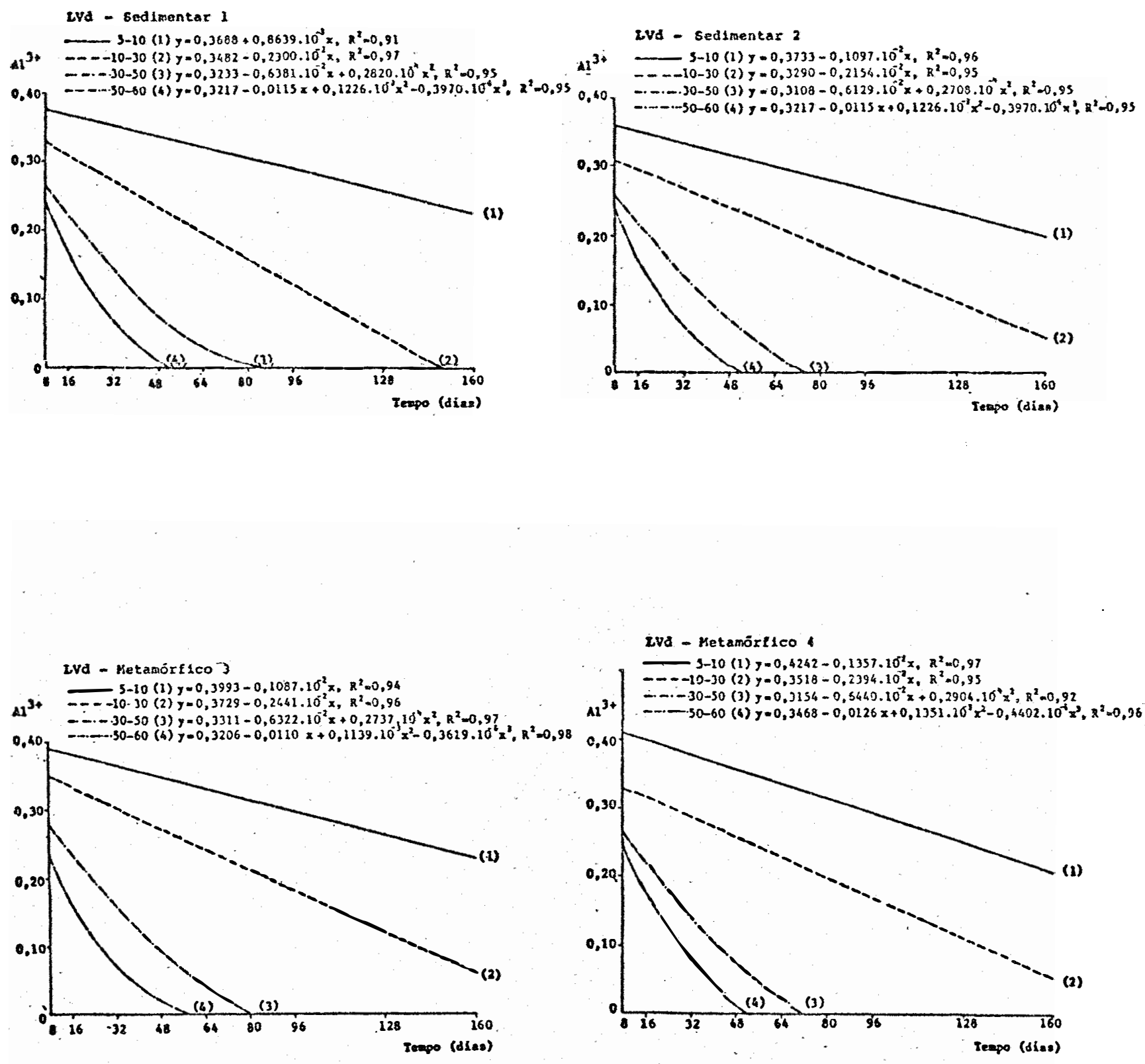

FIGURAS 16 a 19 - Representação grăfica da equação de regressão polinomial do $\mathrm{Al}^{3+}$ em função do tempo de incu bação, no solo LVa com os quatro tipos de cal cāríos. 
Deve-se citar que o teor original de $\mathrm{Al}^{3+}$ desse so lo era de 0,40 e.mg/100 g TFSA e que para as frações mais fí nas 30-50 e 50-60, já, aos 8 dias, quando se iniciaram as de terminações, esses teores já tinham decrescidos numa faixa en tre 0,24 e 0,29 e.mg. Se levarmos em conta a saturação do $\mathrm{Al}^{3+}$, obteve-se que para o calcário mais fino, 50-60, a saturação diminuiu de $31,4 \%$ para $19 \%$. Em vista disso, sugere-se que as determinações $\mathrm{Al}^{3+}$, quando se usa calcário mais fino, seja feita em intervalo de tempo menores que aqueles do presente ensaio.

\subsubsection{Solo LEd}

Na Tabela 1l, são encontrados os valores de $\mathrm{Al}^{3+} \mathrm{em}$ função dos tempos de incubação e dos calcārios e frações utị lizadas.

Na Tabela 07, são apresentados os valores de F, pa ra as equações de primeiro, segundo e terceiro grau.

Nas Figuras de 20 a 23 , são apresentadas gráfica e matematicamente, as equações obtidas. Independentemente do tipo de calcário e de suas respectivas frações, as curvas tí veram um comportamento semelhante. A granulometria mais gros seira 5-10 teve efeito quadrático, pois se nota que até cer ca de 48 dias a mesma não netralizou $\mathrm{A} \mathrm{Al}^{3+}$, porém, logo apōs esse período, o fez de maneira quadrática, em função do 


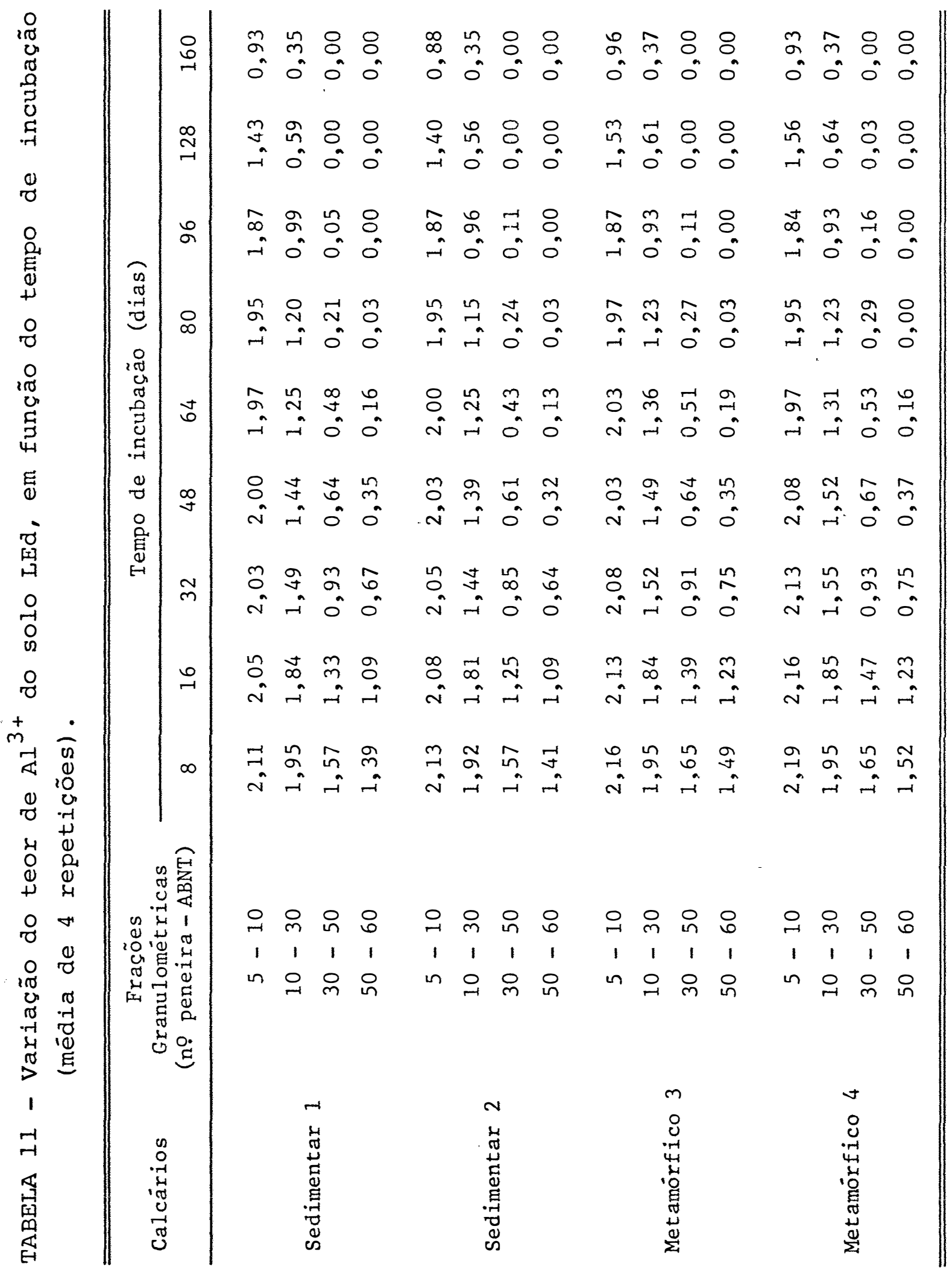



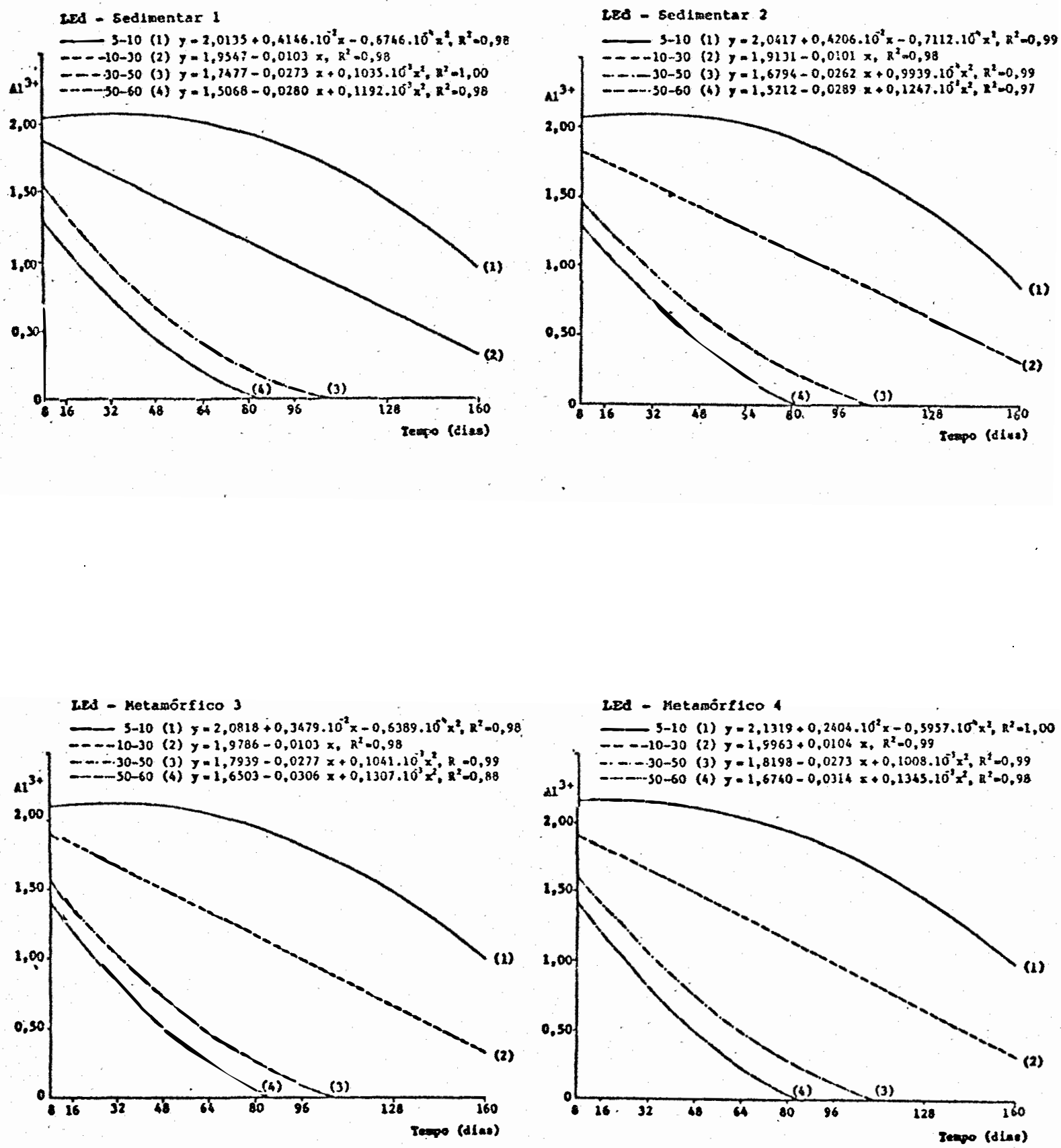

FIGURAS 20 a 23 - Representação gráfica dạ equação de regressão polinomial do $\mathrm{Al}^{3+}$ em função do tempo de incu bação, no solo LEd com os quatro tipos de cal cārio. 
tempo.

- Para a fração 10-30, a neutralização do $A \ell^{3^{+}}$, não ocorreu de maneira total, porēm, foi linear até os 160 dias. Por outro lado, as frações $30-50$ e 50-60 eliminaram $\circ \mathrm{Al}^{3^{+}}$do solo, porēm sempre a mais fina foi a mais eficiente para a fração 50-60 a eliminação. do $A \ell^{3^{*}}$ se deu entre 81 a 86 dias $e_{\text {: }}$ para a fração 30-50, entre 106 e 109 dias, isto é, cerca de 25 dias a mais. Deve-se notar que este período é bastante se melhante àquele obtido para o solo LVd.

\subsubsection{Solo LEa}

$\mathrm{Na} T$ abela 12, encontram-se os dados do $\mathrm{Al}^{3^{+}}$em $\mathrm{E}$ un ção dos tempos de incubạção e dos quatros tipos de calcários, com seus quatros graus de finura.

Na Tabela 07 , säo apresentados os valores de $\mathrm{F}$, pa ra as equações de primeiro, segundo e terceiro grau.

Nas Figuras 24 a 27 são apresentadas,gráfica e ma tematicamente as equações obtidas.

o comportamento das curvas de reação dos calcários, independentemente das granulometrias, são bastante semelhantes com as citadas para o solo LEd, alterando-se somente os va lores quantitativos, confirmando em parte as afirmações de WUNCHE e BOHNEN (1972). A fração 5-10, apesar de efeito qua drático, praticamente não reagiu até os 48 dias, o que era de 


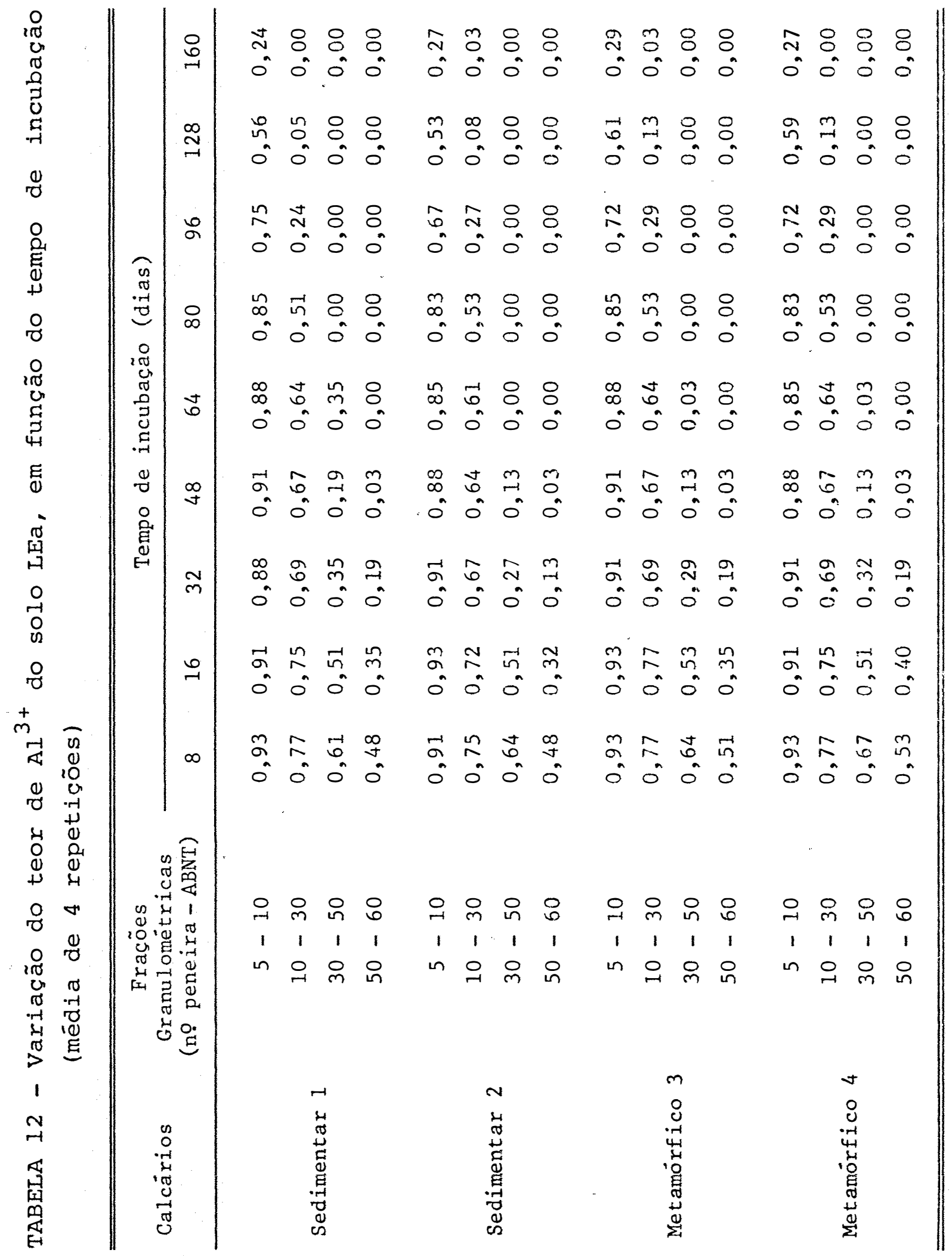



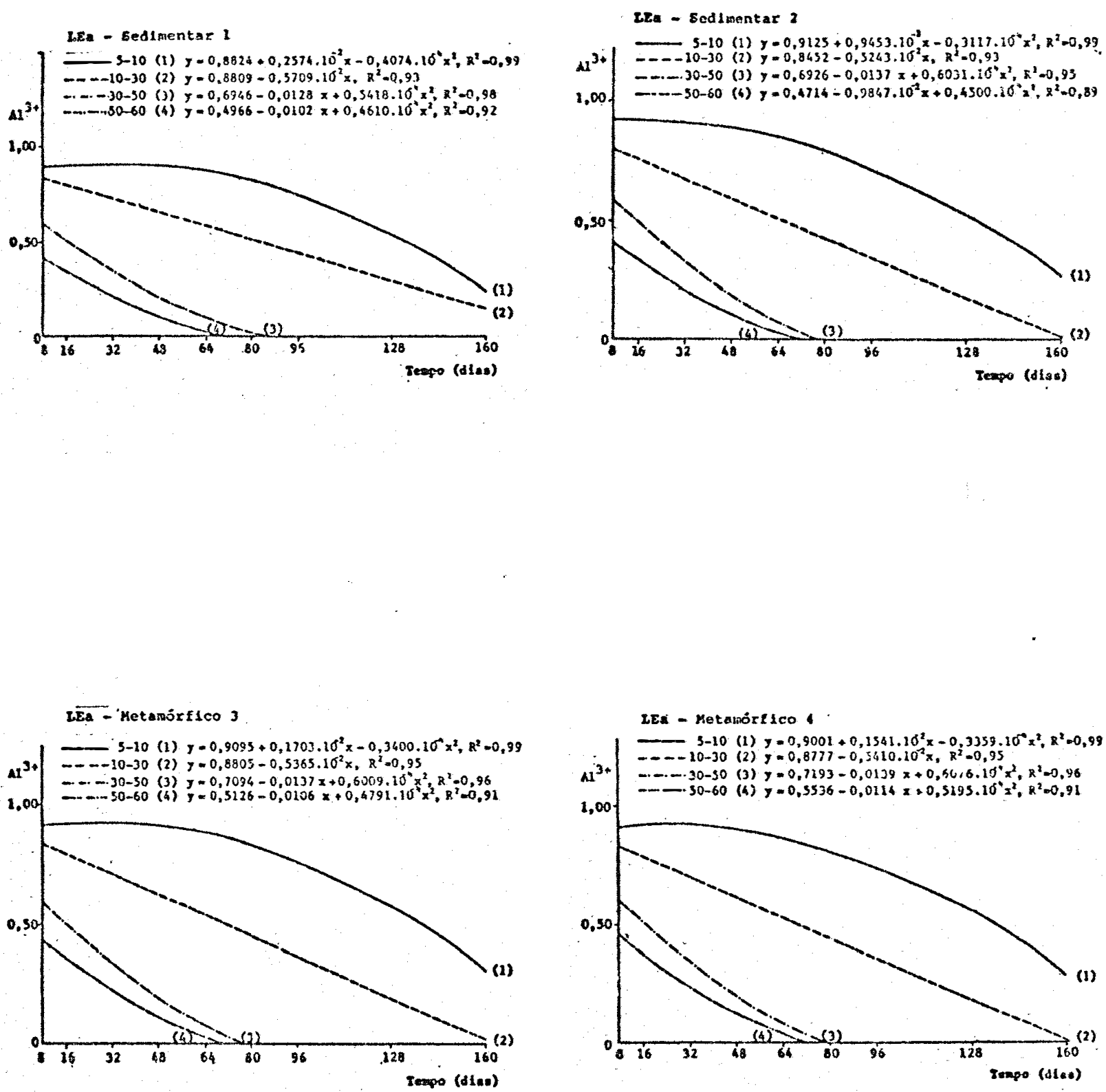

FIGURAS 24 a 27 - Representação gräfica da equação de regressão polinomial do $\mathrm{Al}^{3+}$ em função do tempo de incú bação, no solo LEa com os quatro tipos de cal cários. 
se esperar, tendo-se em vista que o solo é pobre em matēria orgânica, e portanto, potencialmente pobre em àcidos que solu bilizariam essas partículas mais grosseiras, pois, a reação ocorre na superfície e ê por isto, lenta.

A fração 10-30 reagiu lineamente em função do tempo na diminuição do $\mathrm{Al}^{3^{+}}$, chegando para o calcārio sedimentar-2 e para os dois metamórficos, a eliminar o $\mathrm{Al}^{3^{+}}$no período de 160 dias de incubação, fato este não detectado para os solos LVd e LEd. Este comportamento pode ser explicado, como já o foi anteriormente, pelo baixo poder tampão desse soio, quer em fun ção do teor de matéria orgânica, quer em função do teor de ar gila. Para as granulometrias mais finas,30-50 e 50-60, já. aos 8 dias ( 1 á determinação) o teor de $\mathrm{Al}^{3^{+}}$decresceu de 0,98 e.mg para cerca de 0,50 e.mg para 50-60 e 0,64 e.mg para 30-50. Em função do tempo, observa-se nas Figuras 24 a 27 que $\circ \mathrm{Al}^{3^{+}}$ foi eliminado do solo em períodos de tempo bem mais curtos que nos outros solos. Para a fração 30-50 entre 76 a 84 dias e para a fração 50-60 entre 69 a 72 dias.

Deve-se citar que, em função da menor capacidade de troca catiônica desse solo, a diferença entre as eficiências dessas duas frações $30-50$ e 50-60 foi estreitada, pois, en quanto no LVd a variação era de 20 a 26 dias e no LEd de 20 a 33 dias, para o solo LEa essa faixa se situou entre 5 a 15 dias, mostrando que não se necessita de granulometrias muito finas para se eliminar $\circ \mathrm{Al}^{{ }^{+}}$do solo, quando o poder tampão 
desse è baixo.

Não. se deve esquecer que um calcārio comercial na da mais è do que uma somatöria de frações granulomētricas,e em função dessas poder-se-ia ter um material de PRNT específico para cada tipo de solo, pois, tudo indica que a eficiēncia do calcārio è mais marcante quando se leva em conta as proprie dades físicas e químicas do solo, que a própria eficiência re lativa do calcārio.

4.3. Teor de $\mathrm{Ca}^{2+}$

4.3.1. Solo IVd

Na Tabela 13, são encontrados os teores de $\mathrm{Ca}^{2+}$ em função do tempo de incubação bem como dos calcārios e seus graus de finura.

Na Tabela 07 , são apresentados os valores $F$, para as equações de primeiro, segundo e terceiro grau.

Nas Figuras de 28 a 31 , encontram-se as representạ ções grārica e matemātica das equações obtidas.

Pela observação das Figuras 28 a 31, nota-se, inde pendentemente do tipo de calcārio, uma semelhança bastante es treita entre as frações e a reação dessas em função do tempo, sendo todas representadas por equação linear. Praticamente, a fração mais grosseira (5-10)não alterou o teor de $\mathrm{Ca}^{2+}$ ao longo do tempo, porém a de 10-30 o fềz, de maneira não 


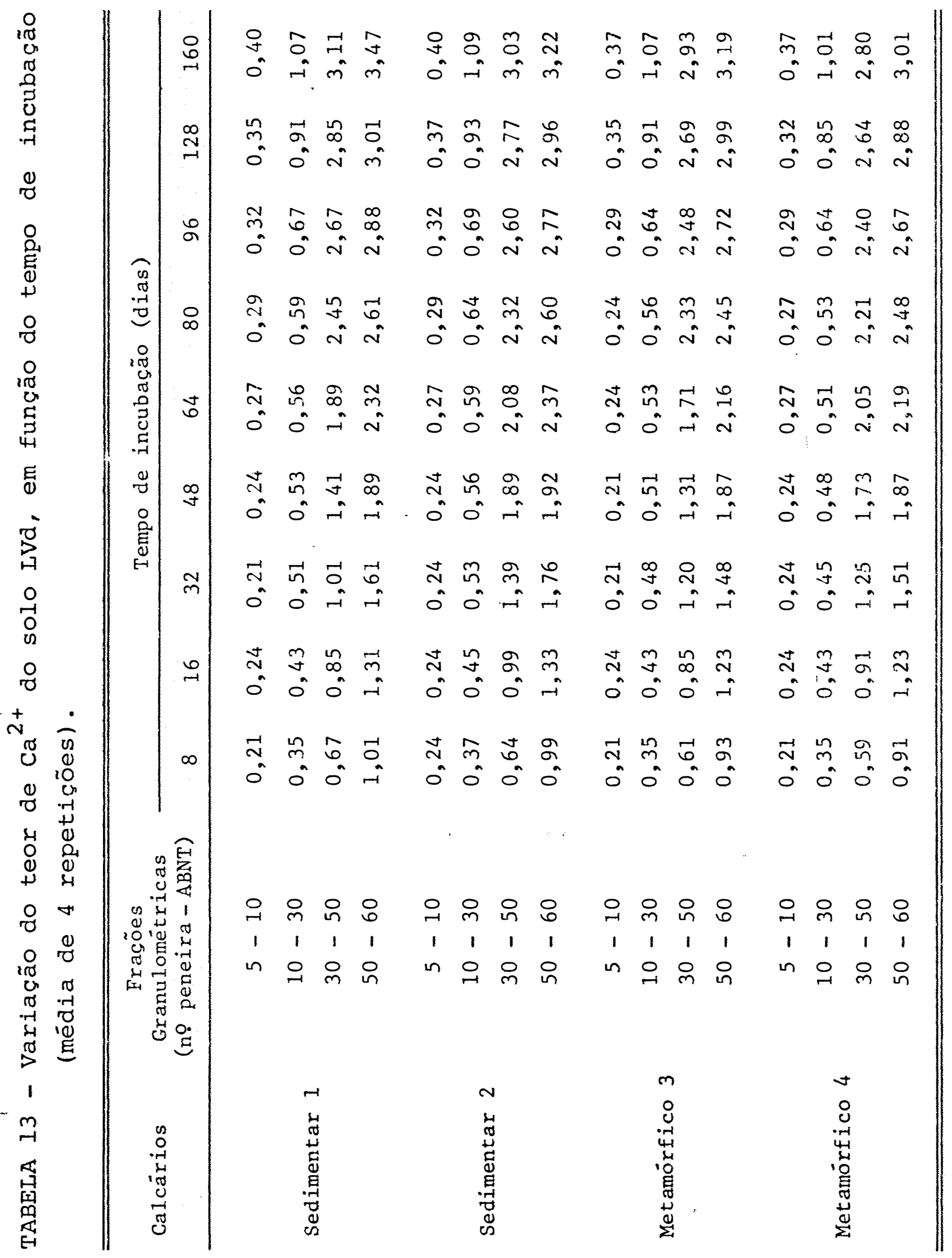



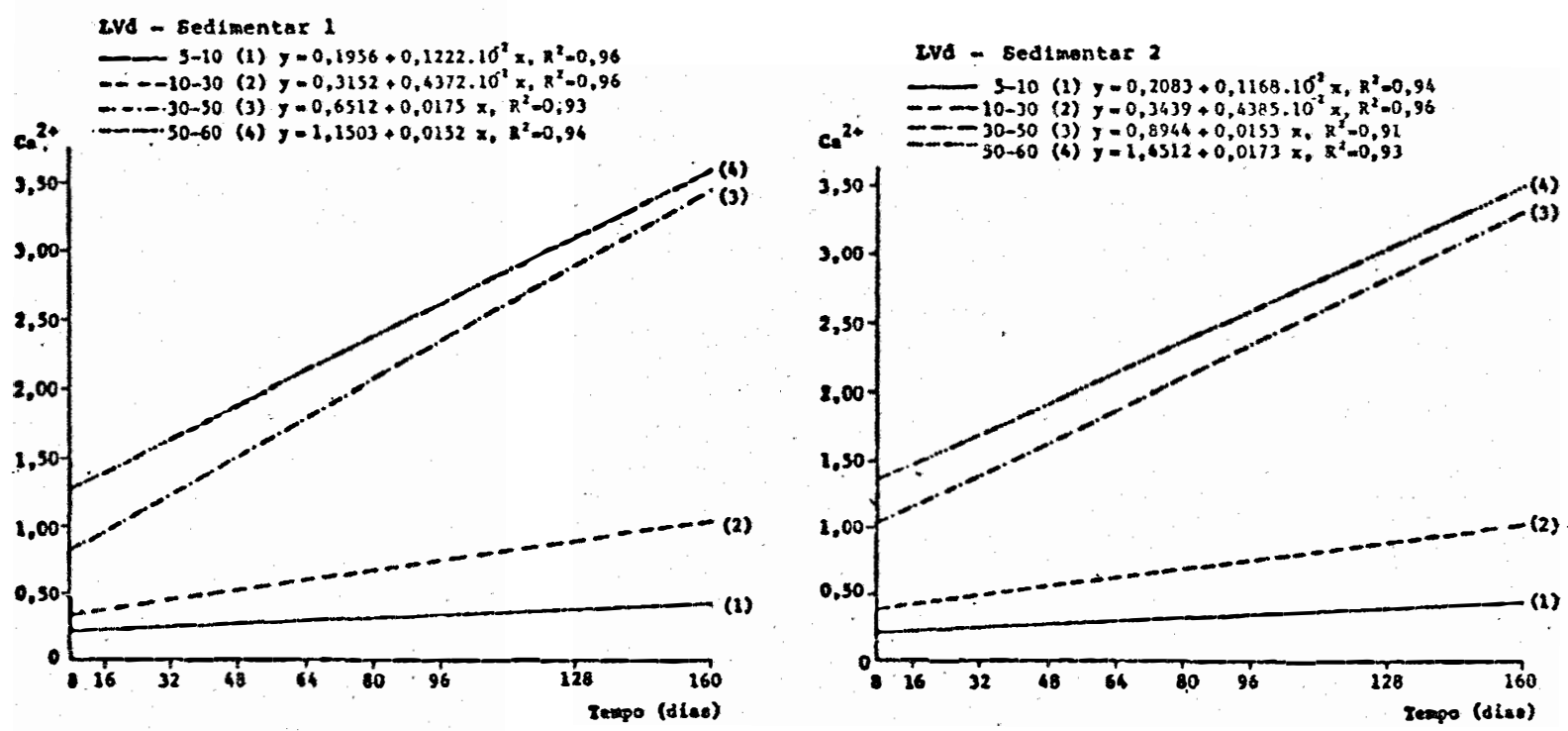

Lva - Metanórfico 3
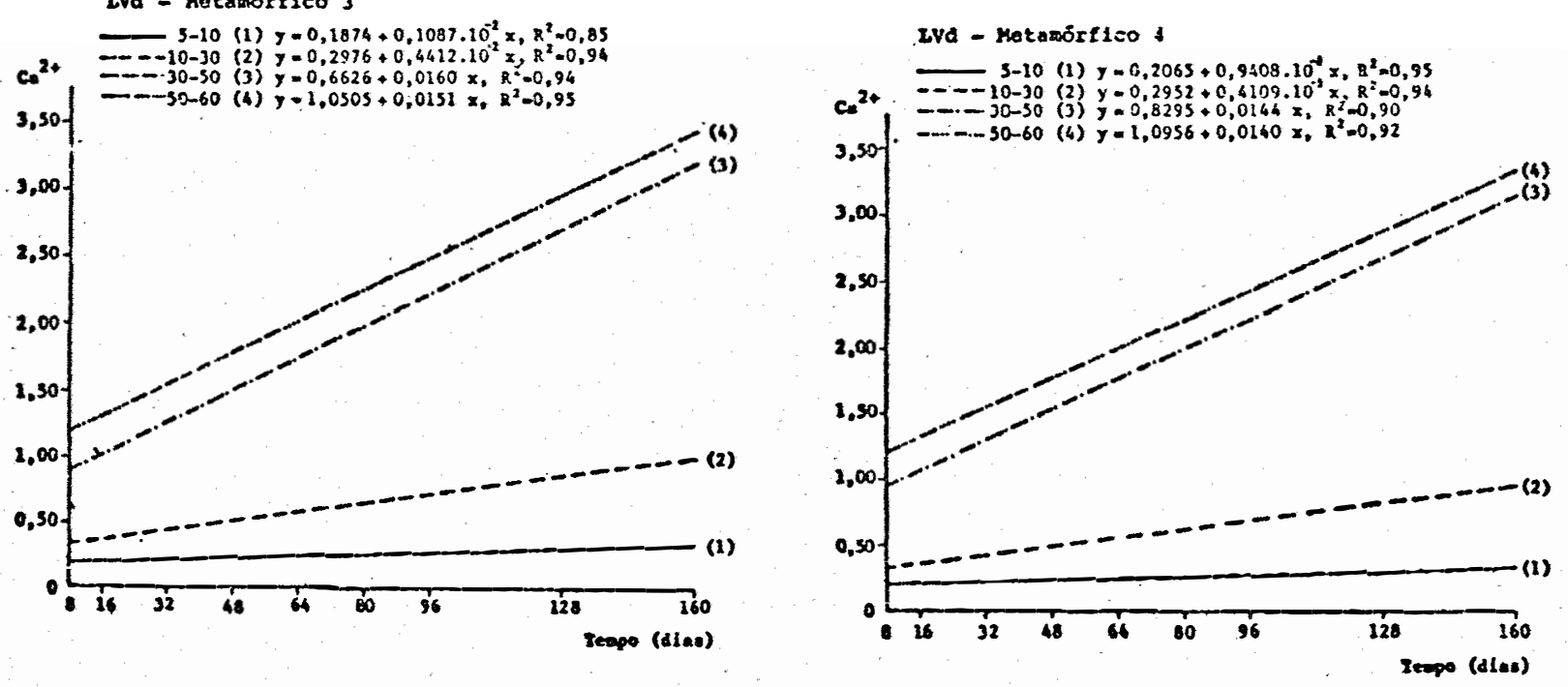

FIGURAS 28 a 31 - Representação gráfica da equação de regressão. polinomial do $\mathrm{Ca}^{2+}$ em função do tempo de incu bação, no solo LVa com os quatro tipos de cal cários. 
muito acentuada, resultados que se aproximaram aos de TEDESCO e ANGHINONI (1980).

0 aumento do teor de $\mathrm{Ca}^{2+}$ foi bastante notado pa ra as frações 30-50 e 50-60, independentemente do calcārio utilizado, porēm.sempre com maiores valores para a granulome tria mais fina (50-60). De uma maneira geral, na fração 30-50 O teor de $\mathrm{Ca}^{2+}$ variou no tempo de 8 dias, de 0,59-0,67e.mg. até 2,80-3,12 e.mg. para 160 dias, valores estes sempre crescen tes e linearesipara a granulometria 50-60, a variação foi de 0,91-1,01 e.mg aos 8 dias até 3,01 ·3,47 e.mg aos 160 dias. Essas reações de efeitos lineares provavelmente aconteceram em fun ção de que a dose de calcário utilizada não foi suficiente pa ra saturar esse solo, pois o seu poder tampão é bastante ele vado, devido ao teor de matēria orgânica $(2,69 \%)$ e o de argi la (37. \%) .

4.3.2. Solo LEd

Na Tabela 14, são encontrados os valores de $\mathrm{Ca}^{2+}$ em função do tempo de incubação e dos quatro tipos de calcá rios com seus diferentes graus de finura.

Na Tabela 07, são apresentados os valores F, para as equações de primeiro, segundo e terceiro grau.

Nas Figuras 32 a 35, são apresentadas, gráfica e ma tematicamente, as equações de regressão obtidas. 


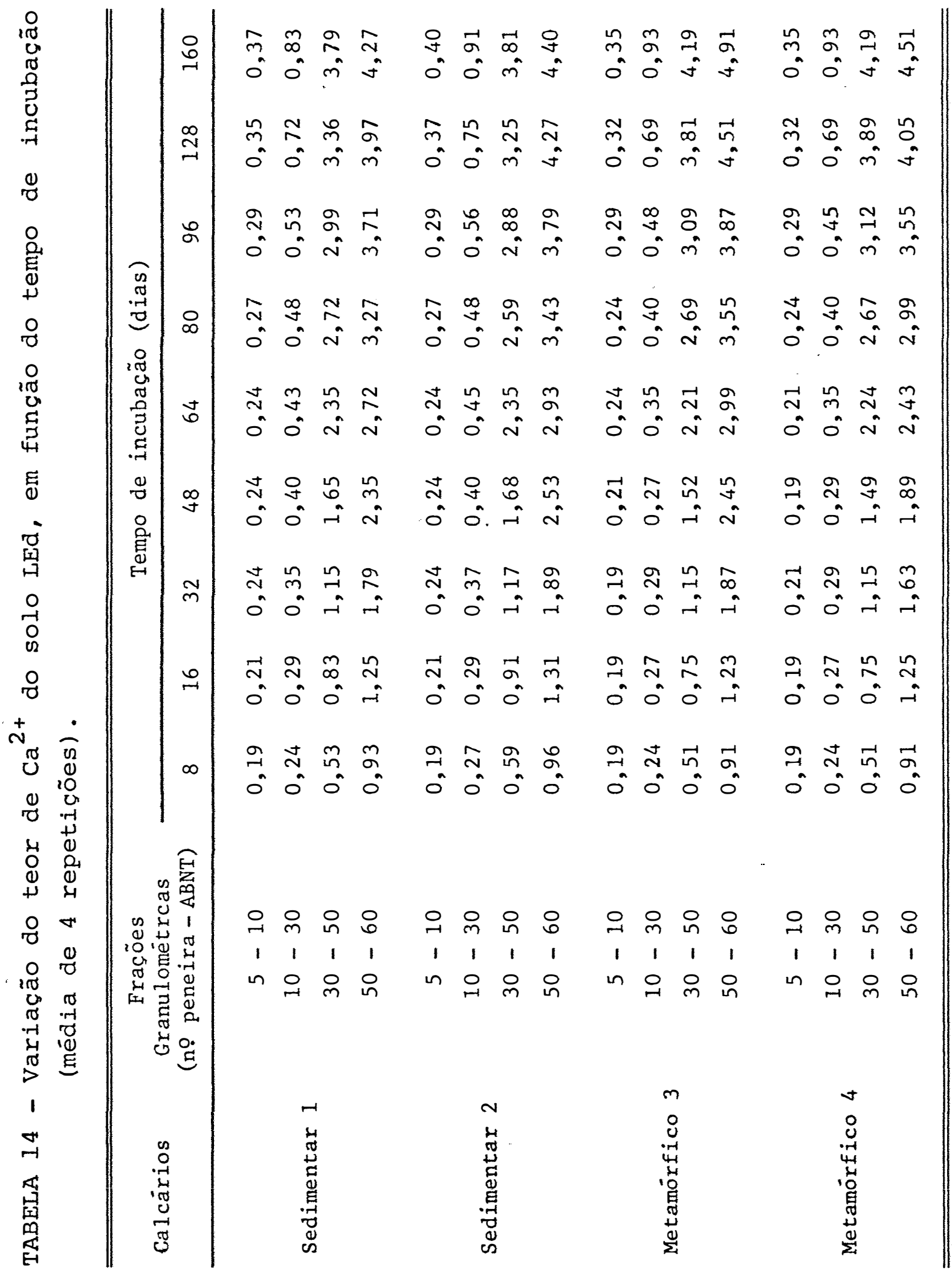



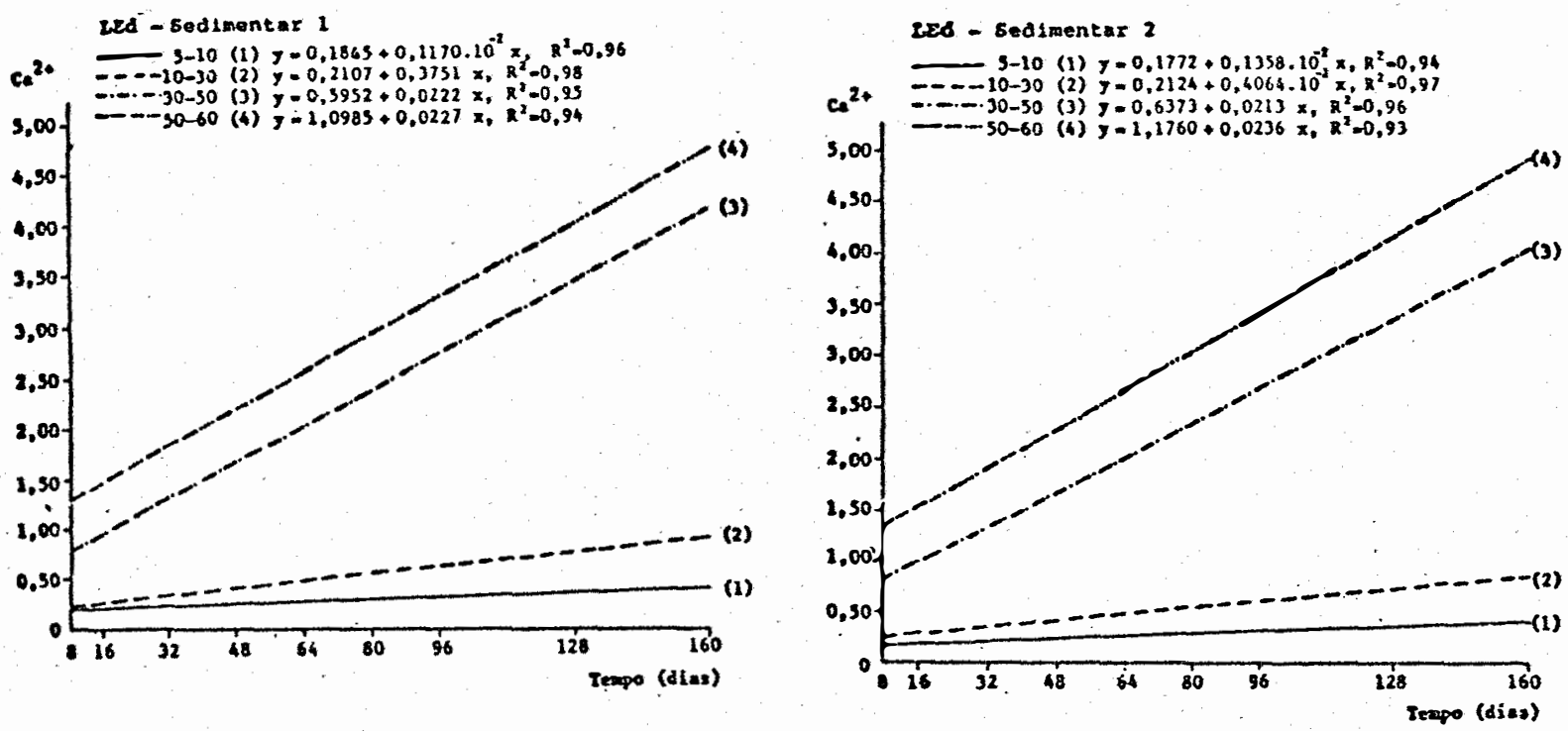

LEd - Metamórfłco

- S-10 (1) $y=0,1641+0,1165 \cdot 10^{-2} x_{2} R^{2}=0,96$ $-=-10-30$ (2) $y=0,1292+0,6362 \cdot 10^{-2} x, R^{2}=0,90$ $6 x^{2+}=-30-50$ (3) $y=0,4082+0,0259 x, R^{2}=0,98$
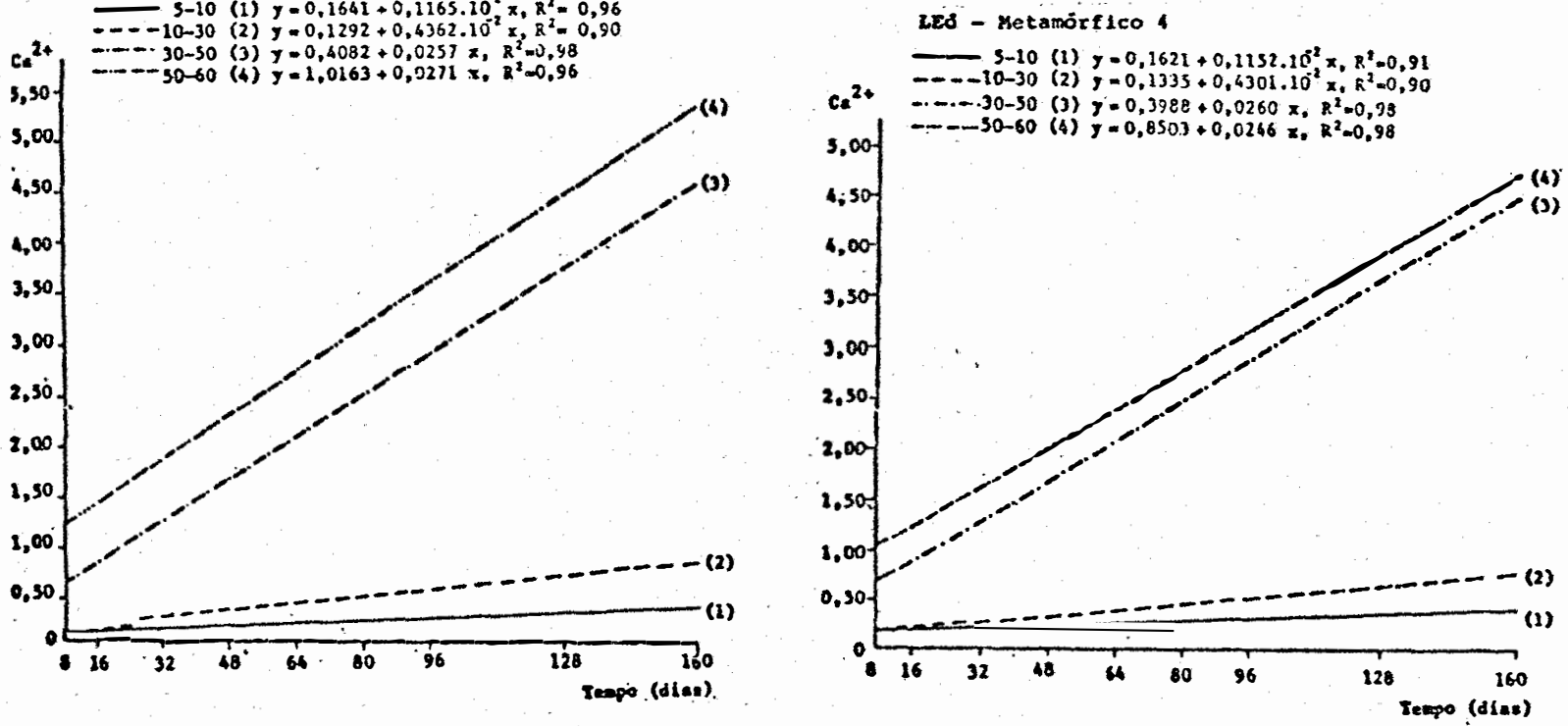

FIGURAS 32 a'35 - Representação gráfica da equação de regressão polinomial do $\mathrm{Ca}^{2+}$ em funçäo do tempo de incu bação, no solo LEd com os quatro tipos de cal cários. 
Em função do solo anterior, nota-se que existe uma semelhança de comportamento dos calcários e de suas granulome trias. As frações grosseiras (5-10 e 10-30), pouco contribui ram para o aumento do teor de $\mathrm{Ca}^{2+}$ do solo até os 160 dias da incubação, tendo,portanto, um valor agronômico bastante baixo.

Os calcários mais fínos tiveram uma reação bastan te acentuada, porēm linear, e sempre a fração 50-60 forneceu mais $\mathrm{Ca}^{2+}$ ao solo que a 30-50. Apesar do solo não ter se equilibrado quanto ao teor de cálcio, pode-se dizer que a va riabilidade do mesmo foi a seguinte: para a fração 30-50, de $0,51-0,59$ e.mg. aos 8 dias, elevou-se para 3,79-4,19 e.mg aos 150 dias e,para a fração 50-60, de 0,91-0,96 e.mg aos 8 dias, para 4,274,91 e.mg aos 160 dias.

\subsubsection{Solo LEa}

Na Tabela 15, s.ão encontrados os valores de $\mathrm{Ca}^{2+}$ em função do tempo de incubação e dos corretivos com suas res pectivas frações granulomētricas.

Na Tabela 07 , são apresentados os valores de F, pa ra as equações de primeiro, segundo e terceiro grau.

Nas Figuras 36 a 39, são apresentadas gráfica e ma tematicamente, as equações obtidas. Pela observação das Figuras 36 a 39 nota-se que, com exceção das granulometrias 30-50 e 


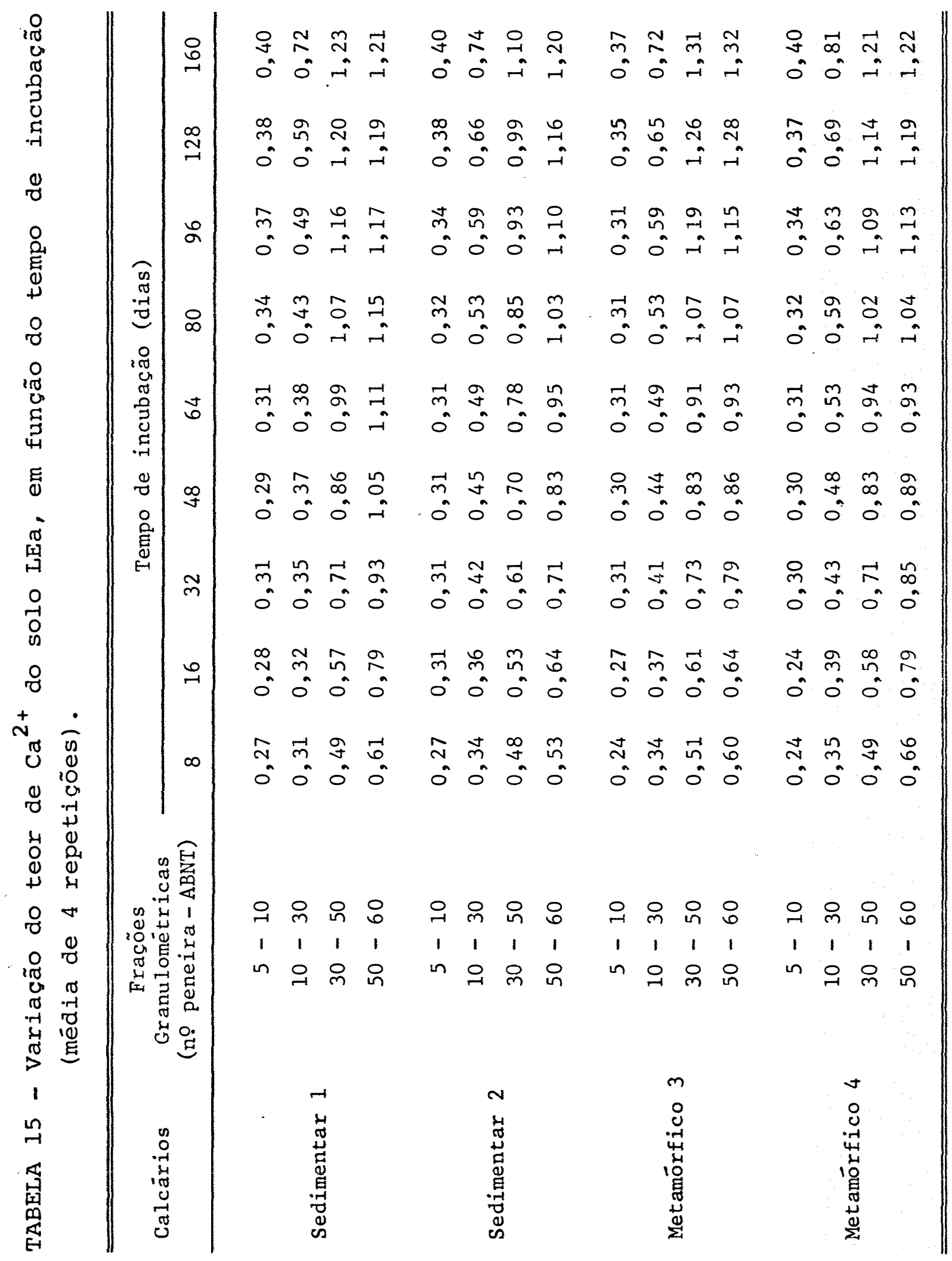



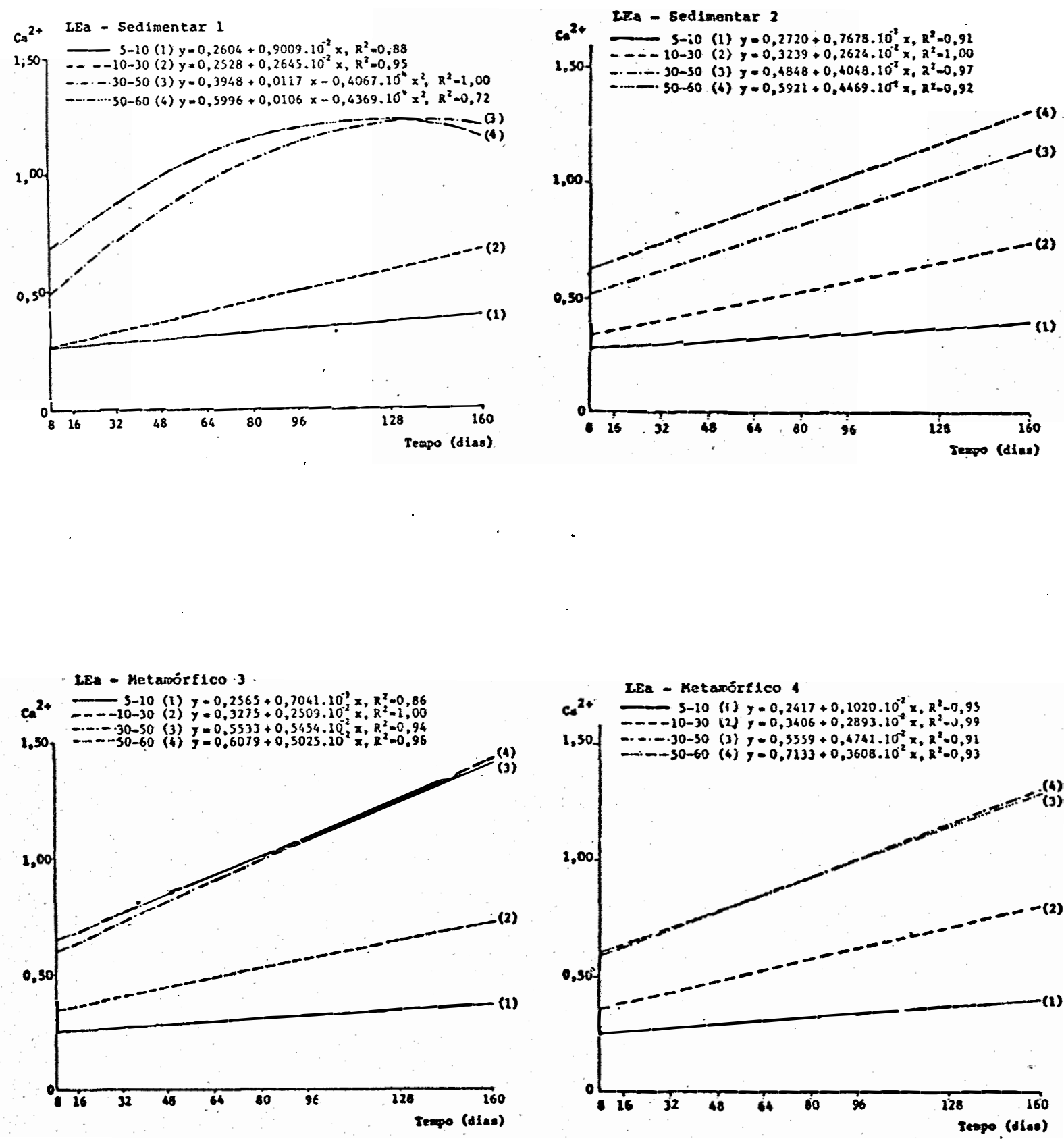

FIGURAS 36 a,39 - Representação gräfica da equação de regressão polinomial do $\mathrm{Ca}^{2+}$ em função do tempo de incu bação, no solo LEa com os quațro tipos de cal cários. 
50-60 do calcário sedimentar-1, as quais foram quadrá ticas, todos os outros três calcários e suas respectivas fra ções granulométricas tiveram efeitos lineares. Pela observa ção dessas curvas, vê-se que as mesmas se cruzam ao redor de 136 dias pois, como o poder tampão desse solo é menor que o do LEd e O LVd, a granulometria 30-50 tende a igualar-se e inclu sive ultrapassar a eficiência da granulometria 50-60 no perío do de 160 dias. As granulometrias mais grosseiras de uma ma neira geral, para todos os calcários, tenderam a dar uma reação ao longo do tempo e isso foi notado em função de que, por me. nor que seja a reatividade dessas partículas (5-10, 10-30), co mo o poder tampão do solo é baixo, essa pequena solubilidade dos calcários é detectada pela anālise química, tendo-se em vista que os mesmos ficam mais disponíveis. Pela Figura 37, vê-se que o calcário sedimentar-2 reagiu também linearmente com o tempo, porém, o mais fino 50-60 teve melhor efeito que a fração menos fina 30-50. Os valores obtidos variaram de 0,53 a 1,20 e.mg. Nas Figuras 38 e 39 , praticamente as retas representativas das frações 30-50 e 50-60 se superpõem, indi cando que em solos arenosos e pobres em matéria orgânica, con seqthentemente com baixo poder tampão, a partir de um certo grau de finura o poder de reação dos mesmos é igual. Para os dois calcários metamórficos esse fato aconteceu, provavelmen te porque a soma dos teores de CaO e MgO para cada calcário foi praticamente igual. 
A variabilidade, incluindo os dois calcários meta mörficos, foi de: 0,48-0,68 e.mg aos 8 dias e 1,20-1,34 e.mg aos 160 dias.

Em relação aos outros' solos, como os teores de car bonatos fornecidos são os mesmos e nesse ensaio não ocorreu lixiviação e nem extração por culturas é de se supor que uma porcentagem desse material não tenha reagido em função do prō prio potencial do solo em solubilizar esses carbonatos.

4.4. Teor de $\mathrm{Mg}^{2+}$

$$
4.4 .1 \text {. Solo LVd }
$$

Na Tabela 16, são encontrados os valores de $\mathrm{Mg}^{2+}$ em função do tempo de incubação e para os calcários com seus diferentes graus de finura.

Na Tabela 07, são apresentados os valores de F, pa ra as equações de primeiro, segundo e terceiro grau.

Nas Figuras 40 a 43 , são apresentadas gráfica e ma tematicamente, as equações obtidas. Excetuando as equações quadráticas obtidas para o calcário metamōrfico-3 em suas fra ções granulométricas 5-10 e 50-60, todas as demais equações fo ram lineares, demonstrando, como para $\circ \mathrm{Ca}^{2{ }^{+}}$, uma condição de não equilíbrio químico no solo. Sempre as frações mais gros seiras (5-10, 10-30) tiveram pouca eficiência no fornecimento de $\mathrm{Mg}^{2}$ ao solo, inclusive com uma inclinação da reta bastan 


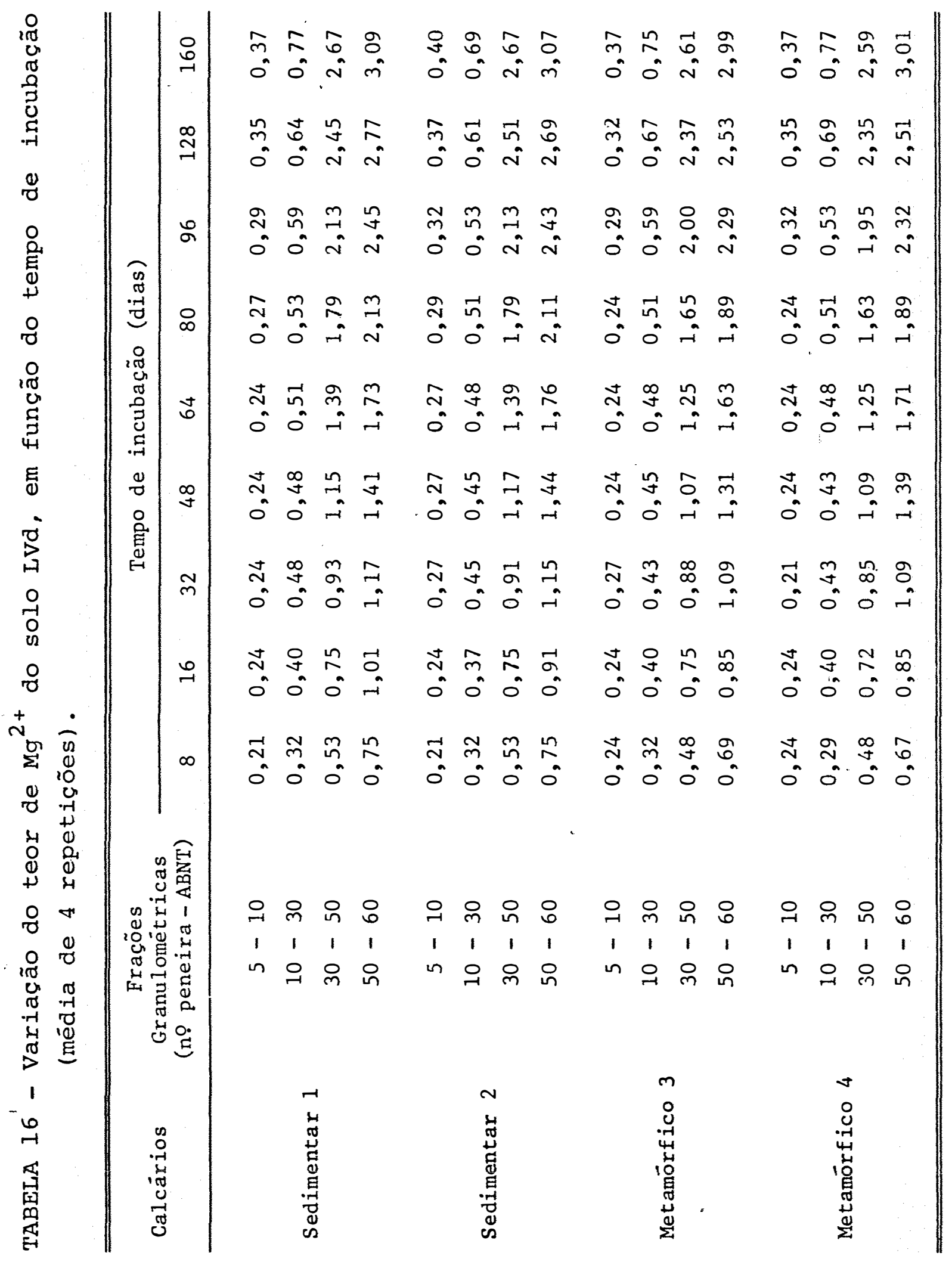



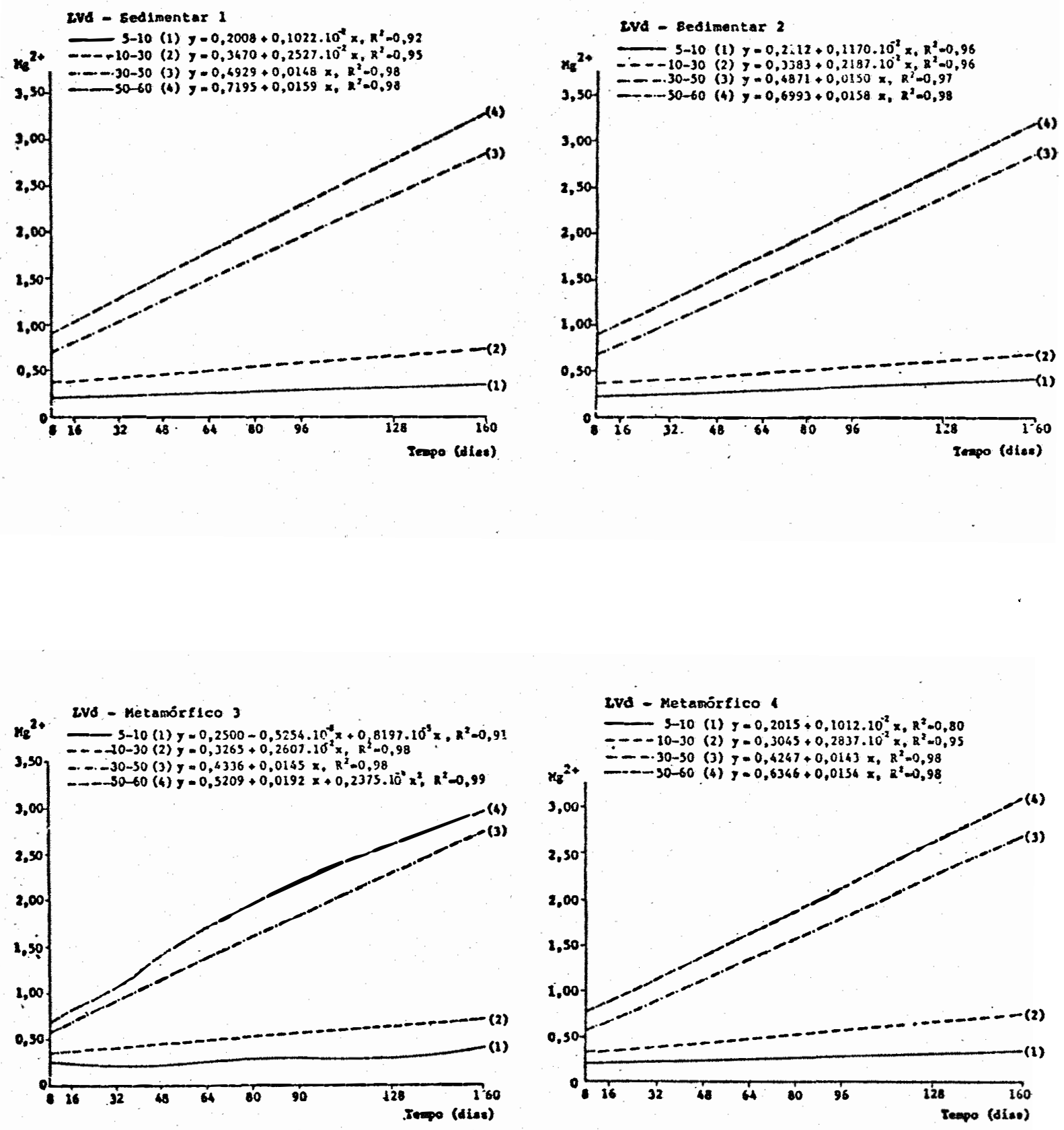

FIGURAS 40 a 43 - Representação gráfica da equação de regressão polinomial do $\mathrm{Mg}^{2+}$, em função do tempo de in cubação, no solo LVa com os quatro tipos de calcários. 
te baixa em relação às abcissas, demonstrando que os valores determinados aos 8 dias não são muito diferentes daqueles ob tidos aos 160 dias. Porém, ao se utilizar as granulometrias mais finas, a inclinação da reta se acentua e a diferença de concentração inicial ( 8 dias) e final (160 dias) é mais ampla. Os valores mëdios dessa variabilidade foram: para a fração 30-50, de $0,48-0,56$ e.mg aos 8 dias para $2,56-2,78$ e.mg aos 160 dias e para a fração 50-60, de 0,64-0,80 e.mg aos 8 dias para 2,96-3,12 e.mg aos 160 dias, resultados semelhantes aos de TEDESCO e ANGHINONI (1980).

\subsubsection{Solo LEd}

Na Tabela 17, encontram-se os valores de $\mathrm{Mg}^{2+}$, em função dos tempos de incubação, dos tipos de calcários e de suas granulometrias.

Na Tabela 0.7, são apresentados os valores de F, pa ra as equações de primeiro, segundo e terceiro grau.

Nas Figuras de 44 a 47 ,são apresentadas gräfica e matematicamente, as equações obtidas.

De uma maneira geral, existe uma semelhança de com portamento entre os diferentes calcários,com seus diferentes graus de finura,no fornecimento de $\mathrm{Mg}^{2+}$ para o solo LEd e pa ra o LVd,que já foi anteriormente explicado.

Sempre a reação foi mais eficiente, e em ordem cres 


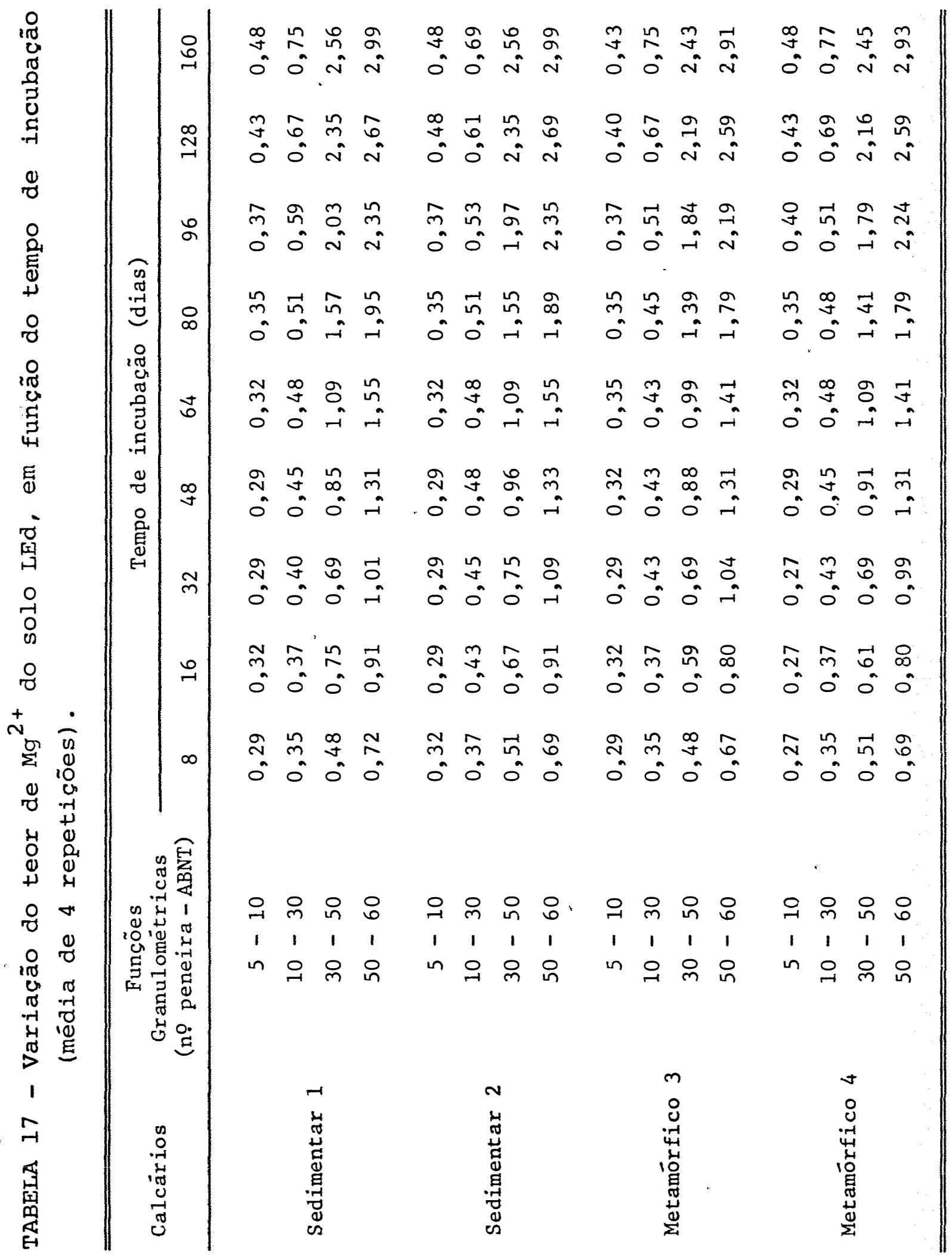



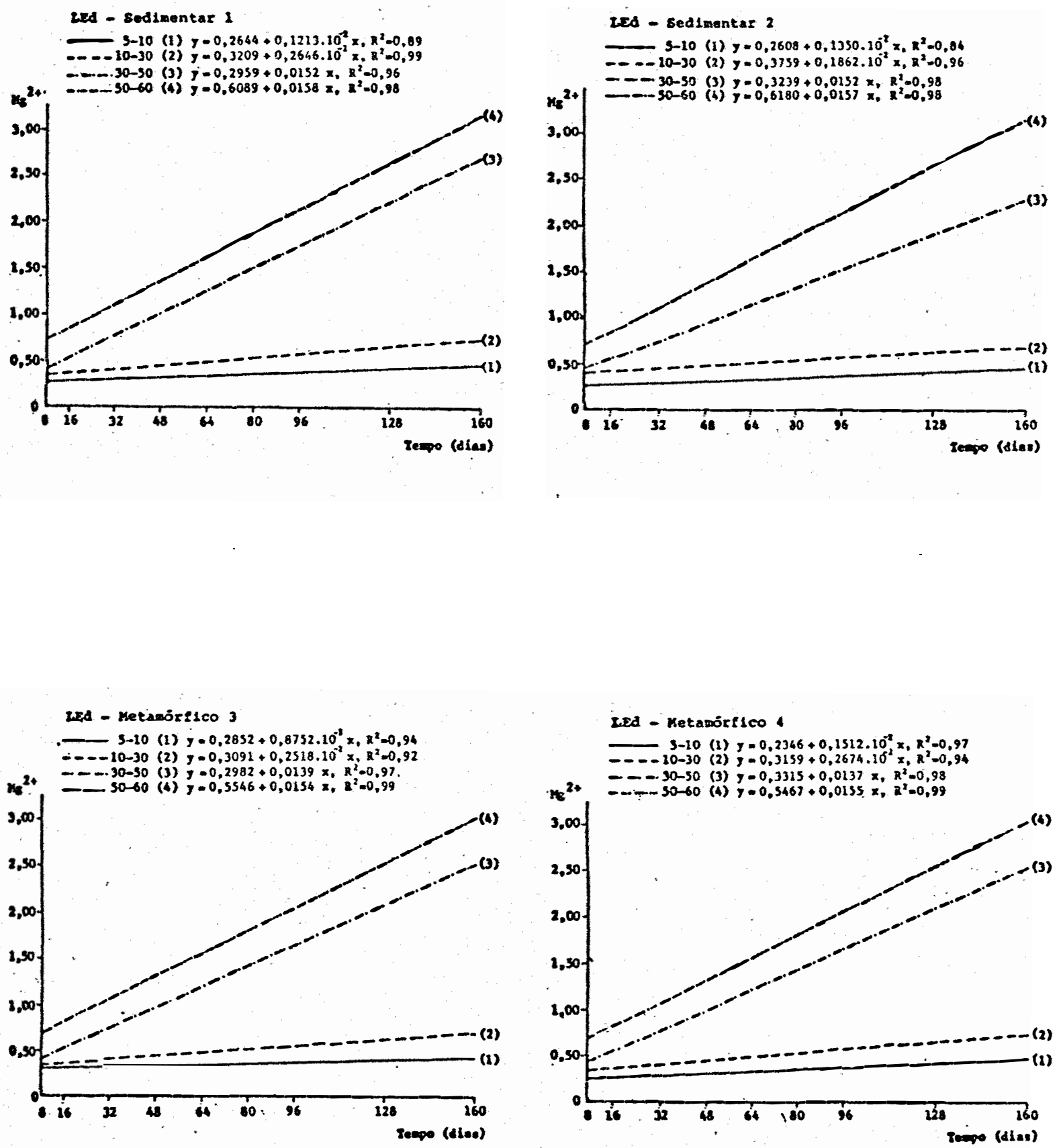

FIGURAS 44 a 47 - Representação gráfica da equação de regressão polinomial do $\mathrm{Mg}^{2+}$, em função do tempo de in cubação, no solo LEd com os quatro tipos de calcārios. 
cente, das frações mais grosseiras (5-10, 10-30) para as mais finas $(30-50,50-60)$. As mais grosseiras não elevaram os teo res de $\mathrm{Mg}^{2}$ em função do tempo e do tipo de calcário, porēm, as mais finas tiveram, ao longo do tempo, um comportamento mais efetivo, ou seja, fornecendo mais $\mathrm{Mg}^{2+}$ ao solo. A variabilidade nas trocas iniciais ( 8 dias) e finais (160 dias), independentemen te do tipo de calcário foram: para a fração 30-50 de . 0,480,50 e.mg para 2,43-2,56 e.mg e,para a fração 50-60, de 0,67-0,72 e.mg para $2,91-2,29 \mathrm{e} . \mathrm{mg}$.

Não se deve esquecer que esses efeitos lineares in dicam que não foi obtido o equilíbrio químico do solo, o que poderia ser explicado pela não dissolução total do carbonato de magnésio contido no calcário.

\subsubsection{Solo IEa}

Na Tabela 18, são encontrados os valores de $\mathrm{Mg}^{2}{ }^{+}$, em função do tempo de incubação, dos diferentes calcários com as diversas frações granulométricas.

Na Tabela 0.7, são apresentados os valores de $\mathrm{F}$, pa ra as equações de primeiro, segundo e terceiro grau.

Na Figuras 48 a 5l, são apresentadas gráfica e ma tematicamente, as equações obtidas. Pela observação dessas Fí guras, nota-se que,para as frações granulométricas grosseiras 5-10 e 10-30, as retas chegam a se sobrepor no início da incu 


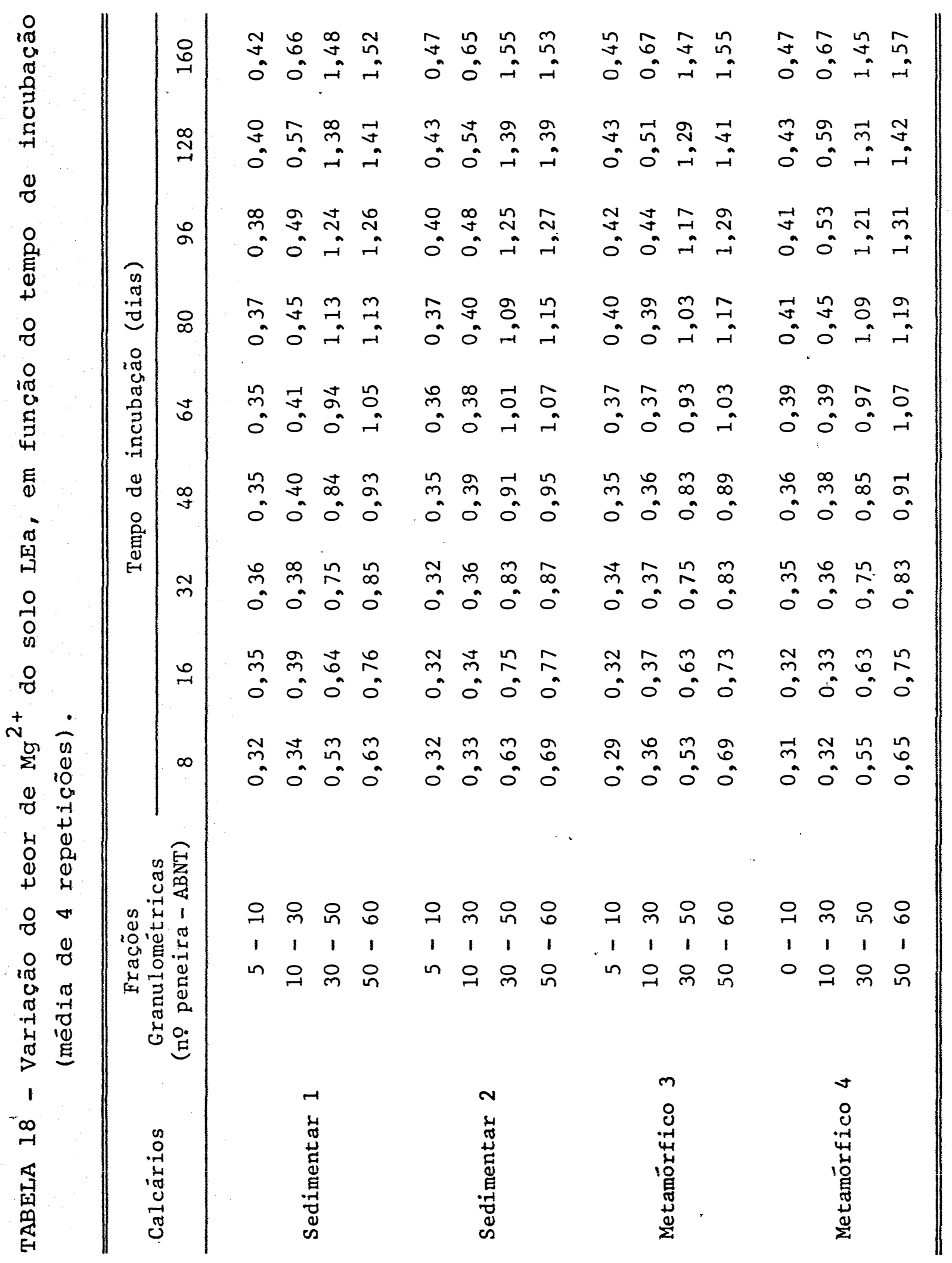



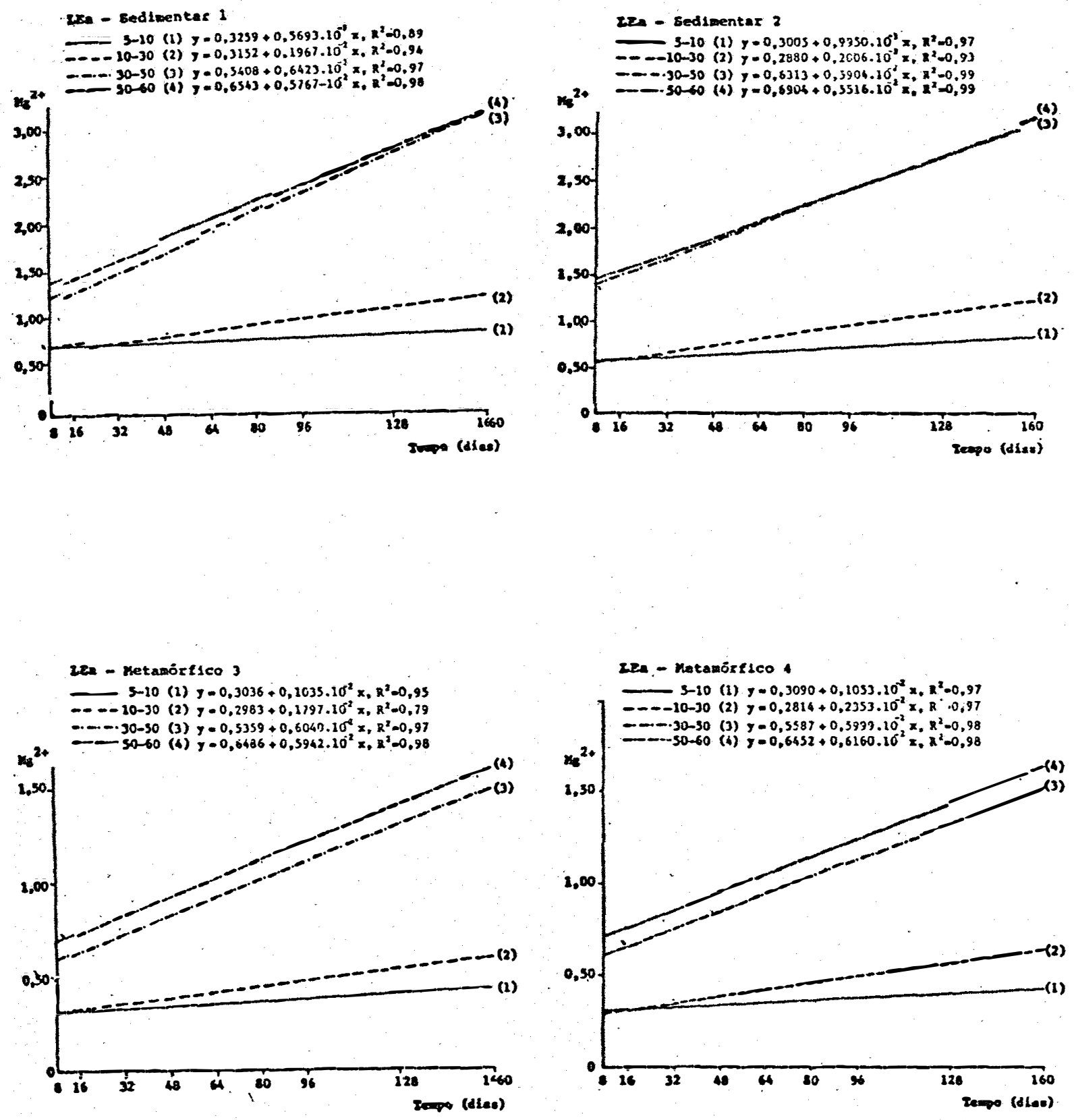

FIGURAS 48 a 51 - Representação grāfica da equação de regressão polinomial do $\mathrm{Mg}^{2+}$, em função do tempo de in cubaçäo, no solo LEa com os quatro tipoș de calcārios. 
bação (até \pm 32 diasl e,a partir desse tempo, a fração 5-10. fornece pouco $\mathrm{Mg}^{2+}$ aó solo, porêm a 10-30 apresenta uma maior diferenciação, atingindo o máximo aos 160 dias. Apesar desse aspecto, o valor agronōmico da fração 10-30 não é viāvel deví do ao tempo decorrido apōs a incubação. Quanto às frações 30-50 e 50-60, as mesmas são praticamente superpostas para os dois tipos de calcārios sedimentares e,para os dois tipos de meta mórficos, as duas curvas são praticamente paralelas e bastante próxí mas .

Esses fatos, vêm novamente afirmar o que já foi di to em função do poder tampão desse solo, pois, a eficiência dos calcários além de ser bastante semelhante; chegam a se igualar para as frações 30-50 e 50-60.

Dentro de valores mëdios; pode-se dizer que; para a fração 30-50, a variabilidade aos 8 dias foi de 0,53-0,63 e.mg a 1,47-1,55 e.mg aos 160 dias. para granulometria 50-60 foi de 0,63-0,69 e. mg aos 8 dias para 1,52-1,57 e.mg aos 160 dias. Ao se observar esses va lores,pcde-se dizer que os mesmos são semelhantes em função de seu uso agronômico, pois a variabilidade entre eles, quer no início quer no fim da incubação,è bastante próxima.

- 4.5. Estudo das Interações entre Solos, Calcários e Frações Granulométricas

Fez-se a anālise de variāncia auxiliar para se de 
terminar os valores do teste $F$ para as interações Solos $x$ Cal cārios, Solos x Frações. e Calcārios x Frações, para pH, $\mathrm{Ca}^{2+}$, $\mathrm{Mg}^{2+}$ e $\mathrm{Al}^{3^{+}}$e para as, 09 épocas de estudo. Nos efeitos signi ficativos obtidos fizeram-se todos os desdobramentos possíveis, e pelos dados obtidos, observou-se que sempre a interaçãosolos $\mathrm{x}$ Frações foi significativa para qualquer época ou para qualquer determinação feita. Disso se pressupõesque no estudo da reatí vidade dos calcários, o mais importante é o efeito das frações granulométricas, independentemente do tipo de calcário, e is to, em função de cada solo. Dentro de um contexto,as proprie dades de um solo não se alteram com facilidade, porém um grau de moagem dos calcārios é facilmente obtido, pois, nota-se pelas ana lises químicas apresentadas (Tabela 05), que a diferença dos teo res totais de óxidos dos corretivos não é elevada. Em função do exposto, deveria ter-se,para cada solo, reações diferentes para uma mesma fração granulométrica, mas isso è inaplicá vel. Portanto, o adequado è se determinar o Poder Relativo de Neutralização Total (PRNT) de um calcário não se levando em conta a reação desse material em cada tipo de solo.

4.6. Estimativa da Eficiência Relativa das Frações Granulo métricas

Nas Tabelas 06,08 e 09 estão apresentados os dados de variação do pH obtidos nos 3 solos, incubados com os quatro 
tipos de calcários nas suas diferentes frações granulométri cas. E importante notar que após 12 semanas, aproximadamente, a fração 50-60, e apenas ela, de todos os calcārios proporcio nou a elevação do pH para 6,5 nos três solos estudados. Isso, em primeiro lugar, vem ao encontroda recomendação dada à prā tica da calagem, isto é, deve ser feita com três meses de an tecedência; também, essa confirmação sugere o uso dessas con dições, isto é, a fração que passa na peneira 50 eleva $\circ \mathrm{pH}$ dos solos para 6,5 em 12 semanas como parâmetro de referência, atribuindo-lhe a eficiência de $100 \%$.

Em funçãodesse parâmetro pode-se calcular a efí ciência relativa das demais frações granulométricas conside rando os acréscimos ocorridos no pH dos solos nesse período. Os valores obtidos estão contidos na Tabela 19, tendo sido considerado como pH original dos solos o valor obtido pela mé dia dos valores determinados durante todo o experimento, is to é, 5,20 para o solo LVd; 5,24 para o LEd e 4,99 para ○. LEa. Deve ser ressaltada a consistência da média das eficiências, considerando os três solos, dentro de cada fração granulomé trica dos diferentes calcārios.

Conforme evidenciam os dados das Tabelas $06,0.8$ e 09, a reatividade dos calcârios é bastante influenciadá pelo tipo de solo, sendo decrescente na seguinte ordem: LEd, LVd e LEa. Por outro lado, a reatividade não mostrou qualquer depen dência da natureza geológica dos calcários, isto é, tanto os 
TABELA 19 - Eficiēncia relativa (ㅇ) das diferentes frações granulométricas dos calcários nos vários solos, apōs 12 semanas de incubação.

Calcários

Fração Granulométrica

Solos

\begin{tabular}{|c|c|c|c|c|c|}
\hline & (Peneira no ABNT) & LVd & LEd & LEa & Média \\
\hline \multirow{4}{*}{$s-1$} & $5-10$ & 10,0 & 6,9 & 4,1 . & 7,0 \\
\hline & $10-30$ & 43,8 & 41,1 & 27,7 & 37,5 \\
\hline & $30-50$ & 90,0 & 79,8 & 79,8 & 76,4 \\
\hline & $50-60$ & 100,0 & 100,0 & 100,0 & 100,0 \\
\hline \multirow{4}{*}{$s-2$} & $5-10$ & 9,5 & 9,8 & 5,4 & 8,2 . \\
\hline & $10-30$ & 41,6 & 44,4 & 32,4 & 39,5 \\
\hline & $30-50$ & 82,5 & 77,4 & 68,2 & 76,0 \\
\hline & $50-60$ & 100,0 & 100,0 & 100,0 & 100,0 \\
\hline \multirow{4}{*}{$M-3$} & $5-10$ & 9,8 & 4,7 & 1,3 & 5,3 \\
\hline & $10-30$ & 39,8 & 41,1 & 27,2 & 36,0 \\
\hline & $30-50$ & 85,0 & 84,5 & 64,9 & 78,1 \\
\hline & $50-60$ & 100,0 & 100,0 & 100,0 & 100,0 \\
\hline \multirow{4}{*}{$M-4$} & $5-10$ & 15,0 & 12,0 & 0,7 & 9,2 \\
\hline & $10-30$ & 47,4 & 39,8 & 25,2 & 37,5 \\
\hline & $30-50$ & 77,4 & 85,0 & 66,9 & 76,4 \\
\hline & $50-60$ & 100,00 & 100,00 & 100,00 & 100,00 \\
\hline
\end{tabular}


de origem sedimentar como os de origem metamórfica apresenta ram reatividades muito semelhantes.

Na Tabela 20 estão apresentados as eficiências re lativas mēdias calculadas para cada fração granulomētrica, a partir dos resultados obtidos em cada calcārio: Levando-se em conta a reação relativamente baixa dos resultados apre sentados pela fração 5-10 e adotanão: um intervalo de confiança, sugere-se que se possa atribuir, de maneira geral, os valores também apresentados na Tabela 20 para as eficiên cias relativas das referidas frações granulométricas de calcạa rios.

TABELA 20 - Sugestões para as eficiências relativas (ER\%) obti das para as diferentes frações granulométricas dos calcários (mēdia de 4 repetições).

Frações E.R. $\quad$ Frações $\quad$ E.R.

Granulométricas Obtidas(\%) Granulométricas Sugeridas (\%)

$\begin{array}{rrrr}5-10 & 7,4 & >10 & 0 \\ 10-30 & 37,6 & 10-30 & 35 \\ 30-50 & 76,7 & 30-50 & 75 \\ 50-60 & 100,0 & <50 & 100\end{array}$




\section{CONCLUSÕES}

Nas condições do experimento, os dados permitem concluir que:

1- a reatividade dos calcários nos três tipos de solo independe da natureza geológica dos calcários;

2- a reação dos calcários, varia nos diferentes tị pos de solo;

3- sugerem-se os seguintes valores para a eficiên cia relativa de diferentes fraçöes granulométricas de calcá rios: fração maior do que 10 (no peneira-ABNT) =0\%; de 10 a $30=35 \%$; de 30 a $50=75 \%$ e menor do que $50=100 \%$.

Assim a expressão para o cálculo do PRNT dos cal cārios seria: 
$\therefore \mathrm{E}_{\mathrm{CaCO}_{3}}\left(\mathrm{~A}_{10-30} \times 0,35+\mathrm{A}_{30-50} \times 0,75+\mathrm{A}_{<50} \mathrm{x} 1,0\right)$

100

onde,

${ }^{8} \mathrm{E}_{\mathrm{CaCO}_{3}}=$ porcentagem de óxidos de cálcio e magnésio, expressa em equivalente de $\mathrm{CaCO}_{3}$.

$A_{10-30}=$ porcentagem da fração retida entre as peneiras io e 30.

$A_{30-50}=$ porcentagem da fração retida entre as peneirás 30 e 50

$A_{<50}=$ porcentagem da fração que passa na peneira 50. 
6. LITERATURA CITADA

A.A.P.F.C.O., 1976. Association of American Plant Food Con trol officials. Columbia, University of Missouri. . (Offi cial Publications, 29).

ABRUÑA, F.R.; J.V. CHANDLER; R.W. PEARSON e S. SILVA, 1970 Crop response to soil acidity factors in Ultisol and oxi sols. I: Tobaco. Proceedings Soil science Society of America, Wadison, 34(4):629-32.

ALCARDE, J.C., 1982. Características de qualidade dos correti vos da acidez do solo. In: 150 Simpósio Sobre Acidez e Cala gem, Campinas, $12 \mathrm{p}$.

A.O.A.C., 1980. Official Methods of Analysis. 13. ed. Wa shington, Association of Official Analytical Chemists,p 1-6. BARBER; S.A., 1967. Liming materials and practices. In: PEAR SON, R.W. e ADAMS, F. Soil Acidity and Liming. Wadison, American Society of Agronomy, p.125-60.

BEACHER, R.L.; D. LONGENEKER e F.G. MERKLE, 1952. Influence of form, fineness, and amount of limestone on plant develop ment and certain soil characteristics. Soil Science, Balti 
more, $73: 75-82$.

BEAR, F.E. E S.J.TOTH, 1952. The pH values and lime require ments of 20 New Jersey soils. Circular off New Jersey Agri culture Experimental Station, no 446 .

BOHNEN, H. e W. WUNSCHE, 1972. Determinação da reação do cal cário, através do estudo da sua composição granulométrica : Relatório de Pesquisa para o CNPq. Porto Alegre, UFRGS, Departamento de Solos. 12p. (Não Publicado) .

BORKERT, C.M., 1973. Efeito do calcärio e do cloreto de potás sio sobre as concentragões de manganès e aluminio nos oxis solos Santo Angelo e passo Fundo e suas relagões com a nodu Zagão e rendimento de duas cultivares de soja. Porto Ale gre, UFRGS. Faculdade de Agronomia, 37p. (Tese de Mestra do) .

BOYNTON, R.S., 1965. Chemistry and Technology of Lime and Li mestone. New York, Interscience. 520p.

BRAGA, J.M.; L.S. BRAGA eL.A.N., FONTES, 1971 . Efeito da apli cação do calcário sobre os níveis de pH, cálcio, magnésio, fósforo e potássio do solo. Revista Ceres, Viçosa,27: 279-93 .

BRASIL. Leis e Decretos, 1982. Decreto n! 86.955 de $18 / 02 /$ 11982, Portaria n? 01 de 20/04/1982 e Portaria n! 031 de 08 106/1982 do Ministério da Agricultura. Brasília, DF.

CATANI, R.A. e O. ALONSO, 1969. Avaliação da exigência de cal cário do solo. Anais da Escola Superior de Agricultura "Luiz de Queiroz", Piracicaba,26:141-56. 
COLEMAN, N.T., 1962. II - Decomposition of clays and the fade of aluminium. Economic Geology, Lancaster, Pa - USA, 57: $1207-18$

COLEMAN, N.T., G. W. THOMAS, F.H. LE ROUX e G. BREDELL, 1964. Salt exchangeable and titratable acidity in Bentonite-sesquio xide mistures. Proceedings Soil Science. Society of America Madison, $28(1): 35-7$.

COLEMAN, N.T. E G.W. THOMAS, 1967. The basic chemistry of soil acidity. In: PEARSON, R.W. e ADAMS, F. ed. Soil Aci dity and Liming. Madison, American Society of Agronomy, p. 1-41. (Agronomy Series, 12).

COMISSÃO DE SOLOS. 1960. Levantamento de reconhecimento dos solos do Estado de São Paulo. São Paulo, Serviço Nacional de Pesquisas Agronômicas. (Boletim, 12).

ELPHICK, B.L. 1955. Studies in use of agricultural limes to ne: II - Solubility of limestone in acid soil as influen ced by particle size. New Zeland. Journal of Science and Technology, Wellington, $37(2): 156-73$.

FREITAS, L.M.M., P.F. PRATT e L. VETTORI, 1968. Testes rápidos para estimar as necessidades em calcário de alguns so los de São Paulo. Pesquisa Agropecuaria Brasizeira, Rio de Janei ro, $\underline{3}:$ : 159-64.

FRINK, C.R. E M. PEECH; 1963. Hydrolisis and exchange reac tions of the aluminum ion in the bentomite and montemori lonite suspentions. Proceedingo soil Science Society of Ameri rica Madison, 27(5):527-30. 
GALIO, J.R. e R.A. CATANI, 19.54. Solubilidade de alguns tipos de calcários. Bragantia, Campinas, 13:63-74.

GALLO, J.R.; R.A. CATANI e H. GARGANTINI, 1956. Efeito de três tipos de calcário na reação do solo e no desenvolvimen to da soja. Bragantia, Campinas, 15:121-30.

GARGANTINI, H. 1974. Efeitos da granulometria formas e quan tidades de materiais corretivos na acidez do solo. Bragan tia, Campinas, 33: 87-96.

GARGANTINI, H.eH.G. BLANCO, 1965. Absorçào de nutrientes pe la cultura do arroz. Bragantia, Campinas,24(38):515-19. GARGANTINI, H., A.G. GOMES e H.G. BLANCO, 1965. Modos de aplí cação ao solo de materiais corretivos na acidez. Bragantia, Campinas, 24: 40 3-10.

GOMES, A.G.; H. GARGANTINI, H.G. BLANCO, 1965. Comportamento de tipos de escórias de siderurgia como corretivo da acidez do solo. Bragantia, Campinas, 24 (15):173-79.

GOMES, A.G.; H. GARGANTINI, G. GUIMARÃES e A.C.P. WUTKE, 1962. Competição entre materiais corretivos (escōrias de siderur gia $x$ calcáriol em solos de várzea do vale do Paraíba. Bra gantia, Campinas, 21: 778-92.

HEDDLESON, M.R.; E.O. MCLEAN e N. HOLONAYCHUK, 1960. Alumi nium in soils. IV. The role of aluminium in soil acidity. Proceedings Soil Science Society of America, Madison, 24(1):91-4. HOYT, P.B. e IJYBORG, M., 1971. TOXic metals in acid soils: I - Estimation of plant available aluminum. Proceedings Soil Science Society American, Madison, 35(2):236-40. 
JACKSON, M.L., 1963. Aluminum bonding in soils: A unifying principle in soil science. Proceedings Soil Science Socie ty of America, Madison, 27(1):1-9.

JACKSON, W.A., 1967. Physiological effects of soil acidity. In: PEARSON, R.W. e ADAMS, F. ed. Soil Acidity and Liming. Madison, American Society of Agronomy, p.43-124 (Agronomy Series, 12) .

JENNY, H. 1961. Refletıons on the soil acidity merry-go-round Proceedings Soil Science Society of America, Madison, 25 (4): $428-31$

KAMPRATH, E.J., 1967. A acidez do solo e calagem. Madison, Wisc., International Soil Testing. 23p. (Boletim Tẽcnico, 4).

KAMPRATH, E.J., 1970. Exchangeable aluminum as a criterion for liming leached soils, mineral soils. Proceedings Soiz Science Society of America, Madison, 34(2):252-54.

KENNEY, D.R. e R.B. COREY, 1963. Factors affecting the lime requirement of Wisconsin soils. Proceedings Soil Science of America: Madison, 27 (3):277-80.

LEON, A.S., 1971. Teorias modernas sobre la naturaleza de la acidez del suelo. Suelos Equatoriailes, "acidez y encalami ento en el tropico". In: 3. Colōquio de Suelos, Medellin, Colombia, Sociedad Colombiana de la Ciencia del Suelo, v.l. $\mathrm{p} \cdot 1-23$

LEPSCH, I.F., I.C. ROTTA e A. KUPPER, 1968. Estudos dos mate riais calcários usados como corretivo do solo no Estado de 
São Paulo. I. Composıção granulometrica. Bragantia, Campi nas, $27: 225-237$.

LOVE, J.R., R.B. COREY e C.C. OLSEN, 1960. Effect of particle size and rate of aplication of dolomitic limestone on soil pH and growth of alfafa. INF. CONGRESS OF SOIL SCIENCE, $7^{\text {th }}$, Madison, 3: 29 3-300.

MALAVolta, E., 1967. Manual de Quimica Agricola. São Pau 10, Ceres. $606 \mathrm{p}$.

MCLEAN, E.O., 1965. Aluminum. In: BLACK, C.A. et alii, ed. Methods of Soil Analysis. Part 2. Madison, American Socie ty of Agronomy, p.978. (Agronomy series,9) .

MCLEAN, E.O., M.R. HEDDLESON e G.J. POST, 1959. Aluminum in soils: III - A comparison of extraction methods in soils and clays. Proceedings Soil Science Society American, Ma dison, $23(2): 289-93$.

MCLEAN, E.O., w.R. HOURIGAN, H.E. SHOEMAKER e D.R. BHUMBLA, 1964. Aluninum in soils: V - Form of aluminum as a cause of soil acidity and a composition in its measurement. Soil Science, Baltimore, $97(2): 119-26$.

MEYER, T.A. e M.W. VOLK, 1952. Effect of particle size of li mestone on reaction, exchangeable cations and plant growth. Soil Science, Baltimore, 97(2):119-26.

MIELNICZUK, J. A. LUDWICK e H. BOHNEN, 1971 . Recomendações de adubo e calcário para os solos e culturas do Rio Grande do suz. 2a. ed. Porto Alegre, UFRGS, Faculdade de Agrono mia, 40p. (Boletim Técnico, 2). 
MOHR, W., 1960. A influência da acidez sobre a fertilidade dos solos. In: 18 Congresso Nacional de Conservaçäo dos Solos, Campinas, 25p.

MUZZILI, O., R.E. KALCKMANN, F.G. MUNHOZ, 1969. Estudo da con servação da acidez dos solos do Estado do Paranā. I. Determi nação de curvas de neutralização em latossolos roxo do oeste. Revista da Escola de Agronomia e Veterinäria da Universidade Federal do Paraná, Curitiba, $\underline{5}: 25-33$.

RAGLAND, J.L. e N.T. COLEMAN, 1960. The hydrolysis of alumi num salts in clays and soils sistems. Proceedings Soil Sci ence Society American, Madison, 24 (4):457-60.

RAIJ, B. VAN., 1977. Estudo de materiais calcários usados como corretivos do solo no Estado de São Paulo. IV - o poder rela tivo de neutralização total. Bragantia, Campinas, 36. (12): $139-45$.

REEVE, N.G. e M.E. SUMNER, 1970. Lime requirement of Natal exi. sol based on exchangeable aluminum. Proceedings Soil scien ce Society American, Madison, 34(4):595-8.

SANTANA, M.B.M., 1970. Nova orientação sobre o emprego de cal cário em solos com altos níveis de alumínio, cálcio e magné sio. Itabuna, Centro de Pesquisas do Cacau. 7p.

SHAW, W.M. e B. ROBINSON, 1960. Reaction efficiences of liming materials as indicated by lisimeter leachate composition. Soir Science, Baltimore, 89: 209-18.

SOUZA, E.A. e A.M.L. NEPTUNE, 1979. Efeitos da granulometria de calcário dolomítico sobre as propriedades químicas de um la 
tossolo. Revista Erasizeira de Ciência do Solo, Campinas, 3: $120-25$.

SOUZA, E.A., 1970. Resposta das culturas da mamoneira, do mi Iho e da soja à adubação e calagem, e efeitos da calagem so bre algumas propriedades químicas em Latossol Vermelho Escu ro - fase arenosa. Jaboticabal, FCAVJ/UNESP, 90 p. (Tese de Doutoramento).

TEDESCO, M.J. e I. ANGHINONI, 1980. Efetividade da superfície específica de partículas de calcārio na correção da acidez do solo. I. Avaliação de Laboratōrio. Porto Alegre, UFRGS, Departamento de Solos. 12p. (Pesquisa em Andamento). THOMAS, G.W., 1960. Forms of aluminum in cation exchangers. In: 7. International Congress of Soil Science, Madison, v.2., 47:364-69.

TISDALE, S.L. e NELSON,W.L. 1960. Soil and Fertilizer. The MacMillan Co., New York, 694 p.

VERLENGIA, L. e H. GARGANTINI, 1972. Estudo sobre a eficiência de diferentes frações granulométricas de calcário no solo. Bragantia, Campinas, 31:il9-28.

VETTORI, L., 1969. Métodos de Análise de Solo. Rio de Janei ro, Ministério da Agricultura, Equipe de Pedologia e Fertili dade do solo. 24p. (Boletim Técnico no 7).

VIDOR, C., 1972. Toxidez de alumínio e manganês e suas rela çōes com a nodulação, rendimento e absorçäo de manganês por Glycine $\max$ (L) Merril. Porto Alegre, UFRGS, Faculdade de 
Agronomia. 7lp. (Tese de Mestrado). VOLKWEISS, S.J., 1970. Influência do calcário no pH, alumínio, manganēs e zinco de solos do Rio Grande do Sul e suas rela çōes com o rendimento e absorção de manganês e zinco pelo mi. 1ho. Porto Alegre, UFRGS, Faculdade de Agronomia. 92p. (Te se de Mestrado).

WHITE, R.P., 1970. Effects of lime upon soil and plant manga nese levels in acid soils. Proceedings Soil Science Socie ty American, Madison, 34 (4): 62-9.

WUNSCHE, W.A. e H. BOHNEN, 1976. Avaliação da dissolução de vā rias fraçōes de calcārio dolomítico no oxisol do Rio Grande do Sul. Agronomia Sulriograndense, Porto Alegre, 12:173-78. WUTKE, A.C.P. e H. GARGANTINI, 1962. Avaliação das possibilidą des de escórias de siderurgia como corretivos da acidez do solo. Bragantia, Campinas, 21:795-805.

YUAN, T.L., 1963. Some relationships among hydrogen, aluminum and $\mathrm{pH}$ in solution and soil systems. Soil Science, Baltimo re, $95(3): 155-63$. 